\title{
Species review of the genus Gnypeta Thomson from Canada, Alaska and Greenland (Coleoptera, Staphylinidae, Aleocharinae): systematics, bionomics and distribution
}

\author{
Jan Klimaszewski ${ }^{1, \dagger}$, Karine Savard ${ }^{1, \ddagger}$, Georges Pelletier ${ }^{1, \S}$, Reginald Webster ${ }^{2,1}$
}

I Natural Resources Canada, Canadian Forest Service, Laurentian Forestry Centre, Quebec, QC, Canada 224 Millstream Drive, Fredericton, NB, Canada

† urn:lsid:zoobank.org:author:75880C14-430B-45F6-8B6D-840428F3FF37

¥ urn:lsid:zoobank.org:author:716D03A0-DF55-4A60-AA54-DF4C0F4A8E7E

§ urn:lsid:zoobank.org:author:0C697BAB-5B2F-4D06-B41B-34B1C136EDDC

| urn:lsid:zoobank.org:author:DFDA5F1A-86C7-4107-8620-892181238224

Corresponding author: Jan Klimaszewski (jan.klimaszewski@nrcan.gc.ca)

Academic editor: Volker Assing | Received 30 April 2008 | Accepted 29 June 2008 | Published 4 September 2008

urn:lsid:zoobank.org:pub:664C49F1-5384-43C4-8BF1-CE76AC11D32E

Citation: Klimaszewski J, Savard K, Pelletier G, Webster R (2008) Species review of the genus Gnypeta Thomson from Canada, Alaska and Greenland (Coleoptera, Staphylinidae, Aleocharinae): systematics, bionomics and distribution. In: Majka CG, Klimaszewski J (Eds) Biodiversity, Biosystematics, and Ecology of Canadian Coleoptera. ZooKeys 2: 11-84. doi: $10.3897 /$ zookeys.2.4

\begin{abstract}
A review of the rove beetle species of the genus Gnypeta Thomson from Canada, Alaska and Greenland is presented. Eighteen species are reported from Canada of which 6 are described as new to science, 3 species described from the Palaearctic region are reported in North America for the first time: G. brincki Palm, $G$. carbonaria (Mannerheim), G. sellmani Brundin; 5 species, G. atrolucens Casey, G. crebrepunctata (Casey), G. groenlandica Lohse, G. nigrella (LeConte), G. uteana (Casey), represent new distribution records for Canada, and one, G. caerulea (C.R. Sahlberg), represents a new province and territory record. New species are: G. ashei Klimaszewski, sp. nov., G. dentata Klimaszewski, sp. nov., G. lohsei Klimaszewski sp. nov.; $G$. minuta Klimaszewski \& Webster, sp. nov., G. canadensis Klimaszewski, sp. nov., and G. saccharina Klimaszewski \& Webster, sp. nov. The lectotypes are here designated for the following species from the syntype series: Gnypeta atrolucens Casey, G. baltifera (LeConte), G. bockiana Casey, G. brevicollis Casey, G. boulderensis Casey, G. brunnescens Casey, G. crebrepunctata (Casey), G. manitobae Casey, G. nigrella (LeConte), G. oblata Casey, G. punctatula Casey, G. uteana (Casey), and G. wickhami Casey. The following new synonyms are established (first name being valid): $G$. uteana Casey ( $=G$. boulderensis Casey, $=G$. punctatula Casey), $G$. crebrepunctata Casey (= G. oblata Casey), and G. laticollis Casey ( $=$ G. wickhami Casey). The species are classified into five new species groups reflecting their presumed relationships. All treated species are illustrated,
\end{abstract}

Copyright Her Majesty the Queen in Right of Canada. This is an open access article distributed under the terms of the Creative Commons Attribution License, which permits unrestricted use, distribution, and reproduction in any medium, provided the original author and source are credited. 
and distribution maps are provided. New data on collection, habitat, and distribution are presented. A key to the identification of Canadian and Alaskan species is provided.

\section{Keywords}

Coleoptera, Aleocharinae, Gnypeta, Nearctic, taxonomy

\section{Introduction}

Paśnik (2002) reported that the genus Gnypeta Thomson contains more than 70 species distributed throughout all zoogeographical regions. Our estimate indicates that there are at least 113 nominal species in the world fauna. Seevers (1978) considered the genus Gnypeta to be widespread. Thirty-five valid species of the genus are recognized in the Palaearctic region (Smetana 2004), 40 nominal species in the Nearctic region with two additional species described from Mexico (Ashe 2001), 11 in the Neotropical region, 27 species in the Oriental region (Pasnik 2002), and a few scattered species are known from Africa. Eighteen species are here reported from Canada, Alaska and Greenland. Before this review was published, the Canadian species of Gnypeta were very poorly known and practically unidentifiable. In recent catalogues, 3 species, G. brevicornis Casey, G. caerulea (C.R. Sahlberg), and G. manitobae Casey, were listed from Canada (Campbell and Davies 1991; Gouix and Klimaszewski 2007). The knowledge on this group in Canada and all of North America consisted of scattered original descriptions (Casey 1886, 1906, 1910, 1911; LeConte 1863; Bland 1865). These papers were lacking any external or genital illustrations and had limited value for species identification. The present treatment is the first published document reviewing all Canadian, Alaskan and Greenlandian species of the genus. We provide here detailed diagnoses and descriptions of the species concerned, external and genital images, new data on relationships, collection, habitat and distribution.

Many of the Nearctic Gnypeta species have a broad and not localized distribution as assumed by Casey $(1886,1906,1910,1911)$. Four of the Canadian species are Holarctic and circumpolar in distribution (G. brincki, G. caerulea, G. carbonaria, G. sellmani); 3 species are transcontinental in northern Canada (G. groenlandica, G. ashei, $G$. dentata), 7 species are known only east of the Rocky Mountains (G. saccharina, $G$. atrolucens, G. manitobae, G. nigrella, G. canadensis, G. uteana, G. minuta), and 4 are western in distribution (G. brevicornis, G. crebrepunctata, G. helenae, G. lohsei).

A revision of the Nearctic Gnypeta was initiated about two decades ago by the late S. Ashe (University of Kansas, U.S.A.), and a review of Canadian species of Gnypeta was advanced by the late G.A. Lohse (Hamburg, Germany). However, neither of them was able to complete and publish their findings. This review includes all the material studied by them from Canada, Alaska and Greenland. Some of Ashe's "new species" (manuscript names) represent misidentifications of species previously described from the Palaearctic region but occurring in North America (e.g., G. brincki, G. sellmani), and some species designated by G.A. Lohse as new were also misidentified. All corrections are included in the present review and are discussed in the comments sections under the relevant species. 


\section{Material examined}

Over 1000 adult specimens of Gnypeta from Canada, Greenland, Alaska, and some other American states were examined. These include non-type specimens of Nearctic species, type specimens of nominal species described from North America (Casey 1886, 1906, 1910, 1911), and some Palaearctic species recently discovered in North America (Muona 1984). Almost all specimens were dissected. The genital structures were dehydrated in absolute alcohol, transferred to xylene, mounted in Canada balsam on celluloid microslides and pinned with the specimens from which they originated. The external images of adults and the genital structures were obtained from an image processing system (Nikon SMZ1500 microscope, Nikon DXM 1200F digital camera, computer with Nikon View 5, Adobe Photoshop and CombineZ5 software). The habitus images were generated by taking photos of separate images of the antenna, head, pronotum, elytra and abdomen in the horizontal plane and then enhancing these structures in Adobe Photoshop and assembling them. Unfortunately we were not able to cut contours of all individual setae outside external body outlines and therefore the setae protruding outside the body lateral margin are not shown.

Terminology mainly follows that used by Seevers (1978), Klimaszewski (1984), and Ashe (2001). The ventral part of the median lobe of the aedeagus is considered that which bears the foramen mediale of the bulbus (exit for the ductus ejaculatorius from the median lobe), and the opposite side bearing the compressor plate is considered as the dorsal part.

The following general references were used for the studied taxa (some not mentioned further in the text except for the reference list): Casey 1886, 1906, 1910, 1911; Downie and Arnett 1996 Lohse 1974; Seevers 1978; Moore and Legner 1975; and Paśnik 2006 a, b.

Eight lectotypes were here designated for the following species: Gnypeta atrolucens Casey, G. bockiana Casey, G. baltifera (LeConte); G. brevicollis Casey, G. crebrepunctata (Casey), G. manitobae Casey, G. nigrella (LeConte); and G. uteana (Casey). These species were described from syntypes and without holotype designation in the original descriptions.

The holotypes/type material of the Gnypeta species described from Europe ( $G$. brincki, G. caerulea, G. carbonaria, G. sellmani) have not been examined because these species are well documented, including illustrations, and the concept of these species is well established. However, we have compared the specimens of these species from Europe and Canada for confirmation of their status.

All genital images in this publication range in size from 0.2 to $0.4 \mathrm{~mm}$.

All the species groups proposed in this publication are new.

\section{Conventions}

Authorship of new taxa. Authorship of the new taxa is attributed to the senior author alone, unless specified otherwise. 
Localities and specimen data. All information relating to primary types is provided under each species, except for the long lists of paratypes of new species. These are listed together with the non-type material in Appendix A. Canadian localities are listed under province or territory. Additional data on specimens examined from Greenland and the United States, particularly from Alaska, are included in Appendix A whenever appropriate.

\section{Repository abbreviations:}

CBU Cape Breton University, Sydney, Nova Scotia, Canada

CGMC Christopher G. Majka collection, Halifax, Nova Scotia, Canada

CNC Canadian National Collection of Insects, Agriculture and Agri-Food Canada, Ottawa, Ontario, Canada

GGC Gösta Gillerfors private collection, Varberg, Sweden

LFC Natural Resources Canada, Canadian Forest Service, Laurentian Forestry Centre, Quebec City, Quebec, Canada

LUC Lund University Collection, Lund, Sweden

MCZ Museum of Comparative Zoology, Harvard University, Cambridge, Massachusetts, USA

MZL Museum of Zoology, Lund University, Lund, Sweden

NSM Nova Scotia Museum of Natural History, Halifax, Nova Scotia, Canada

RWC Reginald Webster collection, Fredericton, New Brunswick, Canada

USNM United States National Museum, Washington, D.C., USA

\section{Systematics}

\section{Tribe Oxypodini Thomson, 1859}

Oxypodides Thomson 1859: 36 (ICZN, 1957: Name No. 150). Oxypodini: Seevers 1978: 14; Newton and Thayer 1992: 53; Ashe 2001: 360; Klimaszewski and Winchester 2002: 54; Klimaszewski and Pelletier 2004: 447; Klimaszewski et al. 2005: 9. Type genus: Oxypoda Mannerheim 1830: 69 (ICZN, 1957: Name No. 1078).

\section{Diagnosis}

Adults. Structurally diverse group of aleocharine beetles that may be recognized by the following combination of characters: tarsal formula usually 5-5-5 but in some taxa 4-5-5 or 4-4-4, mouthparts generalized, mesocoxae moderately to narrowly separated and with slender and often sharply pointed mesoventral process; acetabula usually margined; pronotal hypomera not visible laterally in some genera (e.g. Oxypoda and close allies); abdominal tergite 9 narrowly subdivided at base (Seevers 1978); median lobe of aedeagus with an elongate compressor plate and without an "athetine bridge" (Seevers 1978); paramerite usually with elongate apical lobe and striated velum. There are 48 
genera in 5 subtribes in North America (Ashe 2001) and 24 genera in 3 subtribes in Canada and Alaska (Gouix and Klimaszewski 2007).

At the present time the placement of the genus Gnypeta in the tribe Oxypodini should be considered as a tentative arrangement due to existing controversy between different authors and the lack of comprehensive analysis at the tribal level (see discussion under Phylogenetic affiliations).

\section{Genus Gnypeta Thomson}

urn:lsid:zoobank.org:act:8297AF32-F721-495A-9B8B-97726265E3DE

Gnypeta Thomson 1858: 33; Moore and Legner 1975: 421; Seevers 1978: 83; Blackwelder 1952: 173; Ashe 2001: 363; Smetana 2004: 489. Type species: Homalota labilis Erichson 1839 (=Bolitochara carbonaria Mannerheim 1830).

Euliusa Casey 1906: 215; Moore and Legner 1975: 421; Seevers 1978: 83; Ashe 2001:

363; Smetana 2004: 489. Synonymized by Blackwelder 1952: 173. Type species: Gnypeta lucens Bernhauer 1905.

Gnypetoma Casey 1906: 196; Moore and Legner 1975: 421; Seevers 1978: 83; Ashe 2001: 363; Smetana 2004: 489. Synonymized by Blackwelder 1952: 173. Type species: Tachyusa baltifera LeConte 1863.

\section{Diagnosis}

Members of this genus may be distinguished by the following combination of characters: tarsi 4, 5, 5-articulated (Figs 1, 2); body medium sized, length 2.3-3.6 mm, moderately to strongly glossy, integument finely punctate and pubescent, pubescence moderately long and often silky in appearance; head and pronotum distinctly narrower than elytra (Figs 1-20); abdomen as broad as elytra at base or moderately narrower (Figs 1-20), subparallel (Figs 3-7), or broadening apically (Figs 9, 18 20), first three visible tergites with deep basal impressions bearing coarse punctures but without pronounced longitudinal ridges (Fig. 1); postgenal carinae incomplete or absent (Seevers 1978); pronotum broadest in apical third or in the middle of the disc, and converging apically and basally (Fig. 1), pubescence distributed postero-laterad from the midline of the disc (Figs 1-20); elytra much broader than both head or pronotum, and often with wavy pubescence pattern on both sides (Figs 1-20); mesoventral process moderately broad, attaining middle of mesocoxae, its apex truncate (Fig. 2); metaventral process broadly rounded (Fig. 2); first visible three tergites with deep basal impressions bearing coarse punctures; legs long and slender; basal article of metatarsus moderately elongate and usually shorter than the two following articles combined (Fig. 1). GENITAL STRUCTURES: median lobe of aedeagus consists of an enlarged, swollen bulbus and short, triangularly produced tubus (Figs 40, 41, 49, 58, 67, 68, 76, 84, 92, 100, $109,110,118,131,132,140,141,149,157,165,173,182)$, crista apicalis of bulbus large and subtriangular in shape laterally (Figs 39, 48, 57, 56); paramere broad with short apical lobe bearing three long subapical and one short apical macrosetae (Figs 60, $77,85,119,142,150)$; male tergite 8 truncate, or rarely emarginated apically, its apical 


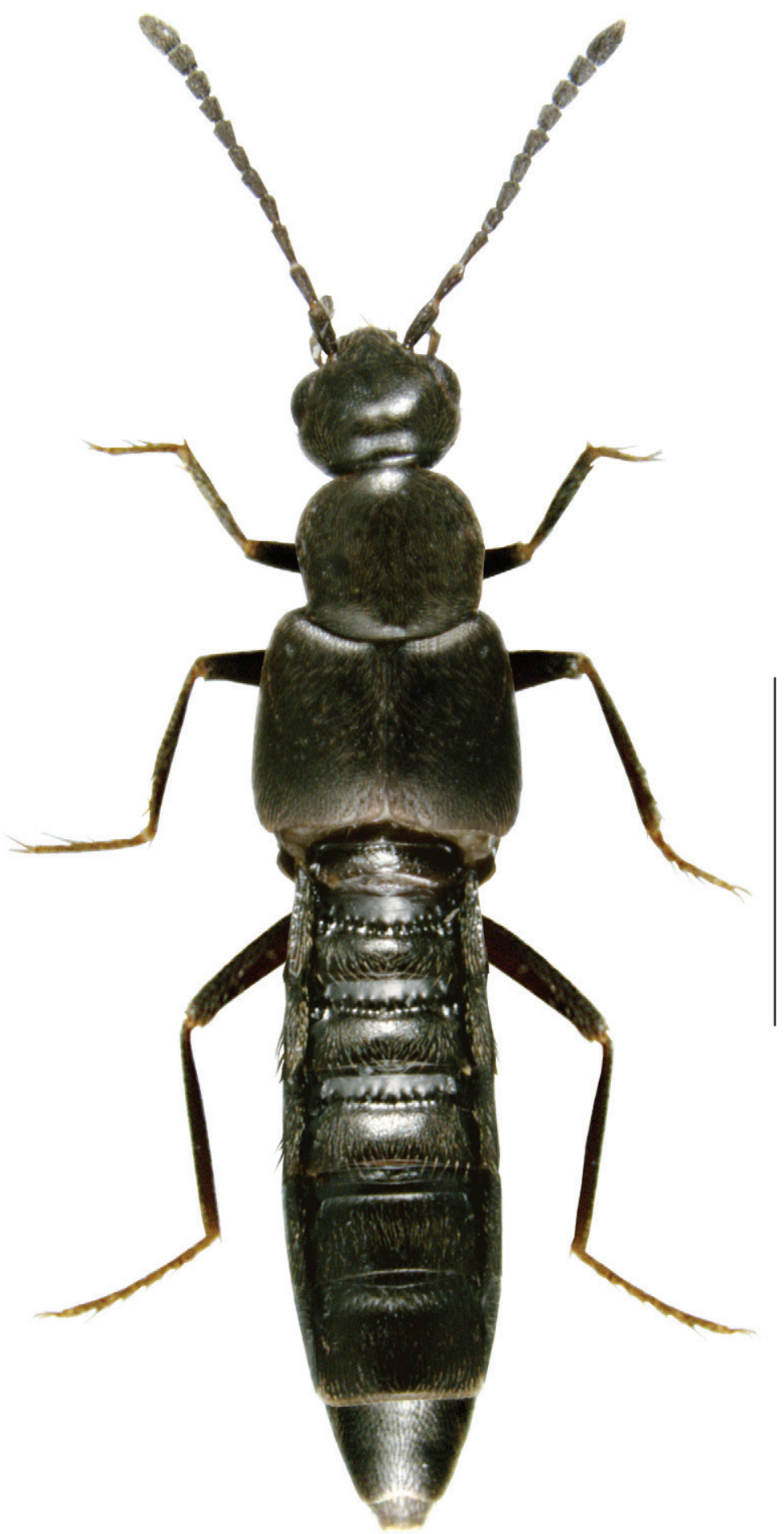

Fig. I. Gnypeta nigrella (LeConte), in dorsal view. Scale $=1 \mathrm{~mm}$. 


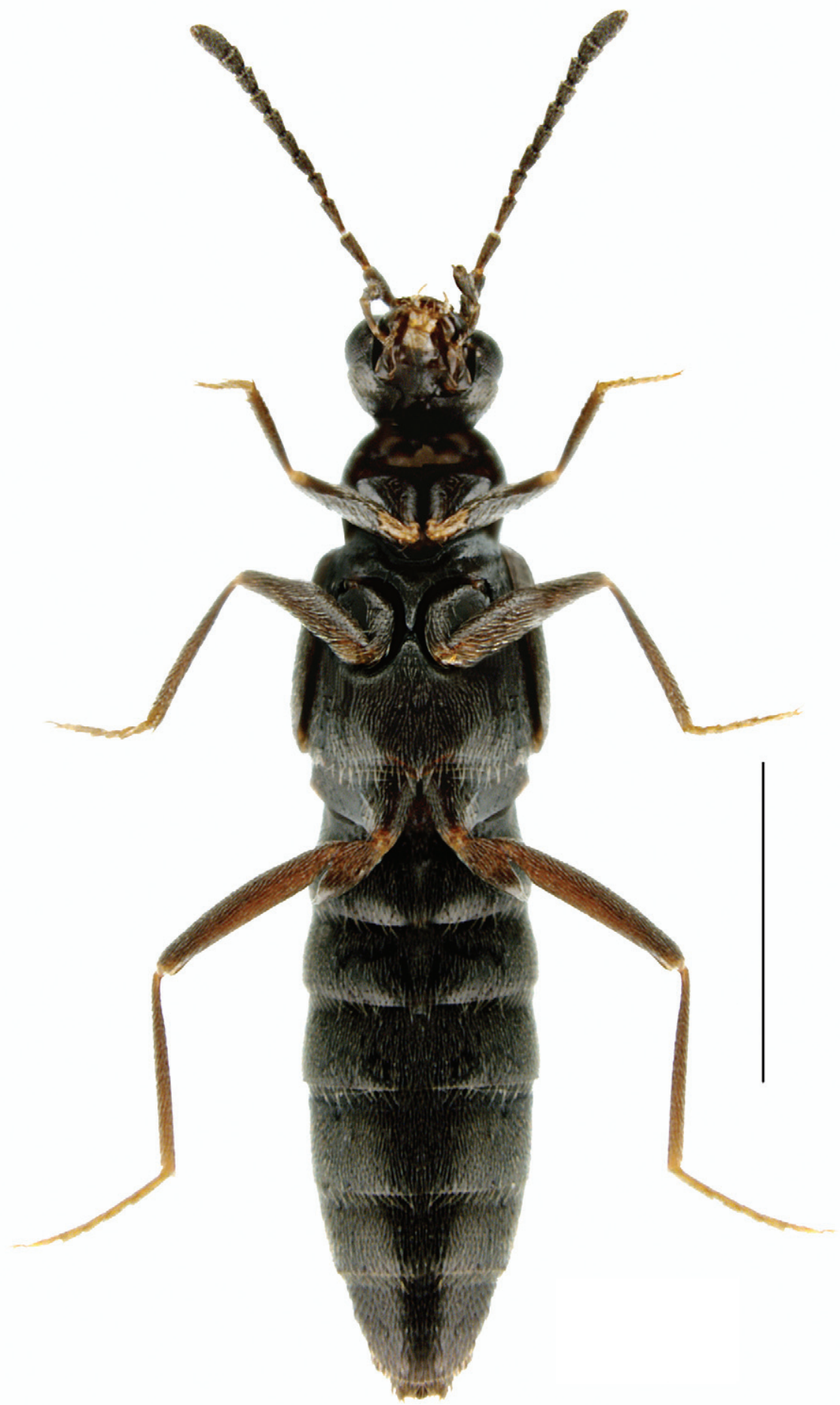

Fig. 2. Gnypeta nigrella (LeConte), in ventral view. Scale $=1 \mathrm{~mm}$. 
margin smooth or with small 2-4 dents (Figs 43, 52, 61, 78, 103, 112, 167); spermatheca of four types: S-shaped (Figs 105, 114, 153, 161), C-shaped (Figs 122, 127-129, 136), hatchet-shaped (Figs 45, 54, 63, 72, 80, 88, 96), or club-shaped (Figs 169, 178, 186, 187); capsule tubular with apical part approximately spherical (Figs 145, 169, 178, 186, 187), tubular (Figs 122, 127,153, 161), or funnel-shaped (Figs 45, 54, $63,72)$; stem tubular, elongate, more or less sinuate and moderately swollen basally.

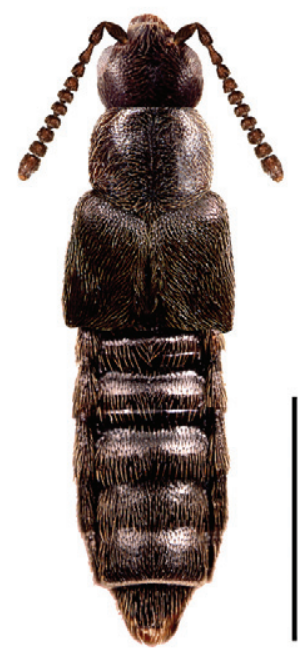

3

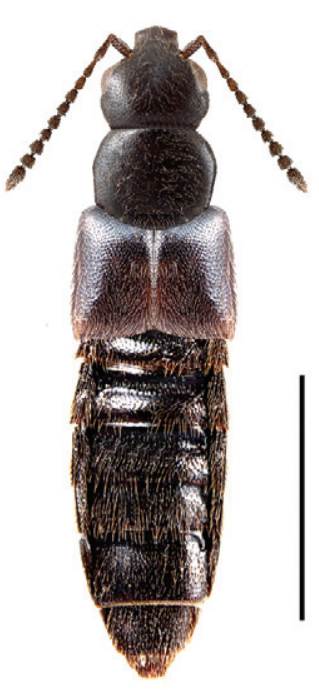

6

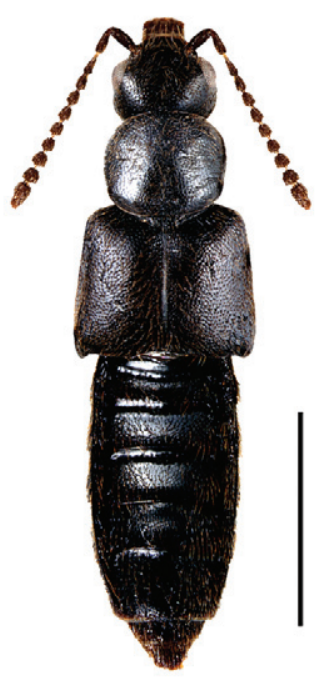

4

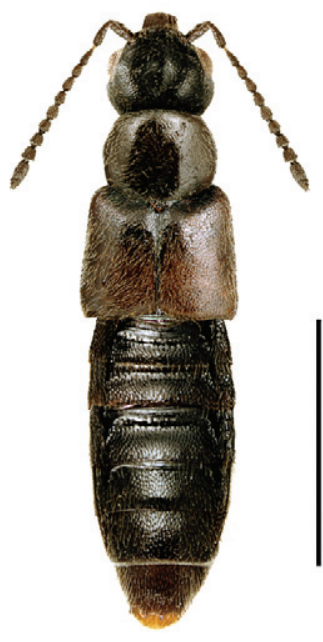

7

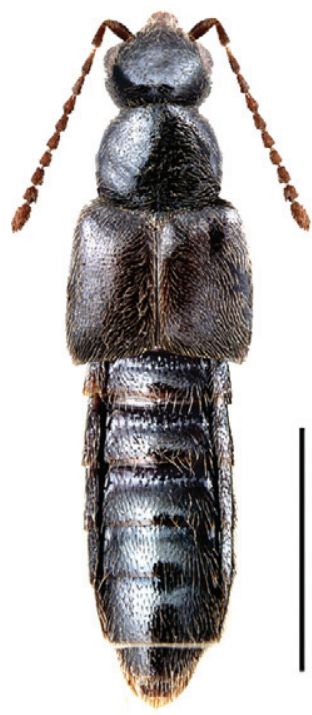

5

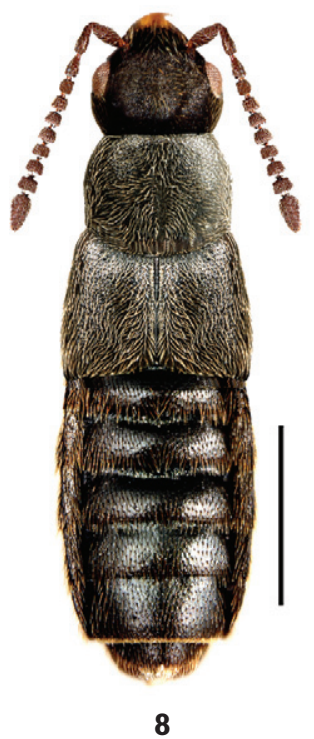

Figs 3-8. Gnypeta species: 3, G. ashei; 4, G. brincki; 5, G. atrolucens; 6, G. sellmani: 7, G. dentata; and 8, G. groenlandica. Scale $=1 \mathrm{~mm}$ 
Sternite 8 of male and female with broad space between basal margin and antecostal suture (Figs 44, 47, 53, 56, 62, 65). Gnypeta is readily distinguished from most genera of Oxypodini by having 4, 5, 5-articulated tarsi and from closely related Tachyusa by robust body (slender in Tachyusa), abdomen at base as broad as elytra or only slightly narrower (much narrower in Tachyusa), lack of distinctive ridges in abdominal tergal impressions, and by less elongate basal article of metatarsus (usually shorter than the

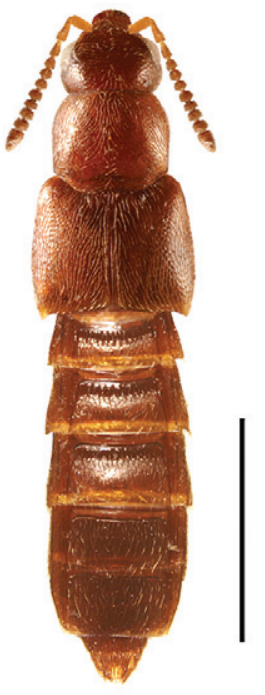

9

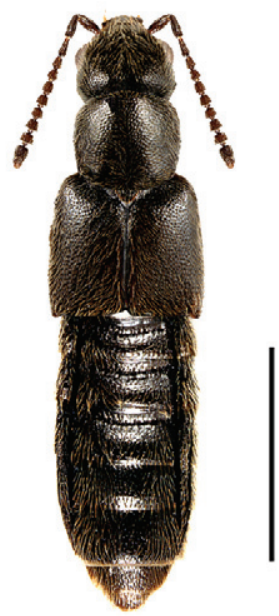

12

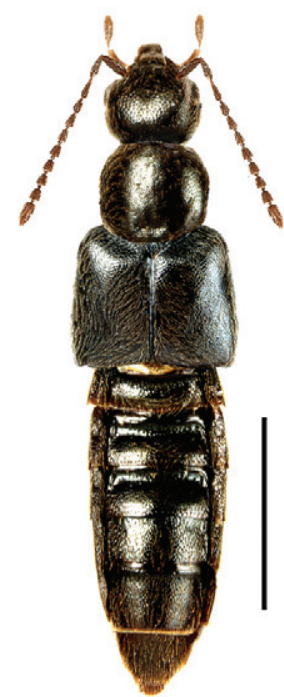

10

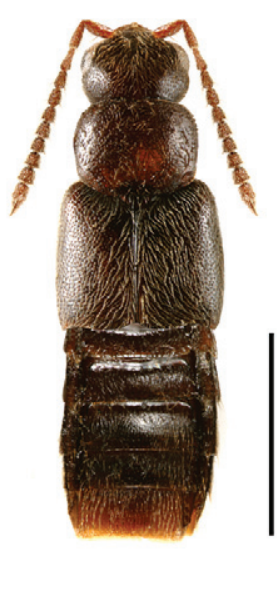

13

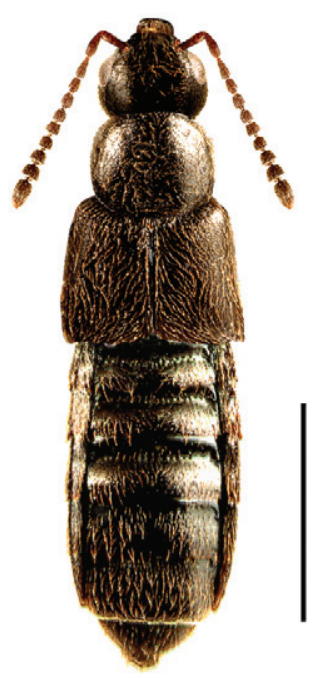

I I

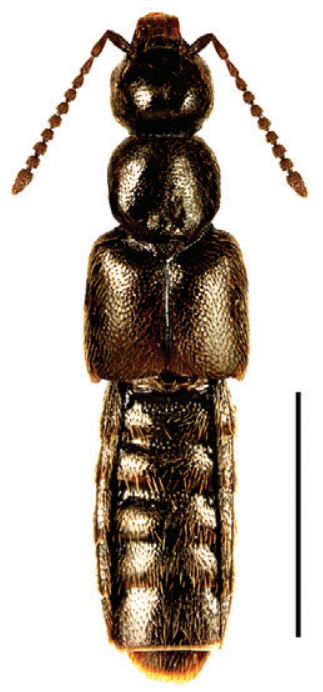

14

Figs 9-I4. Gnypeta species: 9, G. brevicornis; 10, G. caerulea; 11, G. lohsei; 12, G. crebrepunctata; $13, G$. manitobae [apical part of abdomen removed]; 14, G. uteana. Scale $=1 \mathrm{~mm}$ 
two following articles combined). Ischnopoda Stephens is another related genus to Gnypeta, which differs externally by parallel-sided body, and extremely elongate metatarsus, exceeding $4 / 5$ length of metatibia, and with basal article at least as long as the two following articles combined (Fig. 1). According to Paśnik (2007) the genus Gnypeta is closely related to Tachyusa, Ischnopoderona (Scheerpeltz) and Ischnopoda. The key for these four genera is provided by Paśnik (2007).

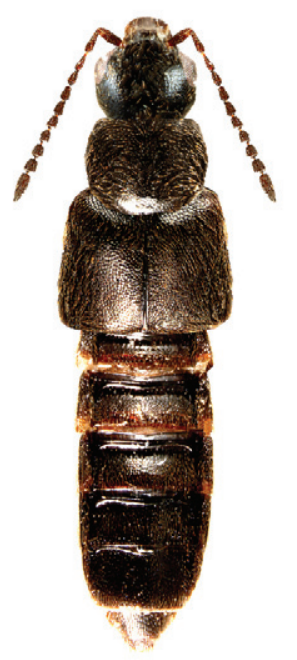

15

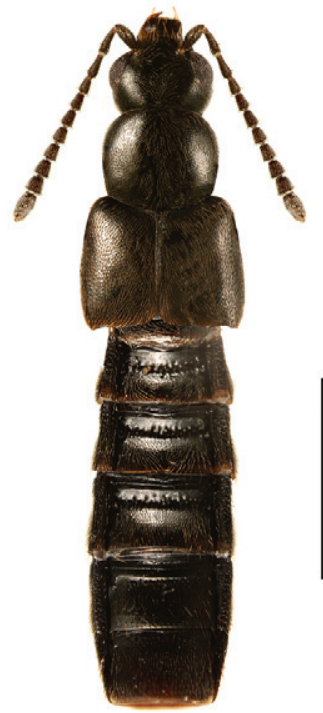

18

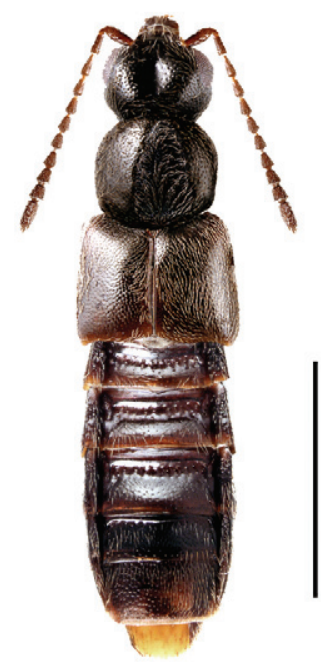

16

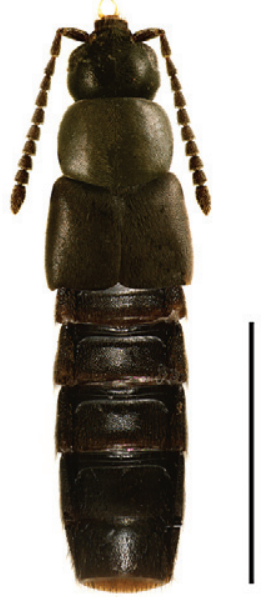

19

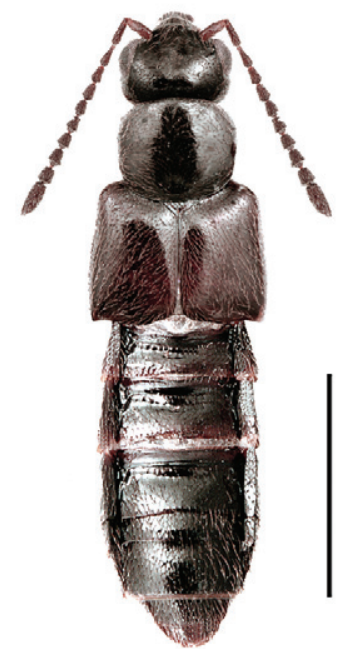

17

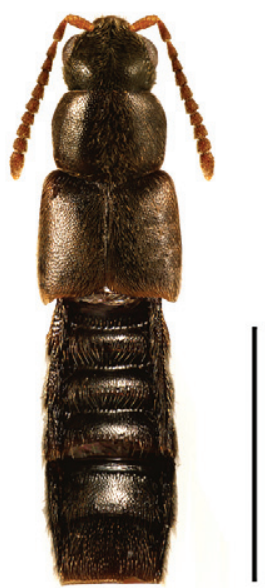

20

Figs I5-20. Gnypeta species: 15, G. carbonaria; 16, G. helenae; 17, G. canadensis; 18, G. nigrella; $19, G$. saccharina; and 20, G. minuta [18-20, apical part of abdomen removed]. Scale = $1 \mathrm{~mm}$ 

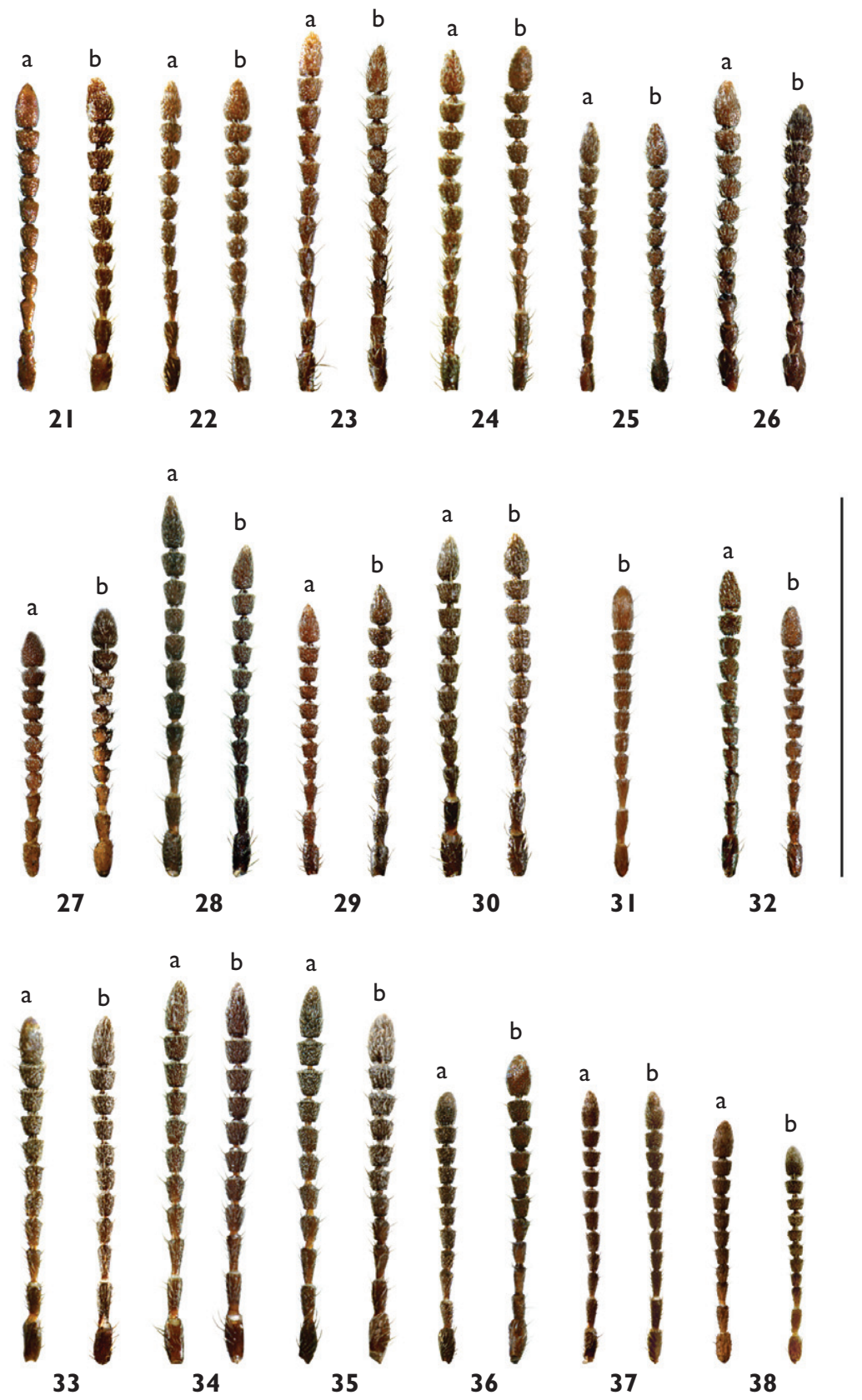

Figs 2 I-38. Antennae of Gnypeta species: G. ashei: 21a. male, 21b. female; G. brincki: 22a. male, 22b. female; G. atrolucens: 23a. male, 23b. female; G. sellmani: 24a. male, 24b. female; G. dentata: 25a. male, 25b. female; G. groenlandica: 26a. male, 26b. female: G. brevicornis: 27a. male, 27b. female; G. caerulea: 28a. male, 28b. female; G. lohsei: 29a. male, 29b. female; G. crebrepunctata: 30a. male, 30b. female; $G$. manitobae: 31b. female; G. uteana: 32a. male, 32b. female; G. carbonaria: 33a. male, 33b. female; $G$. helenae: 34a. male, 34b. female; G. canadensis: 35a. male, 35b. female; G. nigrella: 36a. male, 36b. female; G. saccharina: 37a. male, 37b. female; G. minuta: 38 a. male, 38b. female. Scale $=1 \mathrm{~mm}$ 


\section{Collection and habitat data}

Adults are associated with riparian habitats and debris along the margins of marshes, ponds, lakes, and streams (Ashe 2001). Some Canadian species were found in cold wet moss alongside streams. They may also occur in vegetation and litter along edges of streams, river, and lakes, in grass tussocks on mud flats, in gravel, wooded bogs, beaver lodges, and decaying fungi.

\section{Phylogenetic affiliations}

Seevers (1978) classified the genus Gnypeta in the tribe Oxypodini and the subtribe Tachyusae (=Tachyusina Thomson), together with the genera Tachyusa Erichson, Trachyota Casey, Teliusa Casey, Gnypetella Casey, Meronera Sharp, and Brachyusa Mulsant and Rey. He was tempted to consider Tachyusae as a distinct tribe on the grounds of 4, 5,5-articulated tarsi and the genital features but he was afraid that this arrangement would obscure the relationship of Gnypeta to some related oxypodine genera. Bernhauer and Scheerpeltz (1926) did not separate genera of Tachyusina from Falagriini and grouped them together in the subtribe Falagriae of the tribe Myrmedoniini Ganglbauer. Lohse (1974) placed Gnypeta together with Falagria Leach, Cordalia Jacobs, Myrmecopora Saulcy and allied genera of the Falagriini. We agree with Seevers (1978) that grouping Tachyusae and Falagriae together, mainly on the grounds of 4, 5, 5-articulated tarsi and some superficial external similarities, was artificial and unwarranted. According to Seevers (1978) and confirmed here by us, the Tachyusae lack the following specialized features of the Falagriini: paramere with codylite velum separated from the paramerite velum; pronotum much narrower at base than apex and with distinct (at least one) median sulcus (sometimes two lateral sulci present); peritremes enlarged, and contiguous with or fused to elongate prosternum; procoxal cavities closed by peritremes, prosternum and inflexed hypomera. In addition the Falagriini have a basal abdominal impression bearing a median ridge, a very distinct shape of the median lobe of the aedeagus (ovoid bulbus and tubular broad tubus), small and narrowly elongate crista apicalis of bulbus, extremely long and coiled flagellum of the internal sac of the median lobe, and the spermatheca is of a different type with a small spherical capsule connected to a thin stem (Figs 165, 166, 169 in Klimaszewski and Winchester 2002). For diagnostic features of Tachyusina, see Seevers (1978). In his worldwide treatment of Ischnopoda Stephens, Paśnik (2006b) considered this genus to be closely related to Tachyusa and Gnypeta. Based on a comparative study of mouthparts and the body chaetotaxy, Yosii and Sawada (1976) suggested a restricted concept of Tachyusa-related genera and placed Tachyusa together with Gnypeta, and Dacrila Mulsant and Rey in the Tachyusa series of the Athetae. Their tribal affiliation of the Tachyusa-related genera with athetines is strongly questionable because of the differences in the genital features of the two groups e.g., lack of the "athetine bridge" in the median lobe of the aedeagus in genera of Tachyusini. Lohse (1989) excluded Tachyusa, Gnypeta, and Dasygnypeta Lohse from Falagriini and transferred them together with Brachyusa and Dacrila to the separate tribe Tachyusini. Paśnik (2006b), in his revision of the world species of Tachyusa, did not provide his view on the higher classification of Tachyusa-related genera but did not contradict 
the classification proposed by Lohse (1989). Paśnik (2007) published a revision of the African genus Ischnopoderona (Scheerpeltz), with cladistic analysis of the species. He included there the outgroup taxa of the genera Gnypeta, Ischnopoda, and Tachyusa. On his single most parsimonious cladogram the Ischnopoderona branched off as a sisiter taxon of Tachyusa and both of them combined formed a sister taxon of Gnypeta. The Ischnopoderona was the most basal branch of this tree. We believe that more research is needed before tribal classification of this group becomes clear and stable.

\section{Checklist of Gnypeta species occurring in Canada, Alaska and Greenland}

Conventions. Junior synonyms are indented. Some United States records, particularly from the states bordering Canada, are also included. The countries, states and provinces in bold represent new records. Species names are followed by the author only in the case of the new species described here and by the author with the original and some subsequent reference data for the species already described.

\section{Review of Canadian, Alaskan and Greenlandian species}

\section{Gnypeta sellmani species group}

1. Gnypeta ashei Klimaszewski sp. nov. (CANADA: Manitoba, Northwest Territories, Yukon Territory; UNITED STATES: Alaska).

2. Gnypeta brincki Palm 1966: 139; Smetana 2004: 489. (CANADA: Quebec, Yukon Territory, Northwest Territories; UNITED STATES: Alaska; EUROPE: Finland, Norway, Sweden).

3. Gnypeta atrolucens Casey 1894: 346, 1906: 197; Moore and Legner 1975: 421 (CANADA: Newfoundland, Quebec; UNITED STATES: New Hampshire, New York, Vermont).

4. Gnypeta sellmani Brundin 1929: 14; Palm 1966: 139; Smetana 2004: 490. (CANADA: Quebec, Manitoba, Saskatchewan, Yukon Territory, Northwest Territories; UNITED STATES: Alaska; EUROPE: Finland, Norway, Sweden, Russia).

5. Gnypeta dentata Klimaszewski sp. nov. (CANADA: Saskatchewan, Alberta, Northwest Territories).

6. Gnypeta groenlandica Lohse 1989: 58 (CANADA: Manitoba, Northwest Territories, Nunavut; UNITED STATES: Alaska; GREENLAND).

7. Gnypeta brevicornis Casey 1906: 196; Moore and Legner 1975: 421. (CANADA: British Columbia).

\section{Gnypeta caerulea species group}

8. Gnypeta caerulea (C.R. Sahlberg 1830:351); Bernhauer and Scheerpeltz 1926: 587; Palm 1966: 138; Muona 1984: 228; Campbell and Davies 1991: 100; Smetana 2004: 489. 
(CANADA: Newfoundland, Nova Scotia, New Brunswick, Prince Edward Island, Quebec, Ontario, Manitoba, Saskatchewan, Alberta, Yukon Territory, Northwest Territories; UNITED STATES: Alaska; EUROPE, ASIA).

9. Gnypeta lohsei Klimaszewski sp. nov. (CANADA: Alberta, British Columbia; UNITED STATES: Alaska, Washington).

III. Gnypeta crebrepunctata species group

10. Gnypeta crebrepunctata (Casey 1886: 203); Casey 1906: 194; Moore and Legner 1975: 421.

(CANADA: British Columbia; UNITED STATES: California, Oregon). Gnypeta oblata Casey 1911: 168. As synonym of G. helenae: Moore and Legner 1975: 422. (UNITED STATES: California). New synonymy.

11. Gnypeta manitobae Casey 1906: 196. As G. bockiana Casey: Moore and Legner 1975: 421. (Canada, Manitoba, Winnipeg).

12. Gnypeta uteana (Casey 1911: 169); Moore and Legner 1975: 422. (CANADA: Alberta; UNITED STATES: California, Colorado, Utah).

Gnypeta boulderensis Casey 1911: 167. As synonym of G. helenae: Moore and Legner 1975: 422. (UNITED STATES: Colorado). New synonymy.

Gnypeta punctatula Casey 1906: 194. As synonym of G. helenae: Moore and Legner 1975: 422. (UNITED STATES: California). New synonymy.

13. Gnypeta carbonaria (Mannerheim 1830: 75); Smetana 2004: 489. (CANADA: New Brunswick, Quebec, Ontario, Manitoba, Saskatchewan, Alberta, Northwest Territories; UNITED STATES: Alaska; EUROPE, NORTH AFRICA, ASIA).

\section{Gnypeta helenae species group}

14. Gnypeta helenae Casey 1906: 193; Moore and Legner 1975: 422 (CANADA: Alberta, British Columbia; UNITED STATES: Arizona, Montana, Oregon). Gnypeta deserticola Casey 1906: 193. Synonymized by Moore and Legner 1975: 422. Synonymy confirmed.

Gnypeta oregona Casey 1906: 199. Synonymized by Moore and Legner 1975: 422. Synonymy confirmed.

15. Gnypeta canadensis Klimaszewski, sp. nov. (CANADA: Alberta, Ontario).

\section{Gnypeta nigrella species group}

16. Gnypeta nigrella (LeConte 1863: 29); Bland 1865: 412; Moore and Legner 1975: 422. (CANADA: New Brunswick; UNITED STATES: Massachusetts, Pennsylvania, Maryland, Vermont).

17. Gnypeta saccharina Klimaszewski and Webster, sp. nov. (CANADA: New Brunswick).

18. Gnypeta minuta Klimaszewski and Webster, sp. nov. (CANADA: New Brunswick). 


\section{Species excluded from Gnypeta}

Tachyusa harfordi Casey 1885: 304. Transferred to Gnypeta: Casey 1906: 202. Reinstated to the original combination, Tachyusa harfordi Casey (Paśnik 2006a: 118).

\section{Key to Gnypeta species occurring in Canada,Alaska and Greenland}

1. Basal article of metatarsus longer than two following articles combined......2

- Basal article of metatarsus at most as long as two following articles combined (Fig. 1).

2. Antennal articles 8-10 strongly transverse (Figs $27 \mathrm{a}, \mathrm{b}$ ); median lobe of aedeagus with narrowly triangular apical part in lateral view (Fig. 91), and bulbus with two lateral projections in dorsal view (Fig. 92); spermatheca with capsule pitcher-shaped (Fig. 96); female sternite 8 rounded apically (Fig. 98)

G. brevicornis Casey

- $\quad$ Antennal articles 8-10 quadrate or slightly elongate (Figs 32 a, b); median lobe of aedeagus with broadly triangular apical part in lateral view (Fig. 130); spermatheca C-shaped, capsule mushroom-formed (Fig. 136); female sternite 8 emarginate apically (Fig. 138)

G. uteana (Casey)

3. Body broad and robust (Fig. 8), pronotum at base about as broad as elytra (Fig. 8), abdomen swollen medially and at base as broad as elytra (Fig. 8); median lobe of aedeagus and spermatheca as illustrated (Figs 83, 84, 88) .....

G. groenlandica Lohse

- Body narrow and less robust (Figs 3, 5, 6, 9, 14, 15), pronotum at base narrower than elytra, abdomen subparallel and at base narrower than elytra (Figs 3, 7, 9-15); genitalia differently shaped.

4. Elytra at suture approximately as long as pronotum (Figs 3, 6, 7, 10, 15-19)

Elytra at suture distinctly longer than pronotum (Figs 4, 5, 11-13, 20)... 13

5. Antennal articles 7-10 strongly transverse (Figs $21 \mathrm{a}, \mathrm{b}$ ); median lobe of aedeagus and spermatheca as illustrated (Figs 39, 40, 41, 45) G. ashei sp. nov.

- $\quad$ Antennal articles 7-10 elongate, subquadrate or slightly transverse (Figs 23-25 a, b, 28 a, b, 31 b, 33-37 a, b); genitalia differently shaped (Figs 75, 76, 80, 99-101, 105, 139-141, 145, 148, 149, 153, 156, 157, 161, 164, 165, 169, 172-174, 178)....6

6. Antennal articles 7-10 slightly transverse (Figs 24 a, b, 25 a, b, 33 a, b); female sternite 8 without deep median emargination (Figs 74, 82, 147) ........7

- $\quad$ Antennal articles 7-10 elongate or subquadrate (Figs 28 a, b, 34-37 a, b); female sternite 8, except for G. caerulea, with deep apical emargination (Figs $107,155,163,171,180)$

7. Body length 3.0-3.4 mm; median lobe of the aedeagus with apical part narrowly produced (Fig. 66); spermatheca with capsule funnel-shaped and as wide as long (Fig. 72). G. sellmani Brundin 
- $\quad$ Body length 2.5-3.0 mm; median lobe of aedeagus and spermatheca differently shaped (Figs 75, 76, 80, 139-141, 145).... .. 8

8. Body length $2.5-2.7 \mathrm{~mm}$; male tergite 8 with four apical dents on apical margin (Fig. 78); spermatheca with capsule funnel-shaped (Fig. 80); median lobe of aedeagus with apical part narrowly triangular with sinuate margins (Fig. 75).

G. dentata sp. nov.

- $\quad$ Body length 2.7-3.0 mm; male tergite 8 without teeth and with minute median emargination on apical margin (Fig. 143); spermatheca with apical part of capsule approximately spherical (Fig. 145); median lobe of aedeagus with apical part moderately narrowly triangular, narrowly bottle-shaped (Fig. 139)

G. carbonaria (Mannerheim)

9. Integument moderately glossy with minute pubescence (Figs 18, 19); basal three tergal impressions virtually impunctate except for the margins of tergites (Figs 1, 18, 19); body length 2.4-3.0 mm; genitalia as in Figs 164, $165,169,172-174,178$

- $\quad$ Integument strongly glossy with pubescence moderately long (Figs 10, 16, 17); basal three tergal impressions with dispersed punctation (Figs 10, 16, 17); body length 2.7-3.5 mm; genitalia as illustrated (Figs 99-101, 105, 148, $149,153,156,157,161)$

10. Pronotum and abdomen at base distinctly narrower than elytra (Fig. 18); first three visible tergal impressions lacking coarse punctation except for the posterior margin (Fig. 1); median lobe of aedeagus with tubus swollen laterally (Fig. 164), spermatheca club-shaped (Fig. 169) G. nigrella (LeConte)

- $\quad$ Pronotum and abdomen at base slightly narrower than elytra (Fig. 19); first three visible tergal impressions with dispersed coarse punctation; genital structures differently shaped (Figs 172-174, 178) ..... G. saccharina sp. nov.

11. Body length 3.0-3.5 mm; genitalia as illustrated (Figs 99-101, 105)

G. caerulea (Sahlberg)

- $\quad$ Body length 2.5-3.0 mm; genitalia differently shaped (Figs 148, 149, 153, $156,157,161)$

12. Median lobe of aedeagus with moderately broad and slightly produced ventrally apical part (Fig. 148); spermatheca with thin stem (Fig. 153); western Canada G. belenae Casey

- Median lobe of aedeagus narrowly triangular and strongly produced ventrally (Fig. 156); spermatheca with moderately wide stem (Fig. 161); eastern Canada. G. canadensis sp. nov.

13. Antennal articles 7-10 strongly elongate (Figs $23 \mathrm{a}, \mathrm{b}$ ); median lobe of aedeagus and spermatheca as illustrated (Figs 57-59, 63)...... G. atrolucens Casey

- $\quad$ Antennal articles 7-10 subquadrate to transverse (Figs 22 a, b, 29-31 a, b, $38 \mathrm{a}, \mathrm{b}$ ); genital structures differently shaped (Figs 48-50, 54, 108-110, 114 , $117,118,122,127-129,181-182,186,187)$ 14

14. Abdomen broad, at base approximately as broad as elytra (Figs 11, 13); genital structures as illustrated (Figs 108-110, 114, 127-129). 
- $\quad$ Abdomen moderately broad, at base distinctly narrower than elytra (Figs 4, 12, 20); genital structures differently shaped (Figs 48-50, 54, 117, 118, 122, $181,182,186,187)$

15. Antennal articles 7-10 subquadrate (Fig. 31 b); spermatheca C-shaped (Figs 127-129) G. manitobae Casey Antennal articles 7-10 transverse (Figs 29 a, b); spermatheca S-shaped (Fig. 114). G. lobsei sp. nov.

16. Pronotum almost as wide as elytra (Fig. 20); punctures in abdominal impressions very coarse (Fig. 20); abdomen strongly narrowed at base (Fig. 20); genital structures as illustrated (Figs 181, 182, 186, 187)

G. minuta sp. nov.

- $\quad$ Pronotum distinctly narrower than elytra (Figs 4, 12); punctures in abdominal impressions fine or moderately coarse (Figs 4, 12); genital structures differently shaped (Figs 48-50, 54, 117, 118, 122)

17. Body small, length 2.7-3.0 mm (Fig. 12); median lobe of aedeagus with apical part narrowly produced ventrally (Fig. 117); spermatheca C-shaped, tubular (Fig. 122).

G. crebrepunctata (Casey)

- $\quad$ Body large, length 3.2-3.6 mm (Fig. 4); median lobe of aedeagus with apical part broadly triangular in lateral view (Fig. 48); spermatheca with funnel-shaped capsule and thin and sinuate stem (Fig. 54)

G. brincki Palm

\section{Gnypeta sellmani species group}

The sellmani species group may be characterized by the following combination of characters: spermatheca with pitcher-shaped capsule bearing broad invagination, and clubshaped stem (Figs 45, 54, 63, 72, 80, 88, 96); median lobe of aedeagus with short tubus, narrowly or broadly triangular in lateral view (Figs 39, 48, 57, 66, 75, 83, 91).

Species included: G. brevicornis Casey, G. ashei Klimaszewski, sp. nov., G. brincki Palm, G. atrolucens Casey, G. dentata Klimaszewski, sp. nov., G. groenlandica Lohse; and $G$. sellmani Brundin.

\section{Gnypeta ashei Klimaszewski, sp. nov.} urn:lsid:zoobank.org:act:C0AC9EAB-C95F-481E-BCD9-C3046CBEEA33 (Figs 3, 21 a, b, 39-47, 190)

HOLOTYPE (male): CANADA, Northwest Territories, Hazen Camp, Ellesmere I., [8149'00" N, 71²0'00" W] 10.VIII.1961, D.R. Olivier; paratype Gnypeta larifuga Ashe [manuscript name], det. Ashe 1987, CNC No. 23676 (CNC). PARATYPES: listed in Appendix A. 

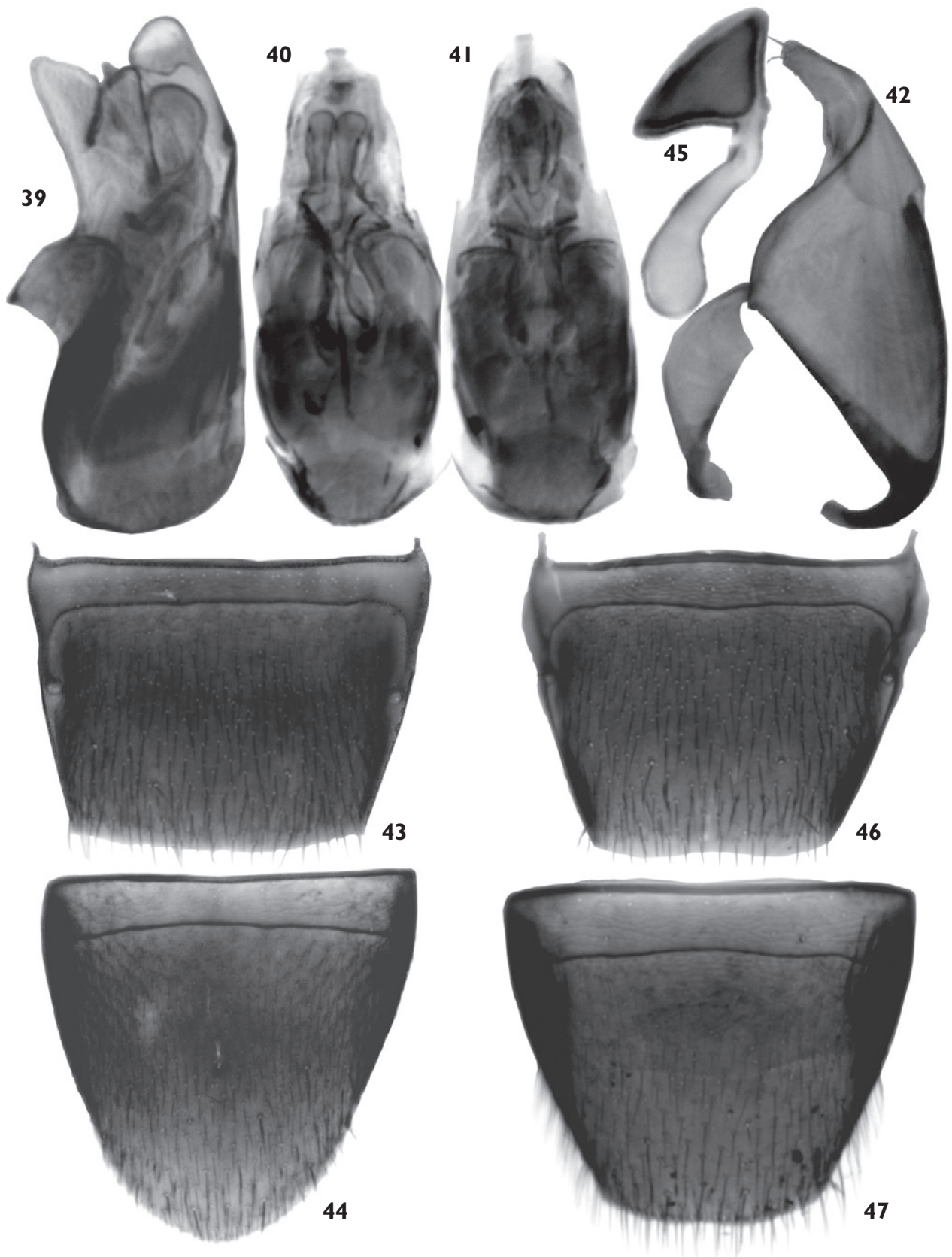

Figs 39-47. Genital structures of Gnypeta ashei: 39, median lobe of the aedeagus in lateral view, 40, dorsal view, 41 , ventral view; 42 , paramere; 43 , male tergite 8 ; 44, male sternite 8 ; 45 , spermatheca; 46 , female tergite $8 ; 47$, female sternite 8 . 


\section{Etymology}

This species is named after the late Steve Ashe of the University of Kansas who discovered this species but did not publish it. The CNC specimens, which he examined, bear his identification labels as the manuscript - unpublished name "Gnypeta larifuga Ashe".

\section{Diagnosis}

This species can be recognized by the following combination of characters: body length 2.5-2.8 mm (Fig. 3); elytra (at suture) about as long as pronotum and 1/4 wider than maximum width of pronotum (Fig. 3); abdomen at base slightly narrower than elytra (Fig. 3); antennal articles 4-6 subquadrate, and 7-9 transverse (Fig. 3); median lobe of aedeagus with apex broadly triangular (Fig. 39); spermatheca with capsule wider than long and broadly funnel-shaped (Fig. 45); stem sinuate and slightly swollen basally (Fig. 45).

\section{Description}

Body length 2.5-2.8 mm; dark brown to black, sometimes central part of elytra and tarsi reddish brown (Fig. 3); integument strongly glossy; pubescence yellowish grey and moderately long and dense; antennal article 4 slightly shorter than preceding article, articles 4-6 subquadrate to slightly elongate in male, and 7-9 transverse (Fig. 21 a, b); head and pronotum of about the same width (Fig. 3); elytra and abdomen wider than either head or pronotum; elytra small and short (Fig. 3); head rounded basally; pronotum broadest in apical third, pubescence directed anterad along midline and laterad elsewhere; elytra (at suture) about as long as pronotum and 1/4 broader than maximum width of pronotum (Fig. 3), pubescence directed obliquely postero-laterad, with wavy pattern on medial part of disc; abdomen subparallel, slightly narrower than elytra at base (Fig. 3); metatarsus with two basal articles of about the same length and the third one slightly shorter. Male. Tergite 8 transverse and truncate apically (Fig. 43). Sternite 8 about as long as wide and slightly produced posteriorly (Fig. 44). Median lobe of aedeagus with broadly triangular apical part of tubus in lateral view (Fig. 39); bulbus moderately sized (Figs 40, 41); internal sac with structures as illustrated (Figs 39-41). Female. Tergite 8 similar to that of male (Fig. 46). Sternite 8 broadly rounded posteriorly (Fig. 47). Spermatheca with capsule wider than long and broadly funnelshaped (Fig. 45), stem sinuate and swollen basally (Fig. 45).

Distribution (Fig. 190)

Gnypeta ashei is a Nearctic species recorded here from Manitoba, Yukon Territory, Northwest Territories, and Alaska.

\section{Collection and habitat data}

Adults were collected in June, July and August from marsh, by treading sedges around edge of a pond, and by sifting litter at the shore of a lagoon. One specimen was taken on snow on Devon Island. 


\section{Comments}

The late Steve Ashe (University of Kansas) worked on a revision of Nearctic Gnypeta but was not able to complete it. Some specimens of this species that he studied were returned to $\mathrm{CNC}$ with his 1987 identification labels as "G. larifuga Ashe" [manuscript name - unpublished].

\section{Gnypeta brincki Palm}

(Figs 4, 22 a, b, 48-56, 191)

TYPE LOCALITY: SWEDEN, Torne Lappmark, Abisco, 1947 (LUC). Holotype not examined.

\section{Material examined}

Specimens are listed in Appendix A.

\section{Diagnosis}

This species can be recognized by the following combination of characters: body length 3.2-3.6 mm (Fig. 4); elytra (at suture) slightly longer than pronotum and 1/3 wider than maximum width of pronotum (Fig. 4); abdomen at base distinctly narrower than elytra (Fig. 4); antennal articles 4-6 elongate in males and subquadrate in females, articles 7-9 transverse (Figs 22 a, b); median lobe of aedeagus with apical part broadly triangular in lateral view (Fig. 48); spermatheca with capsule wider than long and funnel-shaped (Fig. 54); stem sinuate and slightly swollen basally (Fig. 54).

\section{Description}

Body length 3.2-3.6 mm; black, sometimes central part of elytra and tarsi reddish brown (Fig. 4); integument strongly glossy; pubescence yellowish grey and moderately long and dense; antennal article 4 slightly shorter than preceding one, 4-6 elongate in males and subquadrate in females, articles 7-9 transverse (Figs 22 a, b); head and pronotum of about the same width, abdomen wider than either head or pronotum; elytra large and distinctly broader than remainder of body (Fig. 4); head rounded posteriorly; pronotum broadest in apical third, pubescence directed anterad along midline and laterad elsewhere; elytra (at suture) slightly longer than pronotum and $1 / 3$ broader than maximum width of pronotum (Fig. 4), pubescence directed obliquely laterad; abdomen subparallel; metatarsus with two basal articles of about the same length and the third one slightly shorter. Male. Tergite 8 transverse and truncate apically (Fig. 52). Sternite 8 slightly transverse and rounded posteriorly (Fig. 53). Median lobe of aedeagus with broadly triangular apical part of tubus in lateral view (Fig. 48), bulbus enlarged and bearing two small angular anterior projections in dorsal view (Fig. 49), internal sac with structures as illustrated (Figs 48-50). Female. Tergite 8 similar to that of male (Fig. 55). Sternite 8 broadly rounded posteriorly (Fig. 56). Spermatheca with capsule wider than long and funnel-shaped (Fig. 54); stem sinuate and slightly swollen basally (Fig. 54). 

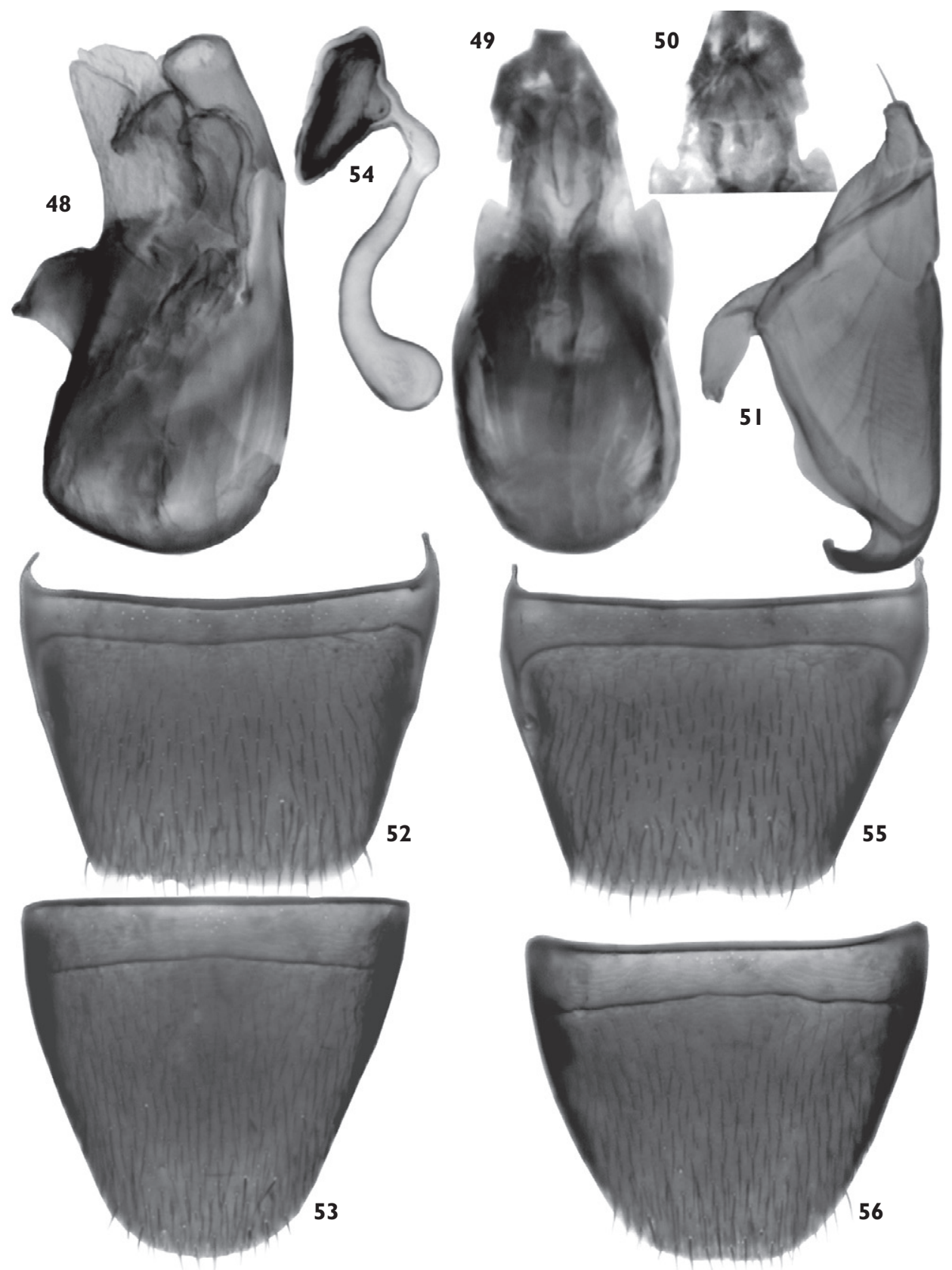

Figs 48-56. Genital structures of Gnypeta brincki: 48, median lobe of the aedeagus in lateral view, 49, dorsal view, 50, apical part of median lobe in ventral view; 51 , paramere; 52 , male tergite $8 ; 53$, male sternite $8 ; 54$, spermatheca; 55 , female tergite $8 ; 56$, female sternite 8 . 
Distribution (Fig. 191)

Gnypeta brincki is a Holarctic species with probably circumpolar distribution. In the Palaearctic region it was recorded from Norway, Sweden and Finland (Palm 1966; Smetana 2004). Here, it is recorded for the first time in North America from Quebec, Yukon Territory, Northwest Territories and Alaska.

\section{Collection and habitat data}

Adults were collected in June, July, and August. The Quebec specimen was found in an estuary of a river, 1-2 $\mathrm{m}$ above high tide line in organic mat on sand and gravel. The Yukon and Northwest Territories specimens were captured at altitudes ranging from 1005-1280 m.

\section{Gnypeta atrolucens Casey}

(Figs 5, 23 a, b, 57-65, 192)

Casey 1894: 346, 1906: 197; Moore and Legner 1975: 421. LECTOTYPE (male): UNITED STATES: New York [in original description], Gnypeta atrolucens Casey [Casey's handwriting]; Type USNM 38867; Casey bequest 1925; Gnypeta atrolucens Lectotypus Lohse des. 1989 [designation not published]; present lectotype designation label by Klimaszewski 2008 (USNM). Examined.

\section{Material examined}

Specimens are listed in Appendix A.

\section{Diagnosis}

This species can be recognized by the following combination of characters: body length 3.2-3.4 mm (Fig. 5); elytra (at suture) about $1 / 5$ longer and $1 / 3$ wider than maximum width of pronotum (Fig. 5); abdomen at base distinctly narrower than elytra (Fig. 5); antennal articles 4-7 strongly elongate (Fig. 23 a, b); median lobe of aedeagus with triangular and constricted subapically in lateral view (Fig. 57); spermatheca with capsule longer than wide and funnel-shaped (Fig. 63), stem approximately straight or slightly curved and slightly swollen basally (Fig. 63).

\section{Description}

Body length 3.2-3.4 mm; dark brown to black, central part of elytra and tarsi or entire legs reddish brown (Fig. 5); integument strongly glossy; pubescence yellowish grey and moderately long and dense; antennal article 4 slightly shorter than preceding article, 5-7 elongate, 8-9 subquadrate or slightly elongate (Figs 23 a, b); head, pronotum and abdomen of about the same width, elytra large and distinctly broader than remainder of body (Fig. 5); head rounded posteriorly; pronotum broadest in apical third, pubescence directed anterad along midline and laterad elsewhere; elytra (at suture) about $1 / 5$ longer and 1/3 broader than maximum width of pronotum (Fig. 5), pubescence directed obliquely postero-laterad; abdomen subparal- 


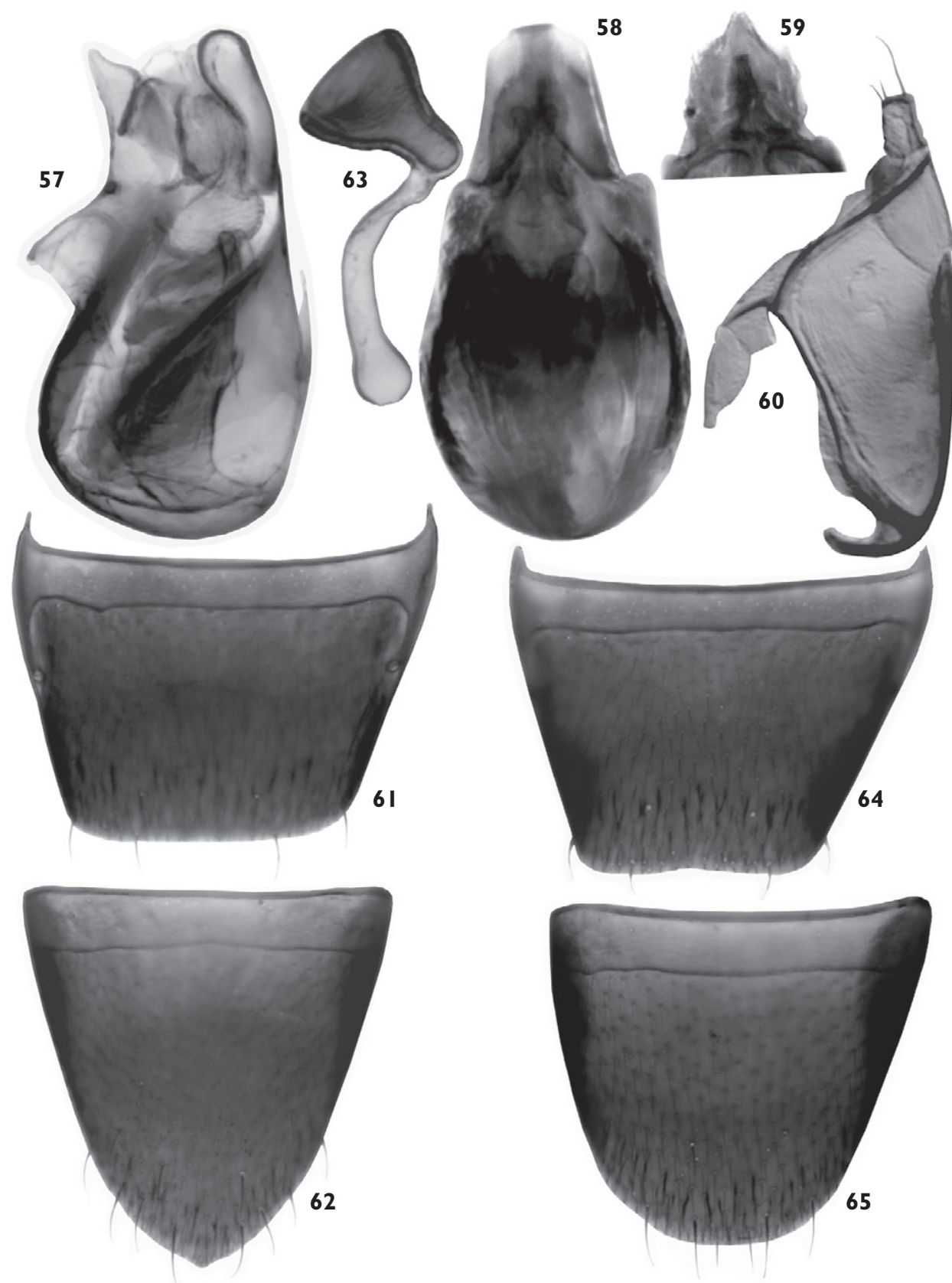

Figs 57-65. Genital structures of Gnypeta atrolucens: 57, median lobe of the aedeagus in lateral view, 58 , dorsal view, 59 , apical part of median lobe in ventral view; 60 , paramere; 61 , male tergite $8 ; 62$, male sternite $8 ; 63$, spermatheca; 64 , female tergite 8 ; 65, female sternite 8 . 
lel; metatarsus with two basal articles of about the same length and the third one slightly shorter. Male. Tergite 8 transverse and truncate apically (Fig. 61). Sternite 8 elongate and pointing medially (Fig. 62). Median lobe of aedeagus with triangular and produced apical part of tubus in lateral view (Fig. 57); bulbus enlarged and bearing two angular anterior projections in dorsal view (Fig. 58); internal sac with structures as illustrated (Figs 58, 59). Female. Tergite 8 similar to that of male (Fig. 64). Sternite 8 broadly rounded apically (Fig. 65). Spermatheca with capsule longer than wide and funnel-shaped (Fig. 63), stem slightly curved and slightly swollen basally (Fig. 63).

Distribution (Fig. 192)

Gnypeta atrolucens was described from New York (Casey 1894), and it was later reported from the Catskill Mts., New York (Casey 1906: 197). We report this species for the first time from Canada in Quebec and southeastern Labrador.

\section{Collection and habitat data}

Adults were captured from July through August at altitudes from $61 \mathrm{~m}$ to $853 \mathrm{~m}$.

\section{Comments}

In the original description, Casey (1894) did not specify the number of specimens on which the description was based and therefore we have designated the only male in Casey's type collection as the lectotype.

\section{Gnypeta sellmani Brundin}

(Figs 6, 24 a, b, 66-74, 193)

Gnypeta sellmani Brundin 1929: 14; Palm 1966: 139; Smetana 2004: 490. TYPE LOCALITY: SWEDEN, "Bei dem Bahnhof Torneträsk, 13.VIII.1927, Regio subarctica". Holotype not examined.

\section{Material examined}

Specimens are listed in Appendix A.

\section{Diagnosis}

This species can be recognized by the following combination of characters: body length 3.0-3.4 mm (Fig. 6); elytra (at suture) about as long as pronotum and about $1 / 4$ wider than maximum width pronotum (Fig. 6); abdomen at base about as wide as elytra (Fig. 6); antennal articles 4-6 moderately elongate, 7-9 about as long as wide or slightly transverse (Figs $24 \mathrm{a}, \mathrm{b}$ ); median lobe of aedeagus with apex narrowly triangular and strongly produced (Fig. 66); spermatheca with capsule about as wide as long and funnel-shaped (Fig. 72); stem sinuate and slightly swollen basally (Fig. 72). 

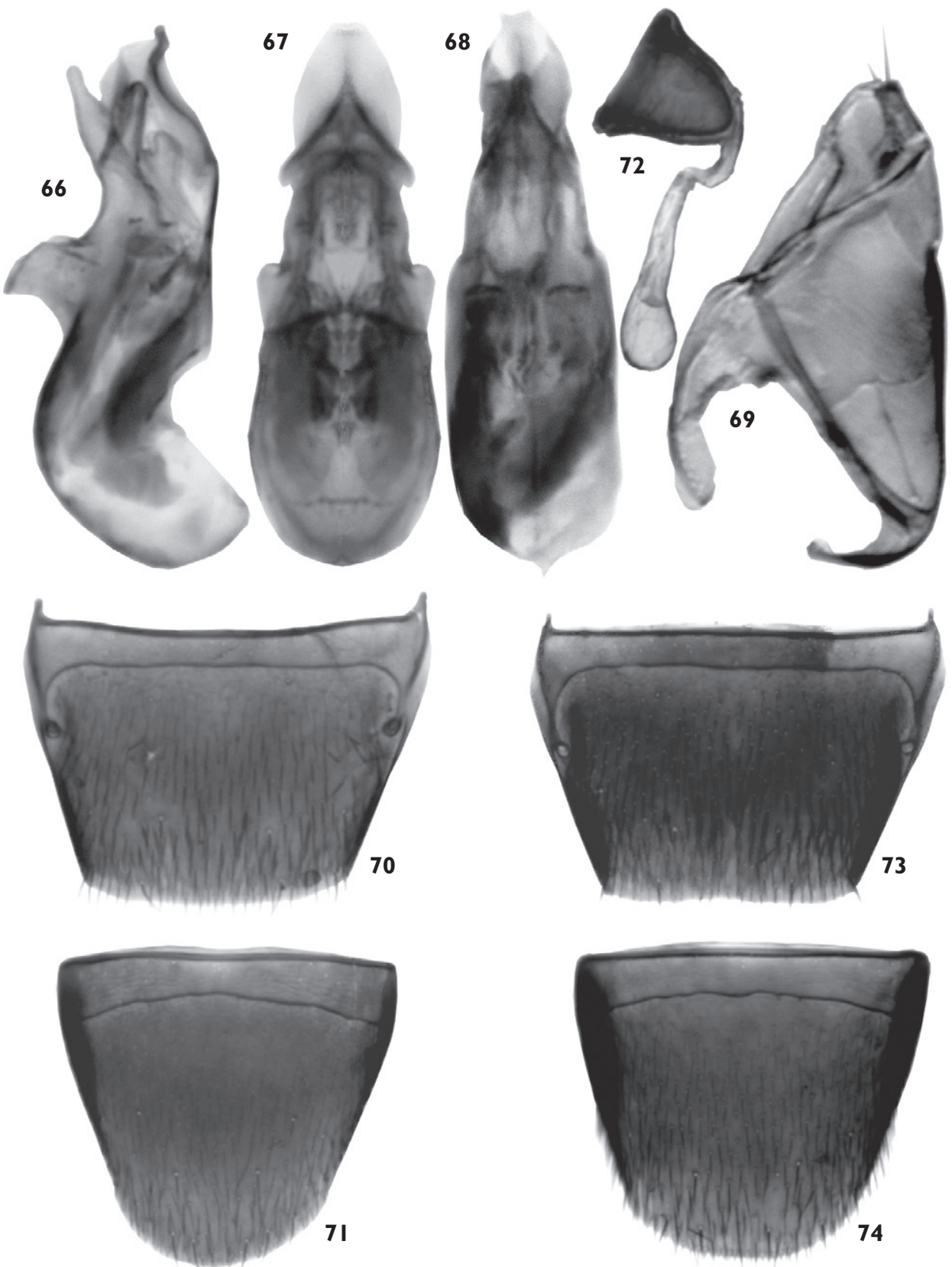

Figs 66-74. Genital structures of Gnypeta sellmani: 66, median lobe of the aedeagus in lateral view, 67, dorsal view, 68, apical part of median lobe in ventral view; 69, paramere; 70, male tergite $8 ; 71$, male sternite $8 ; 72$, spermatheca; 73 , female tergite $8 ; 74$, female sternite 8 . 


\section{Description}

Body length 3.0-3.4 mm; dark brown to black, sometimes central part of elytra and tarsi reddish brown (Fig. 6); integument moderately glossy; pubescence yellowish grey and moderately long and dense; antennal article 4 slightly shorter than preceding article, 4-6 elongate, and 7-9 about as long as wide to slightly transverse (Figs $24 \mathrm{a}, \mathrm{b}$ ); head and pronotum of about the same width; elytra and abdomen wider than either head or pronotum; elytra small and short (Fig. 6); head rounded posteriorly; pronotum broadest in apical third, pubescence directed anterad along midline and laterad elsewhere; elytra (at suture) about as long as pronotum and $1 / 4$ broader than maximum width of pronotum (Fig. 6), pubescence directed obliquely postero-laterad; abdomen subparallel, about as wide as elytra at base (Fig. 6); metatarsus with two basal articles of about the same length and the third one slightly shorter. Male. Tergite 8 transverse and truncate apically (Fig. 70). Sternite 8 elongate and rounded posteriorly (Fig. 71). Median lobe of aedeagus with narrowly produced apical part of tubus in lateral view (Fig. 66); bulbus enlarged and bearing two angular anterior projections in dorsal view (Fig. 67); internal sac with structures as illustrated (Figs 67, 68). Female. Tergite 8 similar to that of male (Fig. 73). Sternite 8 broadly rounded apically (Fig. 74). Spermatheca with capsule about as wide as long and funnel-shaped (Fig. 72), stem sinuate and slightly swollen basally (Fig. 72).

Distribution (Fig. 193)

Gnypeta sellmani is a Holarctic species with a likely circumpolar distribution. In the Palaearctic region it is recorded from Norway, Sweden, Finland and the north European territory of Russia (Smetana 2004). Here, it is recorded for the first time in North America from Quebec, Manitoba, Saskatchewan, Yukon Territory, Northwest Territories and Alaska. In Quebec several specimens were captured from Mont Albert (1233 $\mathrm{m})$ and Mont Jacques Cartier $(1333 \mathrm{~m})$ where other insect species with a northern distribution pattern are known to occur.

\section{Collection and habitat data}

Adults were collected in June, July and August from moss, near body of water, or by treading sedges around edge of temporary pond. Collecting sites ranged in altitude from $66 \mathrm{~m}$ to $1333 \mathrm{~m}$.

\section{Comments}

The late Steve Ashe (University of Kansas) worked on the revision of Nearctic Gnypeta but was not able to complete it. Some specimens of this species that he studied were returned to $\mathrm{CNC}$ with his 1987 identification labels as two new species, G. tintinnabula Ashe and $G$. dialepta Ashe [manuscript - unpublished names]. His specimens were misidentified and belong to G. sellmani Brundin. 


\section{Gnypeta dentata Klimaszewski, sp. nov.}

urn:lsid:zoobank.org:act:F1457DAA-A6BF-4814-A8BF-BEE50404EB1F

(Figs 7, 25 a, b, 75-82, 194)

HOLOTYPE (male): CANADA, Northwest Territories, Unnamed Lake, $18 \mathrm{mi}$ NW Inuvik, via East Channel, [ $\approx 68^{\circ} 21^{\prime} \mathrm{N}, 133^{\circ} 43^{\prime}$ W] 26.VI.1972, A. Smetana, CNC No. 23677 (CNC). PARATYPES: listed in Appendix A.

\section{Etymology}

This species is named for distinct dents on male tergite 8 .

\section{Diagnosis}

This species can be recognized by the following combination of characters: body length 2.5-2.7 mm (Fig. 7); elytra (at suture) about as long as pronotum and 1/4 wider than maximum width of pronotum (Fig. 7); abdomen at base slightly narrower than elytra (Fig. 7); antennal articles 4-6 subquadrate to moderately elongate, articles 7-9 slightly transverse (Figs $25 \mathrm{a}, \mathrm{b}$ ); median lobe of aedeagus with apex narrowly produced with sinuate margins in lateral view (Fig. 75); spermatheca with capsule funnel-shaped and cylindrical (Fig. 80); stem curved and slightly swollen basally (Fig. 80); male tergite 8 with four apical dents (Fig. 78).

\section{Description}

Body length 2.5-2.7 mm; dark brown to black, sometimes central part of elytra and legs or tarsi only reddish brown (Fig. 7); integument moderately strongly glossy; pubescence yellowish grey and moderately long and dense; antennal article 4 slightly shorter than preceding article, articles 4-6 quadrate to moderately elongate, and 7-9 slightly transverse (Figs $25 \mathrm{a}, \mathrm{b}$ ); head and pronotum of about the same width (Fig. 7); elytra and abdomen wider than either head or pronotum; elytra small and short (Fig. 7); head rounded basally; pronotum broadest in apical third, pubescence directed anterad along midline and laterad elsewhere; elytra (at suture) about as long as pronotum and $1 / 4$ broader than maximum width of pronotum (Fig. 7), pubescence directed obliquely postero-laterad, wavy pattern occurs on each side of disc; abdomen subparallel, slightly narrower than elytra at base (Fig. 7); metatarsus with two basal articles of about the same length and the third one slightly shorter. Male. Tergite 8 transverse and truncate apically, with four apical dents (Fig. 78). Sternite 8 transverse and slightly produced posteriorly (Fig. 79). Median lobe of aedeagus with narrowly produced apical part of tubus in lateral view (Fig. 75); bulbus enlarged without pronounced two anterior projections in dorsal view (Fig. 76); internal sac with structures as illustrated (Figs 75, 76). Female. Tergite 8 truncate apically (Fig. 81). Sternite 8 broadly rounded posteriorly and bearing median emargination (Fig. 82). Spermatheca with capsule funnel-shaped and cylindrical (Fig. 80); stem curved and swollen basally (Fig. 80). 

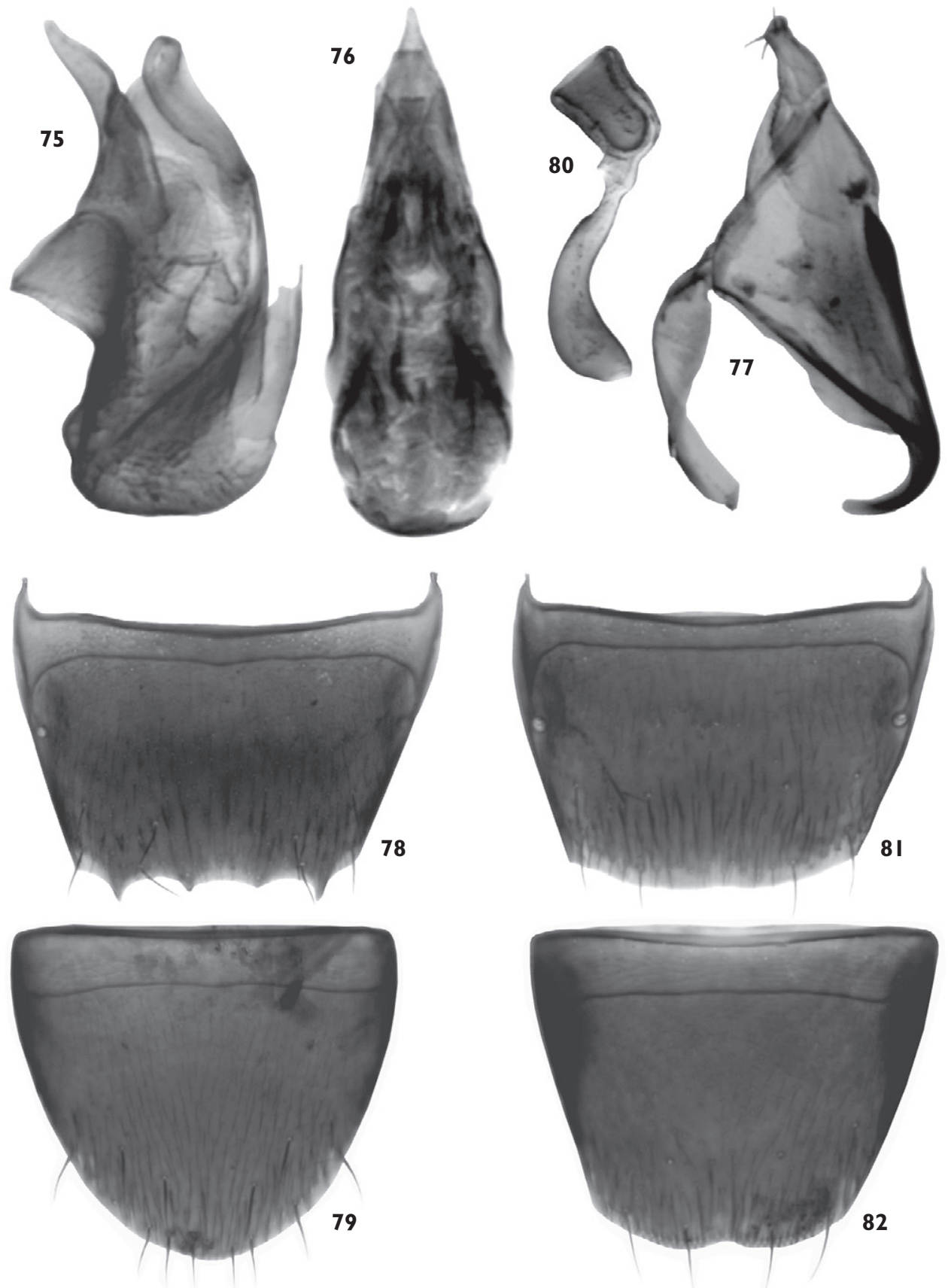

Figs 75-82. Genital structures of Gnypeta dentata: 75, median lobe of the aedeagus in lateral view, 76, dorsal view; 77 , paramere; 78 , male tergite $8 ; 79$, male sternite $8 ; 80$, spermatheca; 81 , female tergite 8 ; 82 , female sternite 8 . 
Distribution (Fig. 194)

Gnypeta dentata is a Nearctic species recorded here from Saskatchewan, Alberta, and Northwest Territories.

\section{Collection and habitat data}

Adults were collected in June, July and August; no habitat data available.

\section{Comments}

The late Gustav Adolf Lohse (Hamburg, Germany) worked on a revision of Nearctic Gnypeta, but was not able to complete his project. Some CNC specimens of this species bear his identification labels as $G$. dentata Lohse [manuscript - unpublished name].

\section{Gnypeta groenlandica Lohse}

(Figs 8, 26 a, b, 83-90, 195)

Gnypeta groenlandica Lohse 1989: 58. HOLOTYPE (male): GREENLAND, Nedre Midsommer Sö, 2.VII.1966, Can. Peary Land Expd. [Expedition] (CNC). Examined.

\section{Material examined}

Specimens are listed in Appendix A.

\section{Diagnosis}

This species can be recognized by the following combination of characters: body robust, length 3.2-3.7 mm (Fig. 8); elytra (at suture) about as long as pronotum and 1/5 wider than maximum width of pronotum (Fig. 8); abdomen at base as broad as elytra and slightly broadening posteriorly (Fig. 8); antennal article 4 subquadrate or slightly elongate, 3-6 slightly to strongly transverse, 7-9 strongly transverse (Figs 26 a, b); median lobe of aedeagus with apical part narrowly produced and sinuate laterally (Fig. 83), bulbus in dorsal view with broad lateral swells (Fig. 84); spermatheca with capsule longer than wide, funnel-shaped, lateral sides subparallel (Fig. 88); stem curved, sinuate apically and slightly swollen basally (Fig. 88); male tergite 8 strongly transverse and truncate apically (Fig. 86).

\section{Description}

Body length 3.2-3.7 mm; uniformly dark brown to black (Fig. 8); integument moderately glossy; pubescence yellowish grey and moderately long and dense; antennal article 4 subquadrate or slightly elongate, 5-6 slightly and 7-9 strongly transverse (Figs 26 a, b); head and pronotum of about the same width (Fig. 8); elytra and abdomen wider than either head or pronotum; elytra small and short (Fig. 8); head rounded basally; pronotum broadest in apical third, pubescence directed anterad along midline and laterad elsewhere; elytra (at suture) about as long as pronotum and 1/5 broader than maximum width of pronotum (Fig. 8), pubescence directed obliquely postero-laterad, 


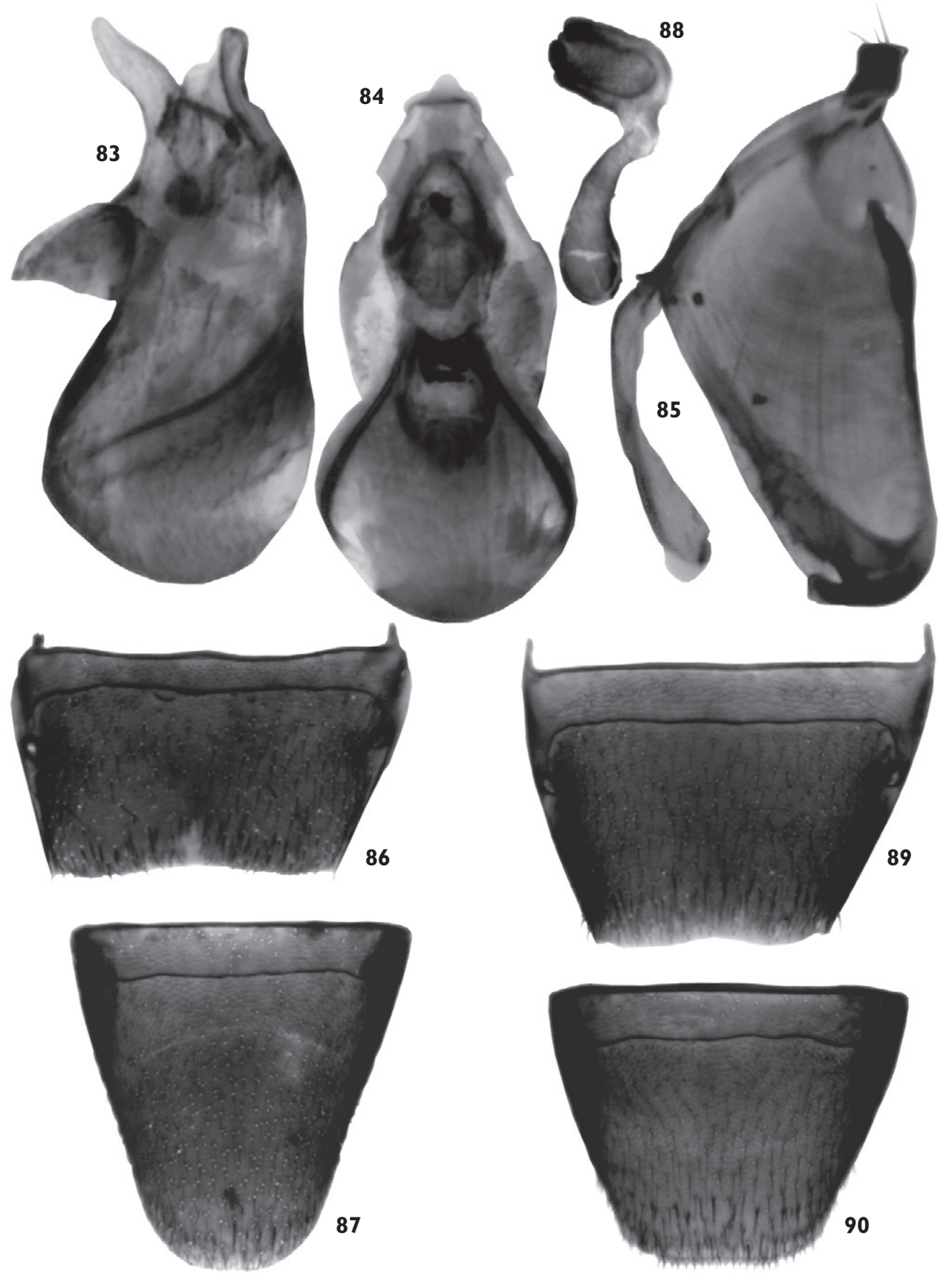

Figs 83-90. Genital structures of Gnypeta groenlandica: 83, median lobe of the aedeagus in lateral view, 84 , dorsal view; 85 , paramere; 86 , male tergite $8 ; 87$, male sternite $8 ; 88$, spermatheca; 89 , female tergite 8; 90 , female sternite 8 . 
in wavy pattern medially on each side; abdomen swollen medially, as broad as elytra at base (Fig. 8); metatarsus with two basal articles of about the same length and the third one slightly shorter. Male. Tergite 8 transverse and truncate apically and slightly concave medially (Fig. 86). Sternite 8 elongate and slightly produced posteriorly (Fig. 87). Median lobe of aedeagus with narrowly produced and sinuate apical part of tubus in lateral view (Fig. 83), sides swollen in dorsal view; bulbus moderately large (Fig. 84); internal sac with structures as illustrated (Figs 83, 84). Female. Tergite 8 truncate apically (Fig. 89). Sternite 8 broadly rounded posteriorly (Fig. 90). Spermatheca with capsule elongate, funnel-shaped with sides subparallel (Fig. 88); stem curved, sinuate apically and swollen basally (Fig. 88).

Distribution (Fig. 195)

Gnypeta groenlandica is a Nearctic species recorded here from Greenland, and newly in Canada (Manitoba, Nunavut, Yukon Territory), and the United States (Alaska).

\section{Collection and habitat data}

Adults were collected in June, July and August, mainly in alpine habitats from Salix litter, litter on shore of a lagoon, and in crown of Ross's Avens (Geum rossii), rose family (Rosaceae).

\section{Comments}

The late Steve Ashe (University of Kansas) worked on a revision of Nearctic Gnypeta, but was not able to complete it. Some CNC specimens of this species bear his identification labels as G. praeminosa Ashe, 1987 [manuscript - unpublished name].

\section{Gnypeta brevicornis Casey}

(Figs 9, 27 a, b, 91-98, 196)

Gnypeta brevicornis Casey 1906: 196; Moore and Legner 1975: 421. LECTOTYPE (male): CANADA: Br. C. [British Columbia; in original description: Kamloops and Glenora; H.F. Wickham]; brevicornis Csy. [Casey]; Type USNM 38865; Casey bequest 1925; present lectotype designation label (USNM). Present designation. Examined. PARALECTOTYPES: listed in Appendix A.

\section{Diagnosis}

This species can be recognized by the following combination of characters: body slender, length 2.7-2.9 mm, rust brown with darker head and tip of abdomen; elytra (at suture) slightly longer than pronotum and $1 / 5$ wider than maximum width of pronotum (Fig. 9); abdomen at base narrower than elytra and broadening posteriad (Fig. 9); antennal article 4 slightly elongate, 5-6 slightly transverse, articles 7-9 strongly transverse (Figs 27 a, b); median lobe of aedeagus with apical part narrowly triangular laterally (Fig. 91), bulbus in dorsal 

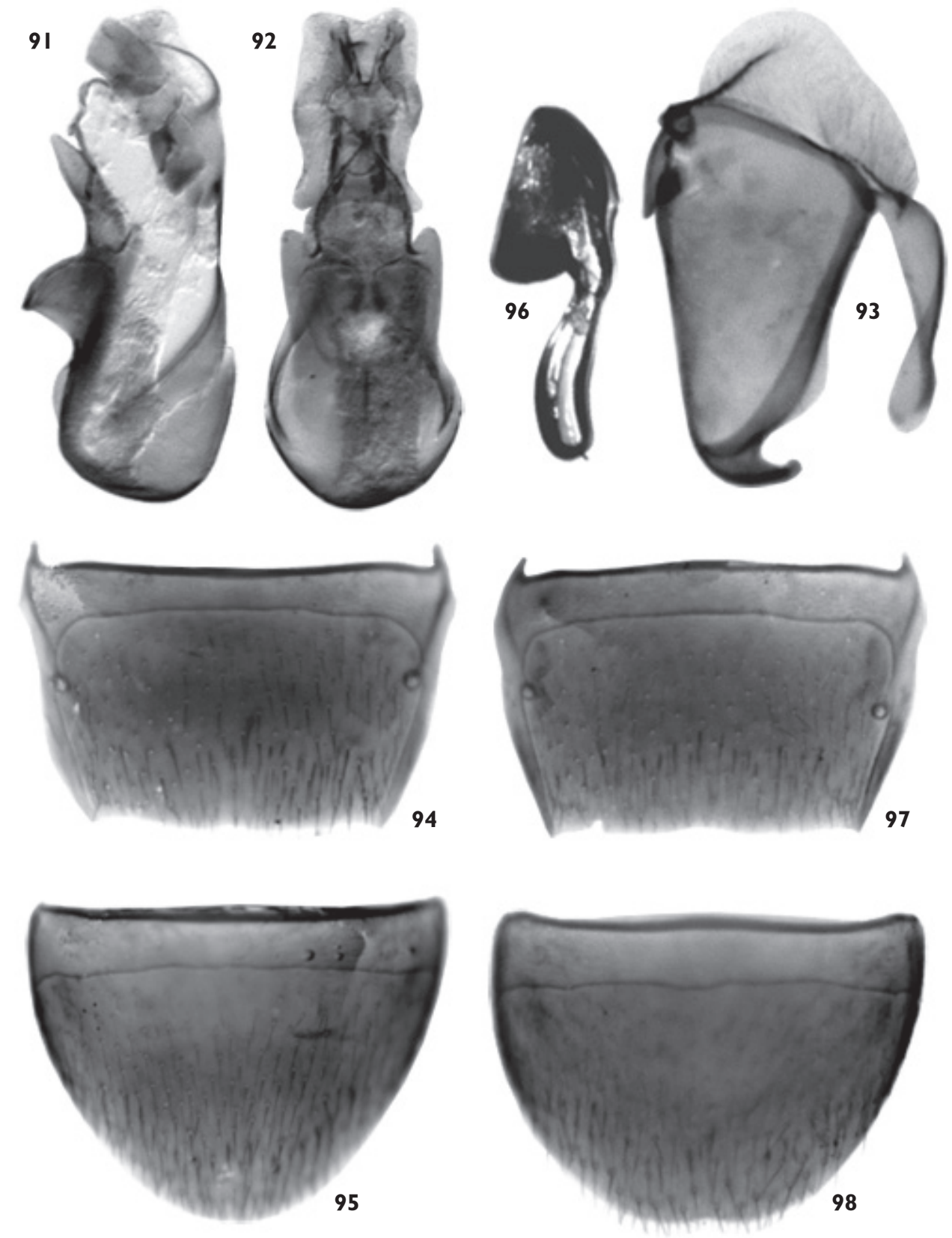

Figs 91-98. Genital structures of Gnypeta brevicornis: 91, median lobe of the aedeagus in lateral view, 92, ventral view; 93, paramere; 94, male tergite 8 ; 95, male sternite 8 ; 96, spermatheca; 97 , female tergite 8 ; 98 , female sternite 8 . 
view with two lateral projections (Fig. 92); spermatheca with capsule wider than long, funnel-shaped, lateral sides arcuate (Fig. 96); stem slightly sinuate and slightly swollen basally (Fig. 96). Gnypeta brevicornis is readily distinguishable from all other Canadian and Alaskan species (except for G. uteana, see key) by having strongly elongate basal article of metatarsus, which is as long as the two following articles combined.

\section{Description}

Body length 2.7-2.9 mm; rust brown with darker head and tip of abdomen (Fig. 9); integument moderately glossy; pubescence yellowish grey and sparse; antennal article 4 elongate, 5-6 slightly and 7-9 strongly transverse (Figs $27 \mathrm{a}$, b); head and pronotum of about the same width (Fig. 9); elytra and abdomen slightly wider than either head or pronotum; elytra small and moderately elongate (Fig. 9); head rounded posteriorly; pronotum broadest in apical third, pubescence directed postero-laterad from midline of disc; elytra (at suture) slightly longer than pronotum and $1 / 5$ broader than maximum width of pronotum (Fig. 9), pubescence directed obliquely postero-laterad from midline of disc; abdomen swollen posteriorly, as broad as elytra at base (Fig. 9); metatarsus with basal article of about the same length as the two following articles combined. Male. Tergite 8 transverse and truncate apically, slightly concave medially (Fig. 94). Sternite 8 elongate and rounded posteriorly (Fig. 95). Median lobe of aedeagus with narrowly triangular apical part of tubus in lateral view (Fig. 91); bulbus moderately large with lateral projections (Fig. 92); internal sac with structures as illustrated (Figs 91, 92). Female. Tergite 8 truncate apically (Fig. 97). Sternite 8 broadly rounded posteriorly (Fig. 98). Spermatheca with capsule transverse, funnel-shaped with sides arcuate (Fig. 96); stem slightly sinuate and swollen basally (Fig. 96).

Distribution (Fig. 196)

Gnypeta brevicornis is a western Nearctic species recorded from Glenora and Kamloops in British Columbia (Casey 1906).

\section{Collection and habitat data}

No data available.

\section{Comments}

Gnypeta brevicornis differs from all other Canadian and Alaskan Gnypeta species except for $G$. uteana by extremely elongate basal article of the metatarsus, its slender body, distinct pubescence pattern of the pronotum with setae directed posteriorly along the midline of the disc, and extremely coarse punctation in the first three visible tergal impressions. These characters are close to Tachyusa species but the genital characters of $G$. brevicornis are consistent with other Gnypeta species and the funnel-shaped capsule of the spermatheca is especially typical for the sellmani species group of Gnypeta. Additional studies are needed at the generic level to clarify the limits of the two close genera. 


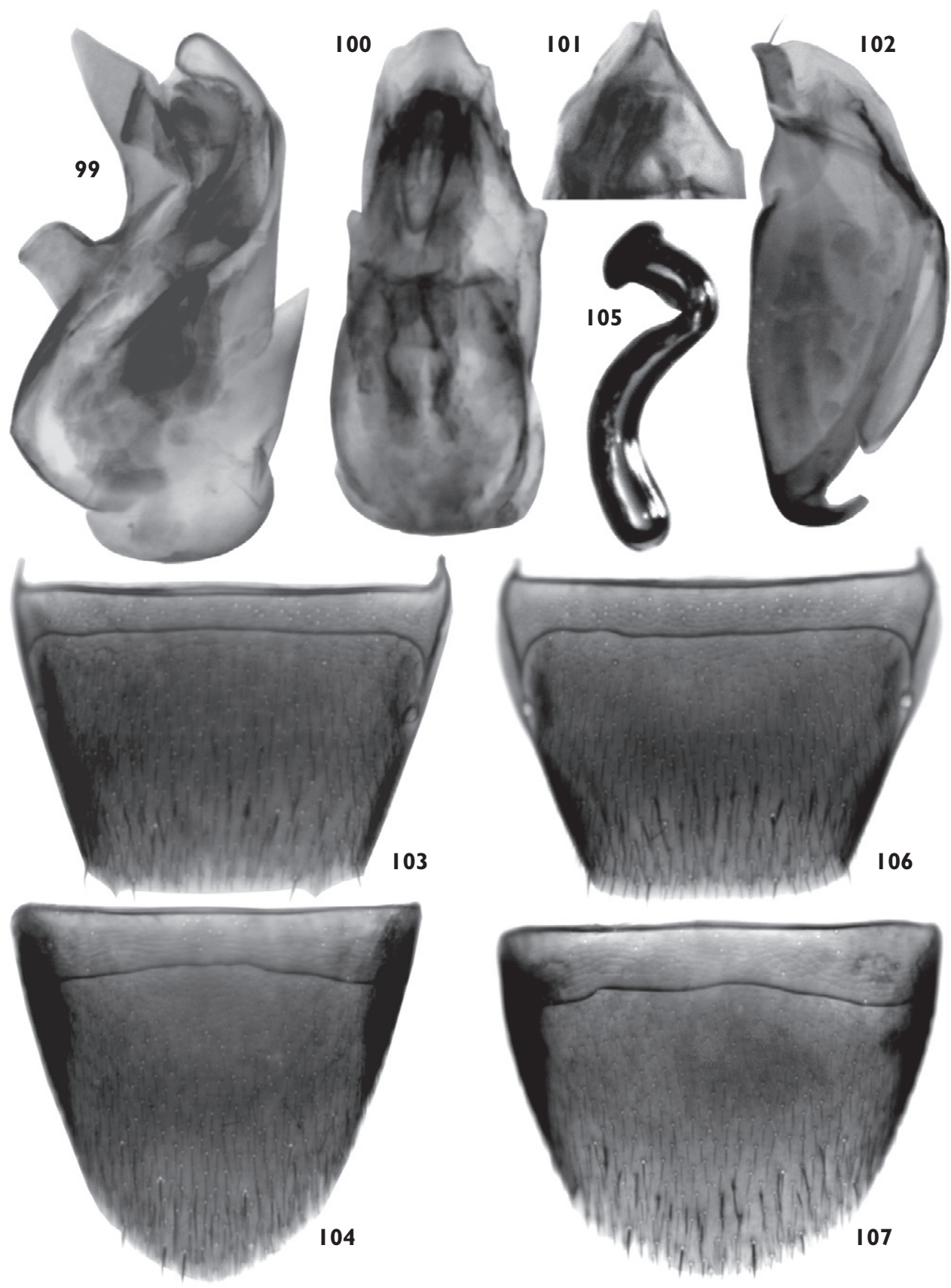

Figs 99-I 07. Genital structures of Gnypeta brincki: 99, median lobe of the aedeagus in lateral view, 100, dorsal view, 101, apical part of median lobe in ventral view; 102, paramere; 103, male tergite $8 ; 104$, male sternite $8 ; 105$, spermatheca; 106 , female tergite $8 ; 107$, female sternite 8 . 


\section{Gnypeta caerulea species group}

The caerulea species group may be characterized by the following combination of characters: spermatheca S-shaped, apical part of capsule mushroom-shaped, and stem narrow and sinuate, slightly swollen basally (Figs 105, 114); median lobe of aedeagus with short tubus broadly triangular apically in lateral view (Figs 99, 108); male tergite 8 with two small lateral dents at apical margin (Figs 103, 112).

Species included: G. caerulea (C.R. Sahlberg) and Gnypeta lohsei Klimaszewski sp. nov.

\section{Gnypeta caerulea (Sahlberg)}

(Figs 10, 28 a, b, 99-107, 197)

Aleochara caerulea C.R. Sahlberg 1830: 351. As Gnypeta: Bernhauer and Scheerpeltz 1926: 587; Palm 1966: 138; Muona 1984: 228; Campbell and Davies 1991: 100; Smetana 2004: 489. TYPE LOCALITY: FINLAND, Helsinki [in orig. description: "Ad Helsingforsiam semel tantum capta"]. Holotype not examined.

\section{Material examined}

Specimens are listed in Appendix A.

\section{Diagnosis}

This species can be recognized by the following combination of characters: body length 3.0-3.5 mm (Fig. 10); elytra (at suture) about as long as pronotum and at least $1 / 4$ wider than maximum width of pronotum (Fig. 10); abdomen at base narrower than elytra and subparallel (Fig. 10); antennal articles 4-10 strongly to moderately elongate and increasingly less so toward the apex of antennae (Figs 28 a, b); median lobe of aedeagus with apical part broadly triangular in lateral view (Fig. 99); spermatheca with capsule mushroom-shaped (Fig. 105); stem sinuate and slightly swollen basally (Fig. 105); male tergite 8 truncate and with two minute lateral dents at apical margin (Fig. 103). Gnypeta caerulea is readily distinguishable from $G$. lohsei by larger, slimmer and strongly glossy body and by the elongate antennal articles $6-10$, which are quadrate to slightly transverse in G. lohsei (Fig. 28).

\section{Description}

Body length 3.0-3.5 mm; uniformly dark brown to black, sometimes central part of elytra rust brown, tarsi and sometimes entire legs rust brown (Fig. 10); integument strongly glossy; pubescence yellowish grey and moderately long and dense; antennal article 4 strongly elongate, 5-10 moderately to strongly elongate, and increasingly less so toward the apex of antennae (Figs $28 \mathrm{a}, \mathrm{b}$ ); head and pronotum of about the same width (Fig. 10); elytra and abdomen wider than either head or pronotum; head rounded posteriorly; pronotum broadest in apical third, pubescence directed anterad along midline and laterad elsewhere; elytra at suture slightly longer than 
pronotum and at least $1 / 4$ wider than maximum width of pronotum, pubescence directed obliquely postero-laterad, in wavy pattern medially on each side of disc (Fig. 10); abdomen subparallel, narrower than elytra at base (Fig. 10), three basal tergites with deep basal impressions bearing large punctures; metatarsus with two basal articles of about the same length and the third one slightly shorter. Male. Tergite 8 transverse and truncate apically, with two minute apical dents (Fig. 103). Sternite 8 about as long as wide and rounded apically (Fig. 104). Median lobe of aedeagus with broadly triangular apical part of tubus and edges approximately straight in lateral view (Fig. 99); bulbus moderately large with two small anterior projections in dorsal view (Fig. 100); internal sac with structures as illustrated (Figs 99, 100). Female. Tergite 8 truncate apically (Fig. 106). Sternite 8 broadly rounded apically (Fig. 107). Spermatheca with capsule elongate, mushroom-shaped (Fig. 105); stem sinuate and slightly swollen basally (Fig. 105).

Distribution (Fig. 197)

Gnypeta caerulea is a Holarctic species with circumpolar distribution. Smetana (2004) listed this species from Europe, Asia, and North America. Muona (1984), Campbell and Davies (1991), and Gouix and Klimaszewski (2007) recorded this species from Newfoundland. Majka and Klimaszewski (2008) provided new records for Nova Scotia and Prince Edward Island. We report this species for the first time from New Brunswick, Quebec, Ontario, Manitoba, Saskatchewan, Alberta, Yukon Territory, Northwest Territories and Alaska.

\section{Collection and habitat data}

In the United Kingdom, G. caerulea was reported from river margins and in wet moss growing on boulders and rocks in rivers, waterfalls and streams (Hyman and Parsons 1994). In Canada, adults were collected in May, June, July, and September in marshy habitats, from vegetation around beaver ponds, from edges of ponds with sphagnum, and from swamp sedges.

\section{Comments}

The late Steve Ashe (University of Kansas) worked on a revision of Nearctic Gnypeta but was not able to complete it. Some CNC specimens, which belong to this species, bear his misidentification labels as "G. nebulosa Ashe" and "G. dialepta Ashe" [1987 manuscript - unpublished names].

\section{Gnypeta lohsei Klimaszewski, sp. nov.}

urn:Isid:zoobank.org:act:32E024F3-A2FB-4ACD-90D0-D4A7070241E9

(Figs 11, 29 a, b, 108-116, 198)

HOLOTYPE (male): CANADA,Alberta, Kananaskis F.E.S., [510.'34" N, 11507'46"W]

1.VIII.1971, J.M. and B.A. Campbell, CNC No. 23678 (CNC). 


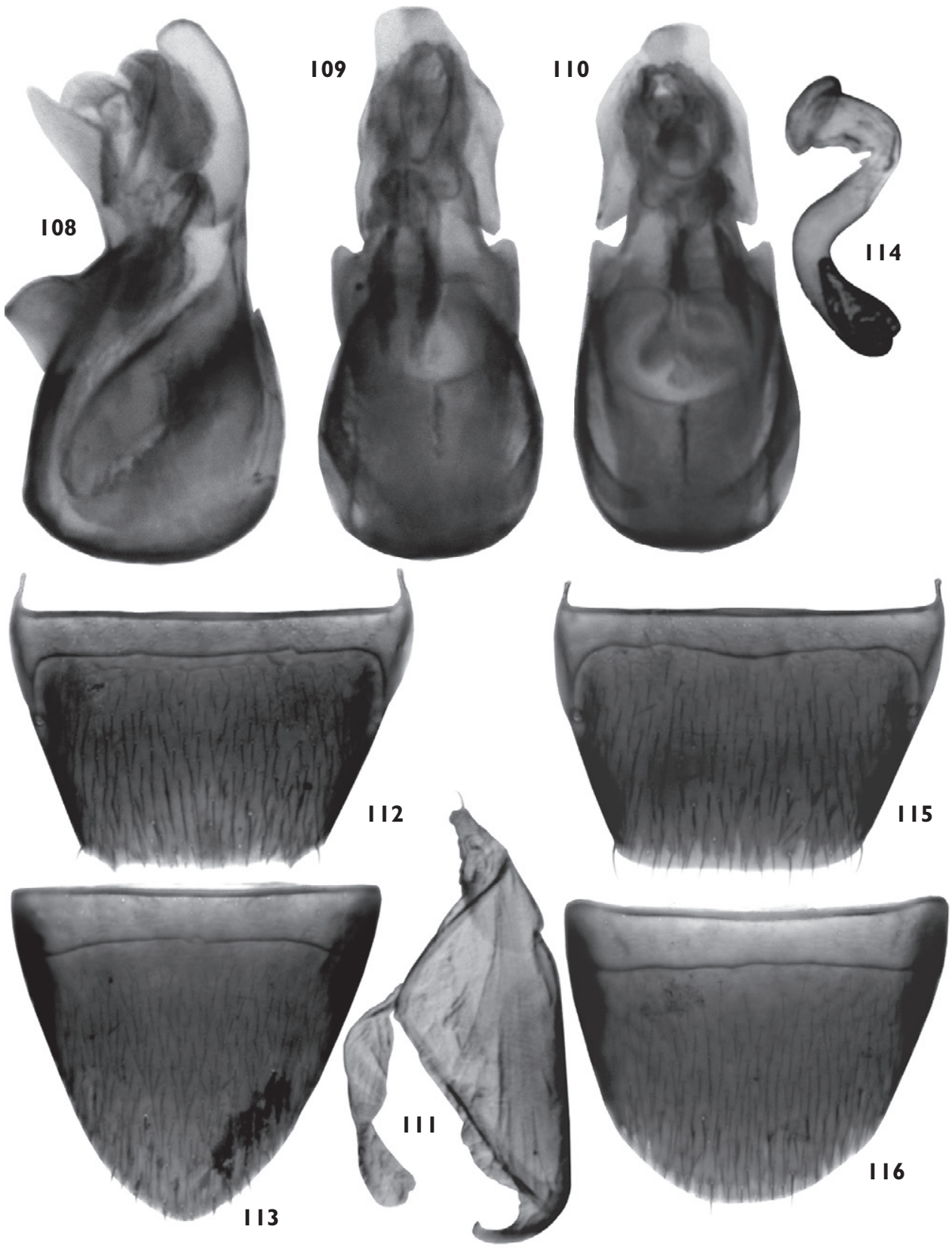

Figs I 08-I I 6. Genital structures of Gnypeta lohsei: 108, median lobe of the aedeagus in lateral view, 109, dorsal view, 110, apical part of median lobe in ventral view; 111 , paramere; 112 , male tergite $8 ; 113$, male sternite $8 ; 114$, spermatheca; 115 , female tergite $8 ; 116$, female sternite 8 . 


\section{Material examined}

Paratypes are listed in Appendix A.

\section{Etymology}

This species is named after the late Gustav Adolf Lohse (Hamburg, Germany), who discovered it in $\mathrm{CNC}$ material.

\section{Diagnosis}

This species can be recognized by the following combination of characters: body length 2.7-3.0 mm (Fig. 11); elytra at suture slightly longer than pronotum and at least $1 / 3$ wider than maximum width of pronotum (Fig. 11); abdomen at base about as wide as elytra and subparallel or slightly swollen medially (Fig. 11); antennal articles 5-7 subquadrate, 8-10 slightly transverse (Figs 29 a, b); median lobe of aedeagus with apical part broadly triangular and edges sinuate in lateral view (Fig. 108); spermatheca S-shaped, capsule mushroom-shaped (Fig. 114); stem more or less sinuate and slightly swollen basally (Fig. 114); male tergite 8 truncate apically and with two minute lateral dents at apical margin (Fig. 112). Gnypeta lohsei is readily distinguishable from $G$. caerulea by smaller, robust and less glossy body and subquadrate antennal articles 5-7 (Figs 29 a, b).

\section{Description}

Body length 2.7-3.0 mm; uniformly dark brown to black, sometimes central part of elytra and tarsi rust brown (Fig. 11); integument moderately glossy; pubescence yellowish grey and moderately long and dense; antennal article 4 moderately elongate, 5-7 subquadrate, 8-10 slightly transverse (Figs $29 \mathrm{a}, \mathrm{b}$ ); head and pronotum of about the same width (Fig. 11); elytra and abdomen wider than either head or pronotum; head rounded posteriorly; pronotum broadest in apical third, pubescence directed anterad along midline and laterad elsewhere; elytra at suture slightly longer than pronotum and about $1 / 3$ wider than maximum width of pronotum, pubescence directed obliquely postero-laterad, in wavy pattern on medial parts of disc (Fig. 11); abdomen subparallel, almost as broad as elytra at base (Fig. 11); metatarsus with two basal articles of about the same length and the third one slightly shorter. Male. Tergite 8 transverse and truncate apically with two minute apical dents (Fig. 112). Sternite 8 as broad as long and truncate apically (Fig. 113). Median lobe of aedeagus with triangularly produced apical part of tubus and edges sinuate in lateral view (Fig. 108); bulbus moderately enlarged with two anterior projections in dorsal view (Figs 109, 110); internal sac with structures as illustrated (Figs 109, 110). Female. Tergite 8 truncate apically (Fig. 115). Sternite 8 broadly rounded posteriorly (Fig. 116). Spermatheca with capsule mushroom-shaped, elongate (Fig. 114); stem sinuate and slightly swollen basally (Fig. 114).

Distribution (Fig. 198)

Gnypeta lohsei is a Nearctic species known from Alberta, British Columbia, and Alaska and Washington state, United States. 


\section{Collection and habitat data}

Adults were collected in June, July, and August, from high altitudes of up to $2340 \mathrm{~m}$. No habitat data are available.

\section{Comments}

The late Gustav Adolf Lohse (Hamburg, Germany) worked on a revision of Nearctic Gnypeta but was not able to complete it. The CNC specimens of this species he studied bear his identification labels as $G$. albertae Lohse and $G$. paracareluea Lohse [manuscript - unpublished names].

\section{Gnypeta crebrepunctata species group}

The crebrepunctata species group may be characterized by the following combination of characters: spermatheca C-shaped, capsule and stem short, broad, and tubular or club-shaped (Figs 122, 127-129, 136); median lobe of aedeagus with enlarged bulbus (Figs 117, 118, 130-132); male tergite 8 truncate (Figs 120, 134).

Species included: G. crebrepunctata (Casey), G. manitobae Casey, G. uteana Casey and G. carbonaria Mannerheim. The following species belong to this group but do not occur in Canada: Gnypeta majuscula Casey (southern United States) and G. rubrior Tottenham (Palaearctic).

\section{Gnypeta crebrepunctata (Casey)}

(Figs 12, 30 a, b, 117-124, 194)

Tachyusa crebrepunctata Casey 1886: 203. As Gnypeta: Casey 1906: 194; Moore and Legner 1975: 421. LECTOTYPE (male): UNITED STATES OF AMERICA: California, [in orig. description: Monterey Co.]; Type USNM 38861, Casey bequest 1925; Gnypeta crebrepunctata Csy. [Casey], Lectotypus Lohse des. 1988 [designation not published]; Lectotype, male, Tachyusa crebrepunctata Casey [=Gnypeta], des. Klimaszewski 2007 (USNM). Present designation. Examined.

Gnypeta oblata Casey 1911: 168. As synonym of G. helenae: Moore and Legner 1975: 422. LECTOTYPE (female): UNITED STATES OF AMERICA: California, Siskiyou Co; oblata Csy [handwritten by Casey]; Type USNM 38881; Casey bequest 1925 (USNM). Present designation. Examined. PARALECTOTYPE (sex?): UNITED STATES OF AMERICA: California, Siskiyou Co; oblata - 2 Paratype USNM 38881 (USNM). Examined. New synonymy.

\section{Material examined}

Specimens are listed in Appendix A. 


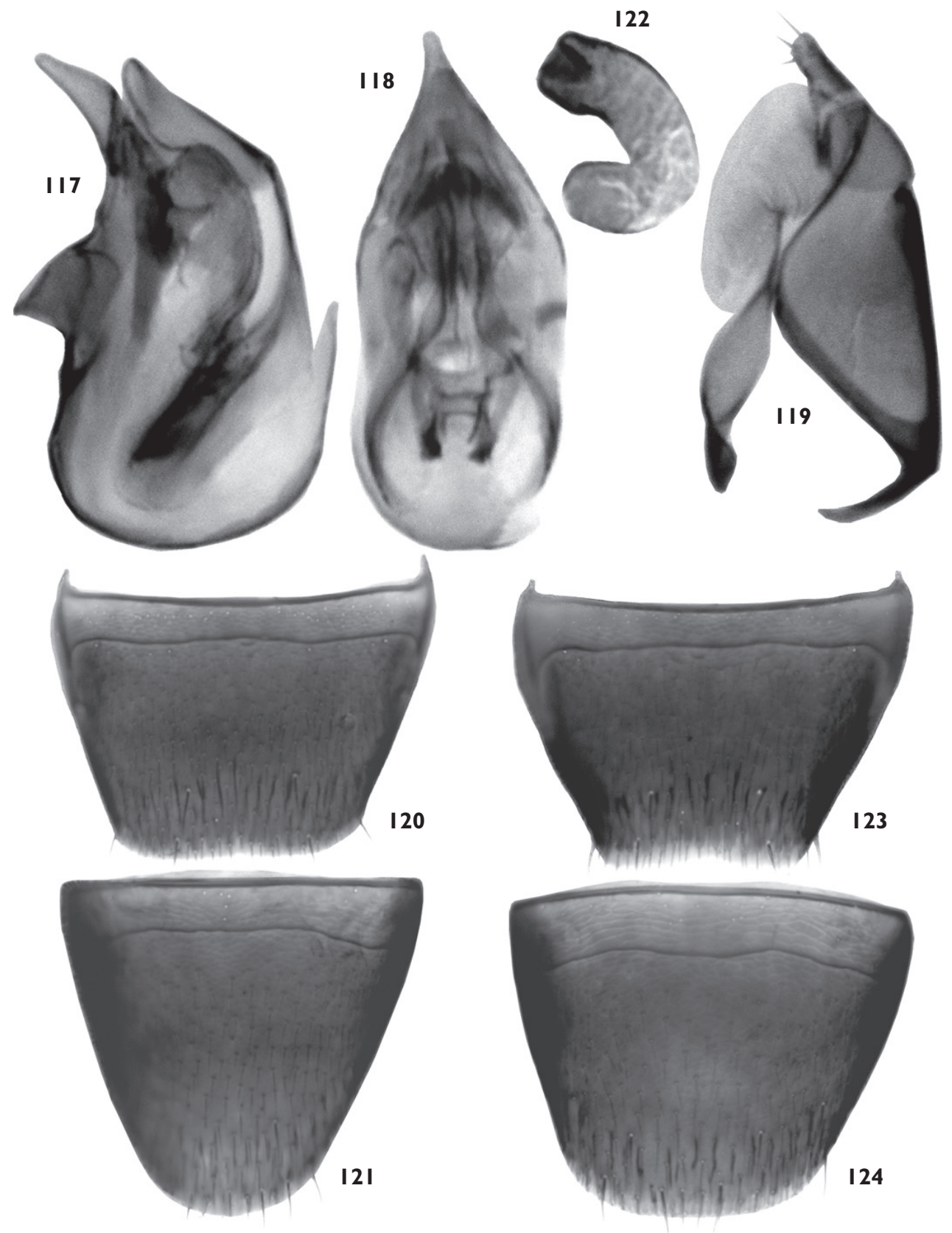

Figs I I 7-I 24. Genital structures of Gnypeta crebrepunctata: 117, median lobe of the aedeagus in lateral view, 118 , dorsal view; 119 , paramere; 120 , male tergite $8 ; 121$, male sternite $8 ; 122$, spermatheca; 123 , female tergite $8 ; 124$, female sternite 8 . 


\section{Diagnosis}

This species can be recognized by the following combination of characters: body length 3.0-3.2 mm, integument moderately glossy (Fig. 12); elytra at suture slightly longer than pronotum and at least $1 / 3$ wider than maximum width of pronotum (Fig. 12); abdomen at base slightly narrower than elytra and subparallel (Fig. 12); antennal articles 4-7 moderately elongate, 8-10 slightly transverse (Figs $30 \mathrm{a}, \mathrm{b}$ ); median lobe of aedeagus with apical part narrowly produced (Figs 117, 118); spermatheca C-shaped, with broadly tubular capsule (Fig. 122); stem broadly tubular and short (Fig. 122); male tergite 8 truncate apically (Fig. 120). The shape of the spermathecal capsule and the shape of the apical portion of the median lobe of the aedeagus are the best characters for recognition of this species.

\section{Description}

Body length 2.7-3.0 mm; uniformly dark brown to black, with tarsi rust brown (Fig. 12); integument moderately glossy; pubescence yellowish grey and moderately long and dense; antennal articles 4 -7 moderately elongate, 8-10 slightly transverse (Figs $30 \mathrm{a}, \mathrm{b}$ ); head and pronotum of about the same width (Fig. 12); elytra and abdomen wider than either head or pronotum; head rounded posteriorly; pronotum broadest in apical third, pubescence directed anterad along midline and laterad elsewhere; elytra at suture slightly longer than pronotum and about $1 / 3$ wider than maximum width of pronotum, pubescence directed obliquely postero-laterad, in wavy pattern medially on each side of disc (Fig. 12); abdomen subparallel, slightly narrower than elytra at base (Fig. 12); metatarsus with two basal articles of about the same length and the third one slightly shorter. Male. Tergite 8 transverse and truncate apically with slight median emargination (Fig. 120). Sternite 8 slightly elongate and broadly rounded apically (Fig. 121). Median lobe of aedeagus with narrowly produced apical part of tubus in lateral view (Fig. 117); internal sac with structures as illustrated (Figs 117, 118). Female. Tergite 8 truncate apically (Fig. 123). Sternite 8 broadly rounded apically (Fig. 124). Spermatheca C-shaped, capsule tubular and short (Fig. 122); stem short and broadly tubular (Fig. 122).

Distribution (Fig. 194)

Gnypeta crebrepunctata is a western Nearctic species known from Oregon and California (Casey 1886, 1906, 1911). We report this species for the first time from the province of British Columbia.

\section{Collection and habitat data}

Adults from British Columbia were collected in July and August, from gravel along the edge of a creek, and from rotting Boletus mushrooms.

\section{Comments}

The Queen Charlotte Islands specimens had the C-shaped spermatheca typical for this species, but two females had the slightly broadened apical portion of the capsule 
appearing slightly club-shaped, while the remaining specimens here examined had Cshaped spermatheca with the capsule approximately evenly tubular without broadened apical portion. We regard the slightly broadened apical portion of the capsule as a variable character and within the range variation of $G$. crebrepunctata.

The California specimens are on average slightly smaller than those from British Columbia but have a similar external morphology and shape of genital structures.

\section{Gnypeta manitobae Casey}

(Figs 13, 31 a, b, 125-129)

Gnypeta manitobae Casey 1906: 196. As synonym of G. bockiana Casey: Moore and Legner 1975: 421. Synonymy confirmed here as not valid. LECTOTYPE (female): CANADA: Manitoba, Winnipeg; Hanham; Type USNM 38864; manitobae Csy. [handwritten by Casey]; Casey bequest 1925; lectotype designation label by Lohse 1988 [designation not published] (USNM). Present designation. Examined.

\section{Material examined}

The lectotype only.
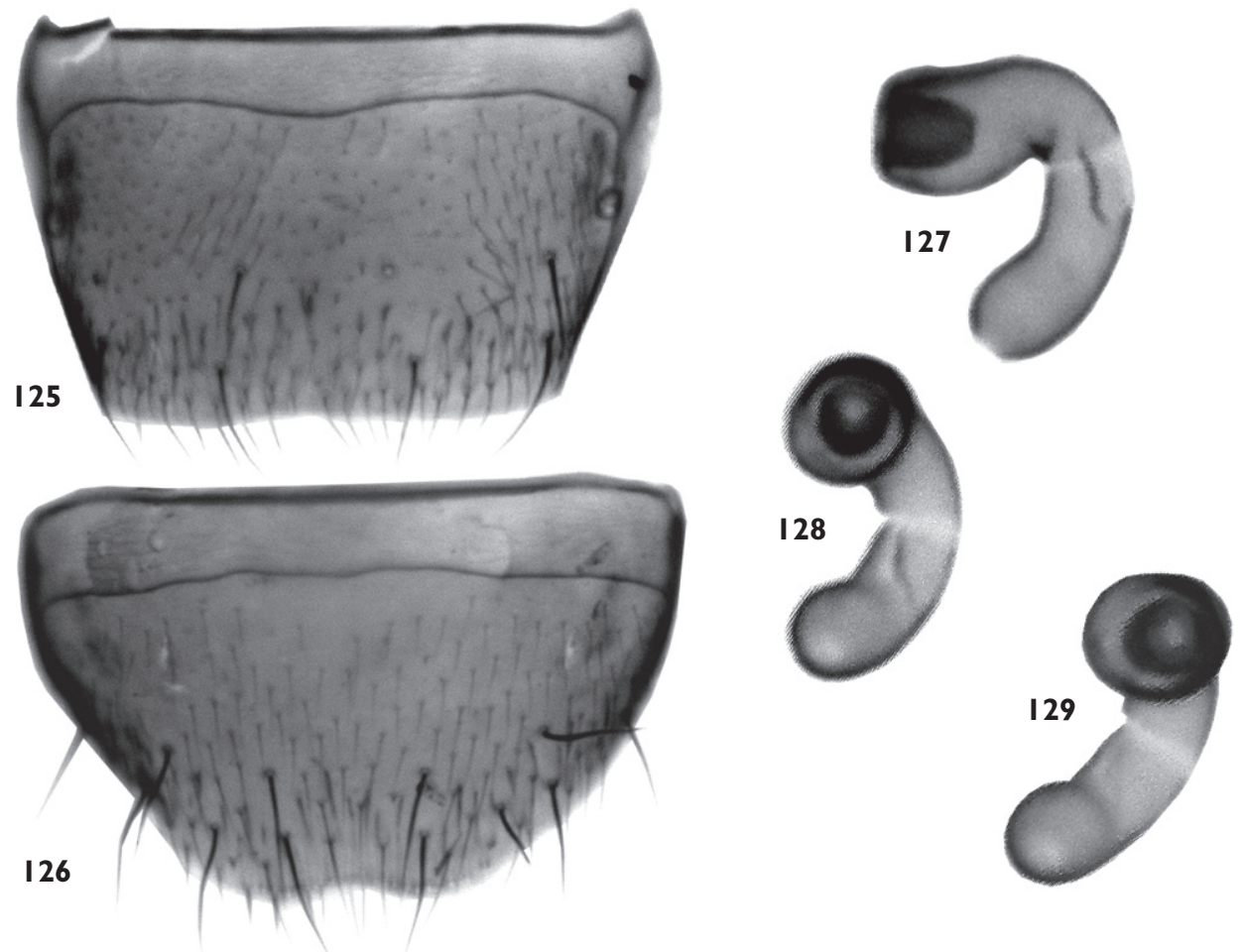

Figs I25-I29. Genital structures of Gnypeta manitobae (lectotype): 125, female tergite 8; 126, female sternite 8; 127-129, spermatheca. 
Diagnosis (based on female)

This species is known from a single female and is similar to G. crebrepunctata. The two species have a very similar shape of the spermatheca and terminal segments and can be distinguished only by the differences in external morphology and the different geographic ranges. Gnypeta manitobae, in comparison with G. crebrepunctata, has a more transverse pronotum (Fig. 13), and the base of the abdomen is as broad as the elytra (Fig. 13).

From other Nearctic Gnypeta species, it can be distinguished by the following combination of characters: body subparallel (Fig. 13), length $2.6 \mathrm{~mm}$; elytra at suture as long as pronotum and at least $1 / 4$ wider than maximum width of pronotum (Fig. 13); abdomen subparallel and at base about as broad as elytra (Fig. 13); antennal articles 4-7 strongly elongate, 8-10 quadrate to slightly transverse (Fig. 31 b). Spermatheca C-shaped with capsule tubular (Figs 127-129).

\section{Description}

Body length $2.6 \mathrm{~mm}$; uniformly dark brown with two basal antennal articles and tarsi rust brown (Fig. 13); integument moderately glossy; pubescence yellowish grey and moderately long and dense; antennal articles 4-7 strongly elongate, 8-10 quadrate to slightly transverse (Fig. 31 b); head and pronotum of about the same width (Fig. 13); elytra and abdomen wider than either head or pronotum; head rounded posteriorly; pronotum broadest in apical third, pubescence directed anterad along midline and laterad elsewhere; elytra at suture about as long as pronotum and about 1/4 wider than maximum width of pronotum, pubescence directed obliquely postero-laterad, in wavy pattern medially on each side of disc (Fig. 13); abdomen subparallel, at base about as broad as elytra (Fig. 13); metatarsus with basal article slightly longer than second, and the third one slightly shorter than second. Male. Unknown. Female. Tergite 8 truncate apically (Fig. 125). Sternite 8 broadly rounded apically with shallow median emargination (Fig. 126). Spermatheca C-shaped, capsule tubular and short (Figs 127-129); stem short and broadly tubular (Fig. 127). Spermatheca is similar to that of G. crebrepunctata.

\section{Distribution}

Gnypeta manitobae is known only from a single type specimen captured in Winnipeg, Manitoba (Casey 1906).

\section{Collection and habitat data}

No data available.

\section{Comments}

Casey (1906) in the original description of $G$. manitobae mentioned a male specimen from Winnipeg, Manitoba, but did not clearly specify how many specimens he had studied. There is only one specimen in the Casey collection from that locality under G. manitobae and it is a female, which was probably misidentified by Casey as a male. 
Casey did not designate the holotype in his original description and therefore we designated the only syntype female from Winnipeg as the lectotype.

\section{Gnypeta uteana (Casey)}

(Figs 14, 32 a, b, 131-138, 196)

Tachyusa uteana Casey 1911: 169. As Gnypeta: Moore and Legner 1975: 422. LECTOTYPE (female): UNITED STATES OF AMERICA: Utah [southwestern Utah], Weidt, uteana Csy [Casey]; Type USNM 38883, Casey Bequest 1925; Gnypeta uteana Csy. Lectotypus Lohse des.1988 [designation not published]; Lectotype, female, Tachyusa uteana Casey [=Gnypeta], des. Klimaszewski 2007 (USNM). Present designation. Examined.

Gnypeta boulderensis Casey 1911: 167. As synonym of G. helenae: Moore and Legner 1975: 422. LECTOTYPE (female): UNITED STATES OF AMERICA: Boulder Co., Boulder Co.; boulderensis Csy [Casey's handwriting]; Type USNM, 38870 (USNM). Present designation. Examined. New synonymy.

Gnypeta punctatula Casey 1906: 194. As synonym of G. helenae: Moore and Legner 1975: 422. LECTOTYPE (female): UNITED STATES OF AMERICA: California, Pomona Mts., Sept. [ember]; [in original description: H.C. Fall]; punctatula Csy [Casey's handwriting]; Type USNM 38869; Casey bequest 1925 (USNM). Present designation. Examined. New synonymy.

\section{Material examined}

Specimens are listed in Appendix A.

\section{Diagnosis}

This species can be recognized by the following combination of characters: body length 2.6-2.8 mm (Fig. 14); elytra at suture slightly longer than pronotum and about 1/3 wider than maximum width of pronotum (Fig. 14); abdomen at base distinctly narrower than elytra and subparallel (Fig. 14); antennal article 4 strongly elongate, 5 subquadrate or slightly elongate, 7-10 slightly transverse (Figs $32 \mathrm{a}$, b); median lobe of aedeagus with apical part moderately broad and produced in lateral view (Fig. 130); spermatheca C-shaped, with broadly tubular and mushroom-shaped capsule (Fig. 136); stem broadly tubular and short (Fig. 136); male tergite 8 truncate apically and with slight apical emargination (Fig. 134); female sternite 8 with strong median apical emargination (Fig. 138). The slim, strongly glossy body, basal article of metatarsus almost as long as the two following articles combined; distinct shape of spermatheca; medially emarginated female sternite 8 , and the shape of the apical portion of the median lobe of the aedeagus are the best characters for recognition of this species.

\section{Description}

Body length 2.6-2.8 mm; uniformly dark brown to black, elytra often rust brown medially, and tibiae and/or tarsi rust brown (Fig. 14); integument strongly glossy; pubescence yellowish grey and moderately long and dense; antennal article 4 strongly 


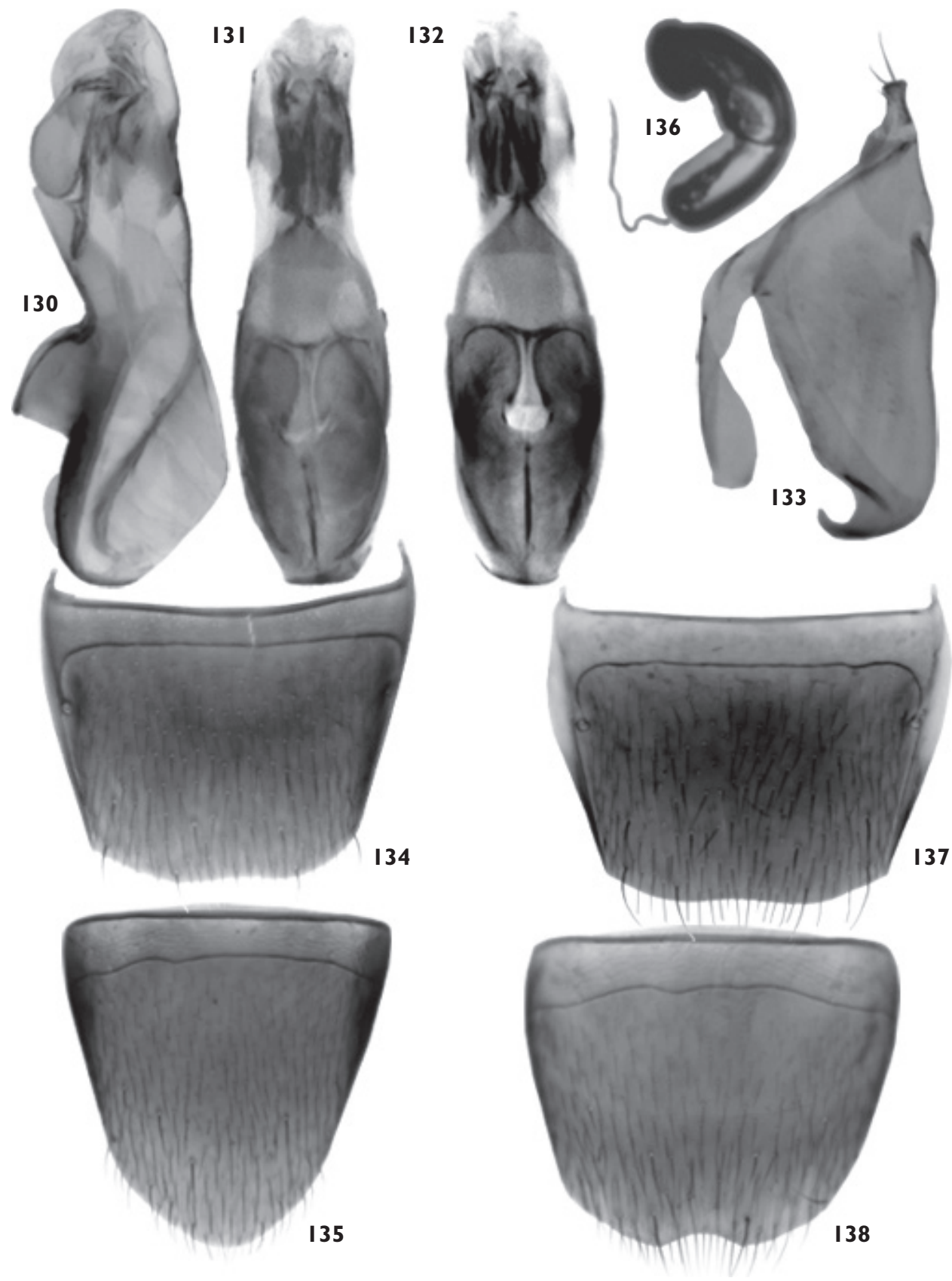

Figs I30-I38. Genital structures of Gnypeta uteana: 130, median lobe of the aedeagus in lateral view, 131 , dorsal view, 132 , ventral view; 133 , paramere; 134 , male tergite $8 ; 135$, male sternite $8 ; 136$, spermatheca; 137 , female tergite $8 ; 138$, female sternite 8 . 
elongate, 5 subquadrate or slightly elongate, 7-10 slightly transverse (Fig. 32 a, b); head and pronotum of about the same width (Fig. 14); elytra and abdomen (less so) wider than either head or pronotum; head rounded posteriorly; pronotum broadest in apical third, pubescence directed anterad along midline and laterad elsewhere; elytra at suture slightly longer than pronotum and about $1 / 3$ wider than maximum width of pronotum, pubescence directed obliquely postero-laterad, in wavy pattern medially on each side of disc (Fig. 14); abdomen subparallel, distinctly narrower than elytra at base (Fig. 14); metatarsus with basal article strongly elongate and about as long as the two following articles combined. Male. Tergite 8 transverse and truncate apically with slight median emargination (Fig. 134). Sternite 8 elongate and broadly rounded apically (Fig. 135). Median lobe of aedeagus with triangular and moderately broad apical part of tubus in lateral view (Fig. 130); bulbus moderately enlarged in dorsal view (Figs 131, 132); internal sac with structures as illustrated (Figs 130-132). Female. Tergite 8 truncate apically (Fig. 137). Sternite 8 broadly rounded posteriorly with deep median emargination (Fig. 138). Spermatheca with tubular and short, mushroom-shaped capsule (Fig. 136); stem short and broadly tubular (Fig. 136).

Distribution (Fig. 196)

Gnypeta uteana is a western Nearctic species known from southwestern Utah, Colorado and California (Casey 1906, 1911). We report this species for the first time from the province of Alberta.

\section{Collection and habitat data}

Adults from Alberta were collected in July and August, some from altitudes up to 2040 m. Habitat data not available.

\section{Gnypeta carbonaria (Mannerheim)}

(Figs 15, 33 a, b, 139-147, 199)

Bolitochara carbonaria Mannerheim 1830: 75; Palm 1966: 141; Smetana 2004: 489. TYPE LOCALITY: FINLAND: in original description: "Ad Willnäs in Finlandia australi semel capta". Holotype not examined.

\section{Material examined}

Specimens are listed in Appendix A.

\section{Diagnosis}

This species can be recognized by the following combination of characters: body length 2.7-3.0 mm (Fig. 15); elytra at suture slightly longer than pronotum and about 1/4 wider than maximum width of pronotum (Fig. 15); abdomen at base distinctly narrower than elytra and subparallel (Fig. 15); antennal article 4 strongly elongate, 5-7 moderately elongate, 8-10 subquadrate to slightly transverse (Figs 33 a, b); median lobe of aedeagus with apical part triangularly produced with sinuate edges in lateral 

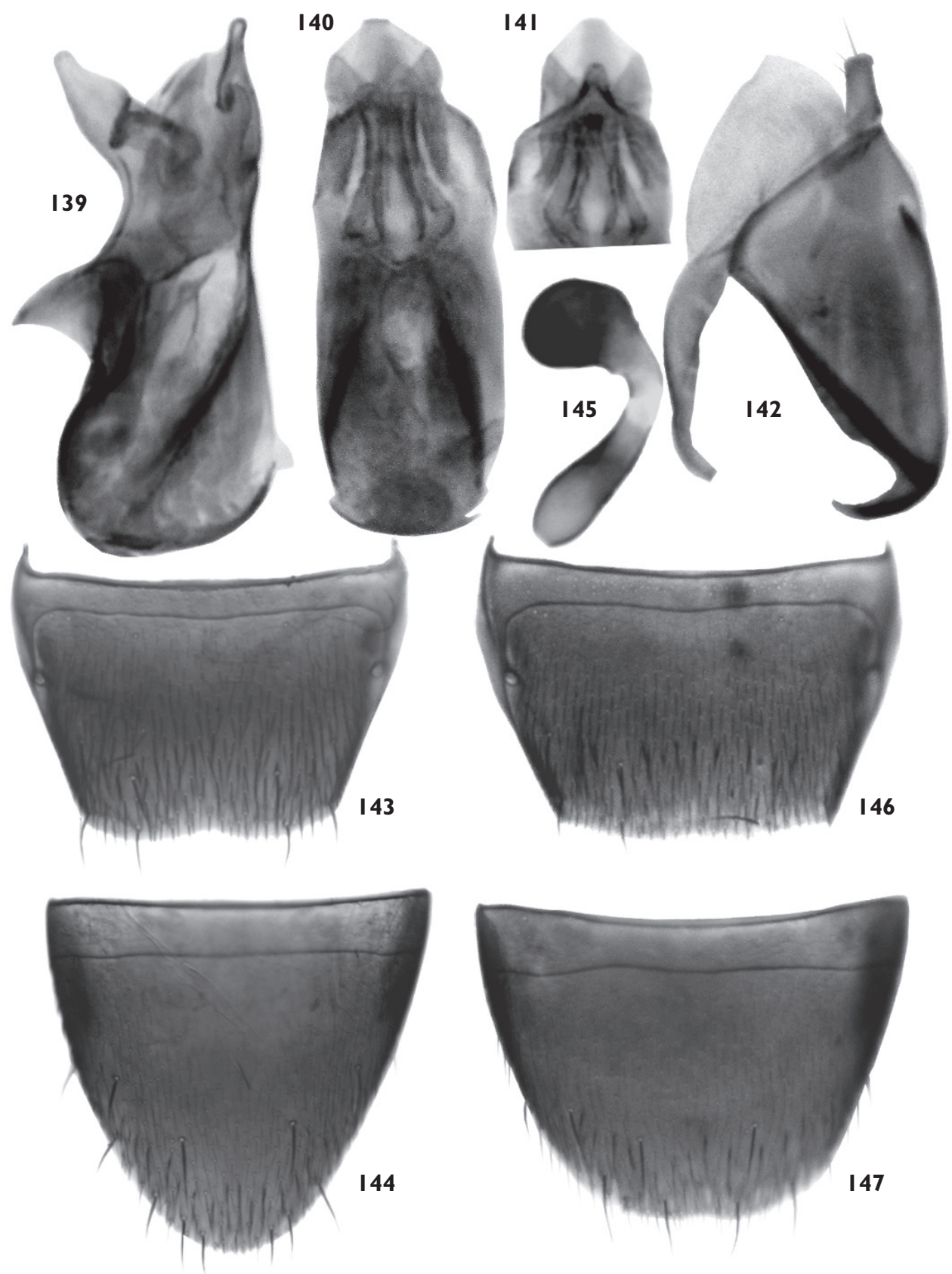

Figs I39-I47. Genital structures of Gnypeta brincki: 139, median lobe of the aedeagus in lateral view, 140 , dorsal view, 141 , apical part of median lobe in ventral view; 142 , paramere; 143 , male tergite $8 ; 144$, male sternite $8 ; 145$, spermatheca; 146 , female tergite $8 ; 147$, female sternite 8 . 
view (Fig. 139); spermatheca club-shaped, apical part of capsule approximately spherical connected to narrow and short tubular part (Fig. 145); stem narrow, tubular, short and slightly swollen posteriorly (Fig. 145); male tergite 8 truncate apically and with slight apical emargination (Fig. 143); female sternite 8 with small apical emargination (Fig. 147). The antennal proportions; distinct shape of spermatheca; medially emarginated female sternite 8 , and the shape of the apical portion of the median lobe of the aedeagus are the best characters for recognition of this species.

\section{Description}

Body length 2.7-3.0 mm; dark brown to black, elytra often rust brown medially, and legs and/or tarsi rust brown (Fig. 15); integument moderately glossy; pubescence yellowish grey and moderately long and dense; antennal article 4 strongly elongate, 5-7 moderately elongate, 8-10 subquadrate to slightly transverse (Figs $33 \mathrm{a}, \mathrm{b}$ ); head and pronotum of about the same width (Fig. 15); elytra and abdomen (less so) wider than either head or pronotum; head rounded posteriorly; pronotum broadest in apical third, pubescence directed anterad along midline and laterad elsewhere; elytra at suture slightly longer than pronotum and about 1/4 wider than maximum width of pronotum, pubescence directed obliquely postero-laterad, in wavy pattern medially on each side of disc (Fig. 15); abdomen subparallel, distinctly narrower than elytra at base (Fig. 15); metatarsus with basal article slightly longer than the following article. Male. Tergite 8 transverse and truncate apically with small median emargination (Fig. 143). Sternite 8 elongate and broadly rounded apically (Fig. 144). Median lobe of aedeagus with triangularly produced apical part of tubus in lateral view (Fig. 139); bulbus moderately large in dorsal view (Fig. 140); internal sac with complex structures as illustrated (Figs 139-141). Female. Tergite 8 truncate apically (Fig. 146). Sternite 8 broadly rounded posteriorly with small median emargination (Fig. 147). Spermatheca with tubular and short, club-shaped capsule (Fig. 145); stem short and broadly tubular (Fig. 145).

\section{Distribution (Fig. 199)}

Gnypeta carbonaria is a Holarctic species and is here reported from Canada and Alaska for the first time. It was previously known from the Palaearctic region and was recorded from Europe, Northern Africa, and Asia including eastern and western Siberia (Smetana 2004). We discovered this species to be transcontinental in North America with records from Alaska, Northwest Territories, Alberta, Saskatchewan, Manitoba, Ontario, Quebec, and New Brunswick.

\section{Collection and habitat data}

In Canada and Alaska, adults were collected in July and August from wet ground near a bog, in rotten fungus, and in a UV light trap.

\section{Comments}

We compared North American specimens of G. carbonaria with those from Sweden and found no distinct external or genital morphological differences between 
the two populations. We also compared the newly designated female lectotype of Gnypeta brunnescens Casey with Canadian and Swedish specimens of G. carbonaria and found no differences between female genital features. However, Casey's type of $G$. brunnescens differs from both populations by the light brown body colour instead of dark brown or black and by a slightly different pubescence pattern on the pronotum, which may be caused by the preparation of the specimen. Due to these differences, we hesitate to formally synonymize $G$. brunnescens with $G$. carbonaria. Additional specimens of $G$. brunnescens are needed from the type locality to confirm its taxonomic status.

\section{Gnypeta helenae species group}

The helenae species group may be characterized by the following combination of characters: spermatheca S-shaped, capsule pipe-shaped and consisting of a small cylindrical apical part angularly connected with a narrow, tubular and sinuate stem (Figs 153, 161); median lobe of aedeagus with narrowly triangular apical portion of tubus in lateral view (Figs 148, 156); male tergite 8 truncate and slightly emarginated medially (Figs 151, 159); and female sternite 8 deeply emarginated medially (Figs 155, 163).

Species included: G. helenae Casey, and G. canadensis Klimaszewski sp. nov.

\section{Gnypeta helenae Casey}

(Figs 16, 34 a, b, 148-155, 194)

Gnypeta helenae Casey 1906: 193; Moore and Legner 1975: 422. TYPE LOCALITY: UNITED STATES OF AMERICA: Montana, Kalispell, H.F. Wickham (USNM). Holotype not examined, type on loan.

Gnypeta deserticola Casey 1906: 193. Synonymized by Moore and Legner 1975: 422. LECTOTYPE (male): UNITED STATES OF AMERICA: Ari. [zona]; [in orig. description: Benson, G.W. Dunn]; deserticola Csy [Casey's handwriting]; Type USNM, 38860; Casey bequest 1925; Lectotypus, male, Gnypeta deserticola Casey, des. V.I. Gusarov 2000 [designation not published] (USNM). Present designation. Examined. Synonymy confirmed. Gnypeta oregona Casey 1906: 199. Synonymized by Moore and Legner 1975: 422. LECTOTYPE (male): UNITED STATES OF AMERICA: Oregon, Portland, [H.F. Wickham]; oregona Csy [Casey]; Type USNM 38859; Casey determ. helenae 2; Lectotypus Gnypeta oregona Casey, V.I. Gusarov des. 2002 [designation not published]; present designation label (USNM). Examined. PARALECTOTYPES: Oregon, Portland; [Casey des. male = female]; oregona 2, Paratype USNM 38851 (USNM) female; Portland, oregona 3, Paratype USNM 38859 (USNM) female. Examined. Synonymy confirmed.

\section{Material examined}

Specimens are listed in Appendix A. 

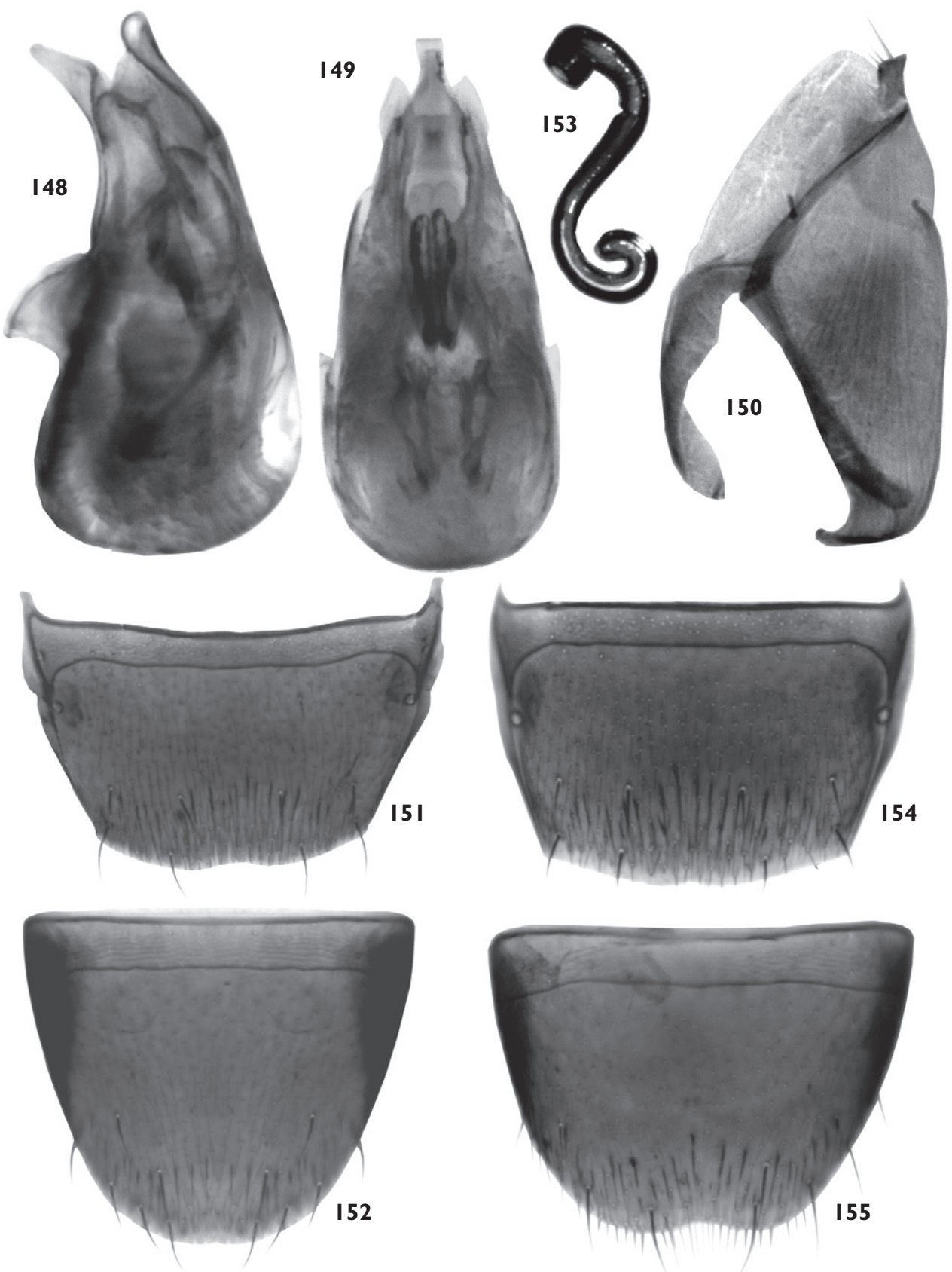

Figs I 48-I 55. Genital structures of Gnypeta helenae: 148, median lobe of the aedeagus in lateral view, 149 , dorsal view; 150 , paramere; 151 , male tergite $8 ; 152$, male sternite $8 ; 153$, spermatheca; 154 , female tergite $8 ; 155$, female sternite 8 . 


\section{Diagnosis}

This species can be recognized by the following combination of characters: body length 2.7-3.0 mm (Fig. 16); elytra at suture as long as pronotum or slightly longer and about 1/4 wider than maximum width of pronotum (Fig. 16); abdomen at base distinctly narrower than elytra and subparallel (Fig. 16); antennal article 4 strongly elongate, 5-10 moderately to strongly elongate (Figs $34 \mathrm{a}, \mathrm{b}$ ); median lobe of aedeagus with apical part narrowly triangularly produced with sinuate edges in lateral view (Fig. 148); spermatheca S-shaped, capsule pipe-shaped and consisting of a small cylindrical apical part angularly connected with a narrowly elongate sinuate stem (Fig. 153); male tergite 8 truncate apically and with slight apical emargination (Fig. 151); female sternite 8 with large apical emargination (Fig. 155). The elongate antennal articles 1-10; distinct shape of spermatheca; medially emarginated female sternite 8 , and the shape of the apical portion of the median lobe of the aedeagus are the best characters for recognition of this species. This species is very similar to $G$. canadensis sp. nov., from which it may be distinguished with certainty by the genital differences: spermatheca with thicker posterior part of capsule and stem, and broader and less ventrally produced apical part of median lobe.

\section{Description}

Body length 2.7-3.0 mm; dark brown to black, elytra and legs and/or tarsi often rust brown (Fig. 16); integument strongly glossy; pubescence yellowish grey and moderately long and dense; antennal article 4 strongly elongate, 5-10 moderately to strongly elongate (Figs $34 \mathrm{a}, \mathrm{b}$ ); head and pronotum of about the same width (Fig. 16); elytra and abdomen (less so) wider than either head or pronotum; head rounded posteriorly; pronotum broadest in apical third, pubescence directed anterad along midline and laterad elsewhere; elytra at suture as long as pronotum or slightly longer and about 1/4 wider than maximum width of pronotum, pubescence directed obliquely postero-laterad, in wavy pattern medially on each side of disc (Fig. 16); abdomen subparallel, distinctly narrower than elytra at base (Fig. 16); metatarsus with basal article slightly longer than the following article. Male. Tergite 8 transverse and truncate apically with small median emargination (Fig. 151). Sternite 8 elongate and broadly rounded apically (Fig. 152). Median lobe of aedeagus with narrowly produced apical part of tubus in lateral view (Fig. 148); bulbus moderately enlarged in dorsal view (Fig. 149); internal sac with structures as illustrated (Figs 148, 149). Female. Tergite 8 truncate apically (Fig. 154). Sternite 8 broadly rounded posteriorly with large median emargination (Fig. 155). Spermatheca S-shaped, capsule pipe-shaped and consisting of a small cylindrical apical part angularly connected to a narrow tubular and sinuate stem (Fig. 153).

\section{Distribution (Fig. 194)}

Gnypeta helenae is a western Nearctic species recorded from Montana (Casey 1906), and also recorded under two synonymic names from Arizona and Oregon (Casey 1906; Moore and Legner 1975). We report this species for the first time from Canada in Alberta and British Columbia. 


\section{Collection and habitat data}

Adults were collected in June, July, August and October, some from silt around Typha on a river bank.

\section{Comments}

The late Gustav Adolf Lohse (Hamburg, Germany) worked on revision of Nearctic Gnypeta but was not able to complete his project. One CNC specimen of this species bears his identification label as "G. glabra Lohse" [manuscript name].

\section{Gnypeta canadensis Klimaszewski, sp. nov.} urn:Isid:zoobank.org:act:D98C0465-D5D9-4059-A85E-8EB2DE6A2D33 (Figs 17, 35 a, b, 156-163, 198)

HOLOTYPE (male): CANADA, Ontario, Rondeau Provincial Park, South Point,

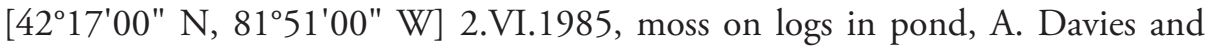
J.M. Campbell, CNC No. 23679 (CNC). PARATYPES: listed in Appendix A.

\section{Diagnosis}

Gnypeta canadensis is externally similar to $G$. helenae, from which it may be distinguished with certainty by the shape of the narrower and ventrally produced apical portion of the median lobe of the aedeagus (Fig. 156), thicker stem of the spermatheca (Fig. 161), and different geographic distribution. It may be distinguished from the other Nearctic Gnypeta species by the following combination of characters: body length 2.7-3.0 mm, integument strongly glossy (Fig. 17); elytra at suture as long as pronotum or slightly longer and about $1 / 4$ wider than maximum width of pronotum (Fig. 17); abdomen subparallel and at base distinctly narrower than elytra (Fig. 17); antennal article 4 strongly elongate, 5-10 moderately to strongly elongate (Figs 35 a, b); median lobe of aedeagus with apical part strongly produced ventrally in lateral view (Fig. 156); spermatheca S-shaped, capsule pipe-shaped and consisting of a small cylindrical apical part angularly connected to a tubular part and the elongate sinuate stem (Fig. 161); male tergite 8 truncate apically and with slight apical emargination (Fig. 159); female sternite 8 with large apical emargination (Fig. 163). The elongate antennal articles 1-10 (1-7 strongly, 8-10 slightly) (Figs $35 \mathrm{a}, \mathrm{b}$ ); distinct shape of spermatheca; medially emarginated female sternite 8 , and the shape of the apical portion of the median lobe of the aedeagus are the best characters for recognition of this species.

\section{Description}

As for $G$. helenae except for the characters of the median lobe of the aedeagus and the spermatheca (see above).

Distribution (Fig. 198)

Gnypeta canadensis is known to occur in Ontario and Alberta. 


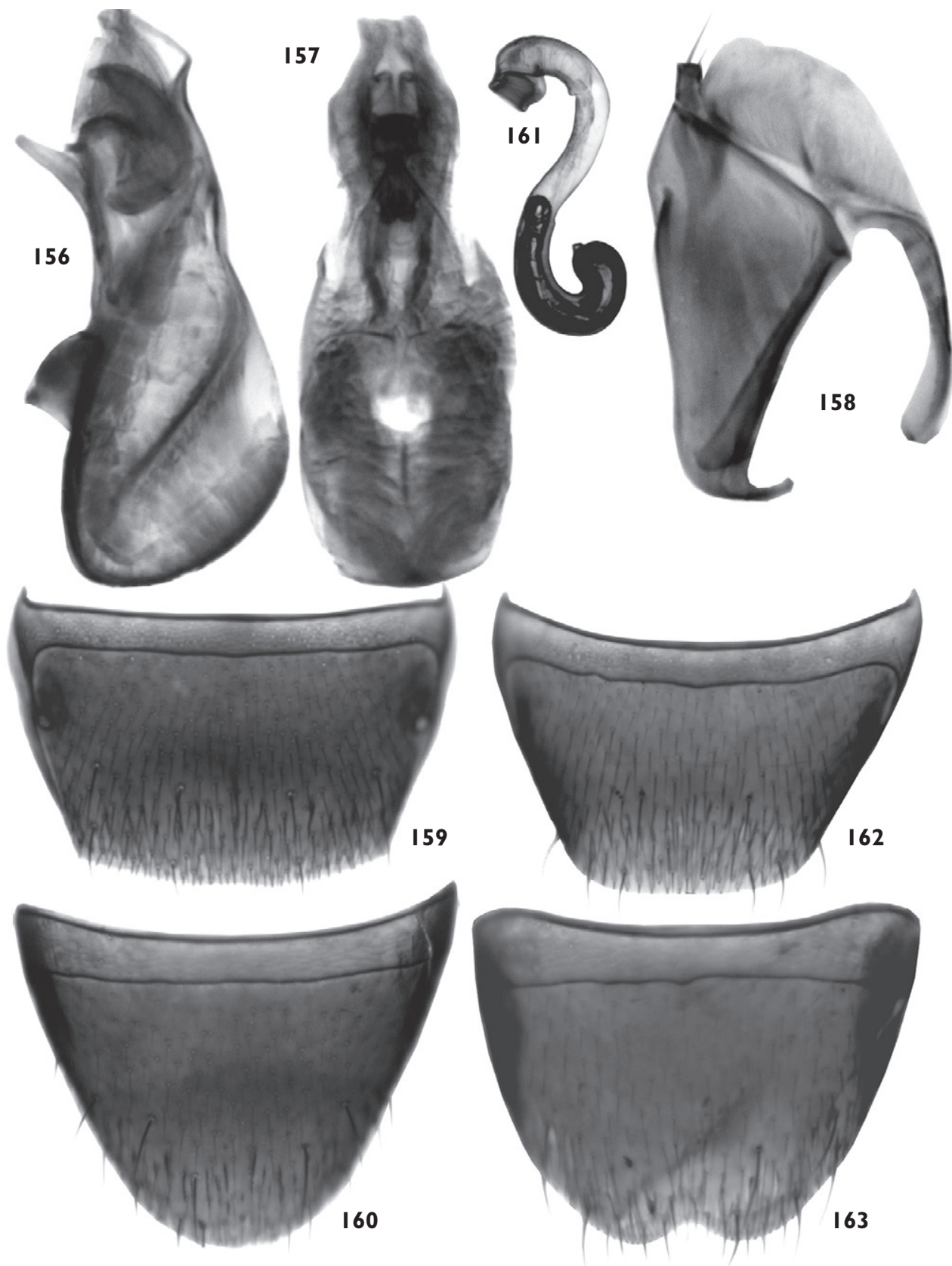

Figs I 56-I 63. Genital structures of Gnypeta canadensis: 156, median lobe of the aedeagus in lateral view, 157 , ventral view; 158 , paramere; 159 , male tergite $8 ; 160$, male sternite $8 ; 161$, spermatheca; 162 , female tergite $8 ; 163$, female sternite 8 . 


\section{Collection and habitat data}

Adults were captured in March, May and June. Some specimens were collected from an intercept trap in open marsh forest, and the holotype was captured in moss on a log.

\section{Comments}

The late Gustav Adolf Lohse (Hamburg, Germany) worked on revision of Nearctic Gnypeta but was not able to complete his project. Three CNC specimens of this species bear his identification labels as G. glabricula Lohse [manuscript name].

$G$. canadensis is similar to $G$. helenae and the two cannot be distinguished externally. They may be separated by the width of the spermatheca, the width of the apical portion of the median lobe of the aedeagus in lateral view, and by the different distribution ranges. For details, see the diagnosis and description.

Due to a lack of study material, we did not see a broad geographic variation in genital characters in this species. Should the variations in genital characters prove to be clinal based on a broader sample size in future studies and the geographic ranges overlapping between this species and $G$. helenae, the status of $G$. canadensis should be reconsidered.

\section{Gnypeta nigrella species group}

The nigrella species group may be characterized by the following combination of characters: spermatheca club-shaped, capsule approximately spherical and constricted to a narrow duct connected to a narrow, tubular and sinuate stem (Figs 169, 178, 187, 188); median lobe of aedeagus with moderately large bulbus which is streamlined with tubus in dorsal view (Figs 165, 173, 182), the internal sac with two pronounced subapical sclerites (Figs 164, 165, 177, 178, 181, 182); female sternite 8 emarginated medially (Figs 171, 180, 189).

Species included: G. minuta Klimaszewski and Webster, G. nigrella LeConte, G. saccharina Klimaszewski and Webster.

\section{Gnypeta nigrella (LeConte)}

(Figs 1, 2, 18, 36 a, b, 164-171, 192)

Tachyusa nigrella LeConte 1863: 29; Bland 1865: 412; Moore and Legner 1975: 422. LECTOTYPE (male): UNITED STATES OF AMERICA: "in original description: "middle and Western States"; original labels: male; nigrella Lec.; Type 6247; Aug.-Dec., MCZ Image Data Base (MCZ). Present lectotype designation by J. Klimaszewski, 2008. Examined.

\section{Material examined}

Specimens are listed in Appendix A. 

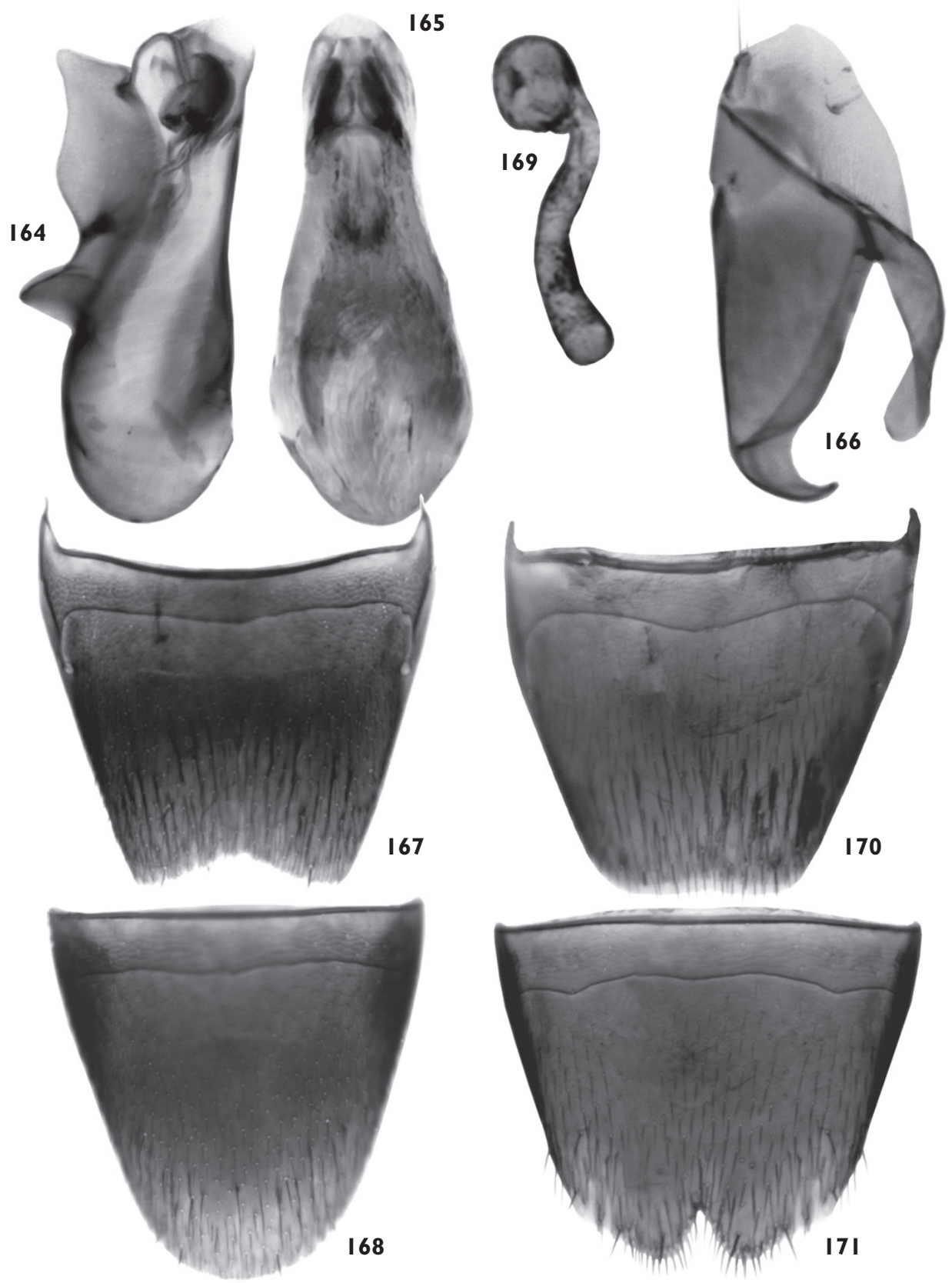

Figs I64-I7I. Genital structures of Gnypeta nigrella: 164, median lobe of the aedeagus in lateral view, 165 , dorsal view; 166 , paramere; 167 , male tergite $8 ; 168$, male sternite $8 ; 169$, spermatheca; 170 , female tergite $8 ; 171$, female sternite 8 . 


\section{Diagnosis}

This species can be recognized by the following combination of characters: body length 2.7-3.0 mm (Figs 1, 2, 18); elytra at suture as long as pronotum or slightly longer and about 1/4 wider than maximum width of pronotum (Figs 1, 2, 18); abdomen at base distinctly narrower than elytra and subparallel (Figs 1, 2, 18); antennal article 4 strongly elongate, 5-10 moderately to strongly elongate (Figs 36 a, b); median lobe of aedeagus with apical part triangularly produced with sinuate edges in lateral view (Fig. 164); spermatheca club-shaped, capsule spherical and connected to a narrowly elongate sinuate stem (Fig. 169); male tergite 8 truncate apically and with slight apical emargination (Fig. 167); female sternite 8 with large apical emargination (Fig. 171). Gnypeta nigrella has extremely similar spermatheca, and tergite and sternite 8 are similar to those of $G$. minuta and G. saccharina. Gnypeta nigrella is distinct by its very short and silky body pubescence and by only a few coarse punctures at the margins of basal tergites (Fig. 1).

\section{Description}

Body length 2.7-3.0 mm; dark brown to almost black, central and/or posterior portion of elytra often rust brown (Figs 1,2,18); integument moderately glossy; pubescence yellowish grey and moderately long and dense; antennal articles 4-7 strongly elongate, 8-10 moderately elongate (Figs $36 \mathrm{a}, \mathrm{b}$ ); head and pronotum of about the same width (Figs 1, 2, 18); elytra and abdomen (less so) wider than either head or pronotum; head rounded posteriorly; pronotum broadest in apical third, pubescence directed posterad along midline and laterad elsewhere; elytra at suture longer than pronotum and about $1 / 4$ wider than maximum width of pronotum, pubescence directed obliquely posterolaterad, in weak wavy pattern medially on each side of disc (Figs 1, 2, 18); abdomen broadening posteriorly, distinctly narrower than elytra at base (Figs 1,2, 18); metatarsus with basal article slightly longer than the following article (Fig. 1). Male. Tergite 8 emarginate apically (Fig. 167). Sternite 8 elongate and broadly rounded apically (Fig. 168). Median lobe of aedeagus with swollen ventral part of tubus and with produced apex in lateral view (Fig. 164); bulbus moderately large in dorsal view (Fig. 165); internal sac with complex structures as illustrated (Figs 164, 165). Female. Tergite 8 truncate apically (Fig. 170). Sternite 8 broadly rounded posteriorly with deep V-shaped apical emargination (Fig. 171). Spermatheca club-shaped, capsule spherical apically and constricted basally, connected to a narrow tubular and sinuate stem (Fig. 169).

Distribution (Fig. 192)

Gnypeta nigrella is an eastern Nearctic species previously recorded from Massachusetts, Pennsylvania, and Maryland (LeConte 1863; Bland 1865; Moore and Legner 1975). We report this species for the first time from Canada (New Brunswick) and from Vermont in the United States.

\section{Collection and habitat data}

Adults captured in New Brunswick occurred on bare, sun exposed, fine sand/gravel near margin of a medium-sized stream, others were found on bare mud and among cobblestones 


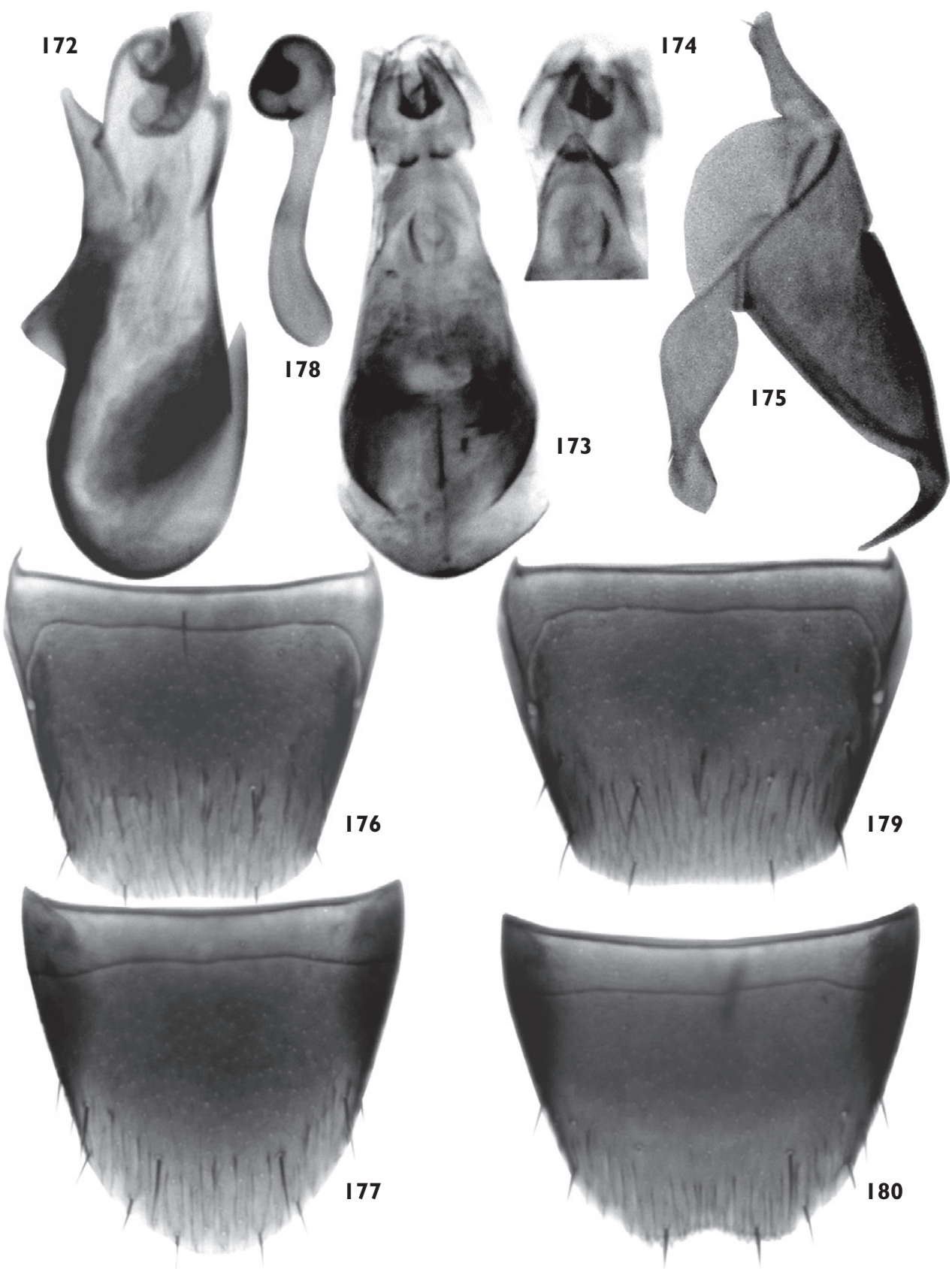

Figs 172-180. Genital structures of Gnypeta saccharina: 172, median lobe of the aedeagus in lateral view, 173 , dorsal view, 174 , apical part of median lobe in ventral view; 175 , paramere; 176 , male tergite $8 ; 177$, male sternite $8 ; 178$, spermatheca; 179 , female tergite $8 ; 180$, female sternite 8 . 
(also in direct sun) on the shore of the Saint John River, and some from drift material, mostly maple seeds, in the Saint John River. The adults were diurnally active and in company with various Bembidion and Tachyusa species. Collecting period: May, June and July.

\section{Comments}

Gnypeta nigrella differs from G. brevicornis and G. uteana by moderately elongate basal article of metatarsus, which is extremely elongate in the two latter species. It differs from other Gnypeta species by its slender body, and almost total lack of punctation in the first three visible tergal impressions.

\section{Gnypeta saccharina Klimaszewski and Webster, sp. nov.} urn:lsid:zoobank.org:act:3F61ACAE-3402-4A0B-8464-78A52DF9AEA5

(Figs 19, 37 a, b, 172-180, 199)

HOLOTYPE (male): CANADA, New Brunswick, Queens Co., Canning Grand Lake near Scotchtown, $45.8762^{\circ}$ N. $66.1817^{\circ}$ W., 25.V.2006, R.P. Webster coll.; silver maple swamp near lake margin, margin of vernal pond in moist leaves, IRM No. 1 (LFC). PARATYPES: New Brunswick, York Co., Fredericton, at Saint John River, $45.9588^{\circ} \mathrm{N}, 66.6254^{\circ}$ W., 7.VI.2005, R.P. Webster coll., margin of river in flood debris (LFC, RWC) 3 females.

\section{Etymology}

The specific name "saccharina" derives from the Latin specific name of silver maple, Acer saccharinum L., in reference to the forest type where the holotype was captured.

\section{Diagnosis}

This species can be recognized by the following combination of characters: body length 2.4-2.7 mm (Fig. 19); elytra at suture as long as pronotum and about $1 / 6$ wider than maximum width of pronotum (Fig. 19); abdomen at base slightly narrower than elytra and subparallel, tergal impressions without coarse punctation (Fig. 19); antennal article 4 strongly elongate, 5-7 moderately elongate, 8-10 subquadrate (Figs 37 a, b); median lobe of aedeagus with apical part narrowly triangularly produced with slightly sinuate edges in lateral view (Fig. 172); spermatheca pipe-shaped, capsule spherical with large apical invagination, stem narrowly elongate and sinuate (Fig. 178); male tergite 8 truncate apically (Fig. 176); female sternite 8 with large apical emargination (Fig. 180). The subquadrate antennal articles 7-10; distinct shape of spermatheca; medially emarginated female sternite 8 , and the shape of the apical portion of the median lobe of the aedeagus are the best characters for recognition of this species.

\section{Description}

Body length 2.4-2.7 mm; dark brown (Fig. 19); integument moderately glossy; pubescence yellowish grey and very short and dense; antennal articles 5-7 moderately 
elongate, 8-10 subquadrate (Figs $37 \mathrm{a}, \mathrm{b}$ ); head slightly narrower than pronotum (Fig. 19); elytra and abdomen (less so) wider than either head or pronotum; head rounded posteriorly; pronotum broadest in the middle, pubescence directed obliquely posterolaterad from the midline; elytra at suture as long as pronotum and about $1 / 6$ wider than maximum width of pronotum, pubescence directed obliquely postero-laterad, in weak wavy pattern medially on each side of disc (Fig. 19); abdomen subparallel, distinctly narrower than elytra at base (Fig. 19); metatarsus with basal article slightly longer than the following article. Male. Tergite 8 truncate apically (Fig. 176). Sternite 8 elongate and broadly rounded apically (Fig. 177). Median lobe of aedeagus with narrowly triangular apex in lateral view (Fig. 172); bulbus moderately large in dorsal view (Fig. 173); internal sac with complex structures as illustrated (Figs 172, 173). Female. Tergite 8 truncate apically (Fig. 179). Sternite 8 broadly rounded posteriorly with deep V-shaped apical emargination (Fig. 180). Spermatheca club-shaped, capsule spherical apically and constricted basally, connected to a narrow tubular and sinuate stem (Fig. 178).

Distribution (Fig. 199)

Gnypeta saccharinum was described from two localities in New Brunswick and these are the only known localities for this species.

\section{Collection and habitat data}

Adults were captured in May from moist leaves near margin of vernal pond in silver maple (Acer saccharinum L.) swamp, and in June from flood debris at the margin of the Saint John River.

\section{Gnypeta minuta Klimaszewski and Webster, sp. nov.}

urn:lsid:zoobank.org:act:34D54632-2C6C-426C-8C85-C205C3004FDD

(Figs 20, 38 a, b, 181-189, 193)

HOLOTYPE (male): CANADA, New Brunswick, York Co., Douglas, Keswick River at Rt. $105,45.9943^{\circ}$ N., $66.8337^{\circ}$ W., 18.06.2004, R.P. Webster coll., silver maple forest, under debris on muddy soil near small pool, IRM No. 2 (LFC). PARATYPE (female): CANADA: New Brunswick, Restigouche Co., Little Tobique River near Red Brook, $47.4465^{\circ}$ N., 67.0689 W., 13.06.2006, R.P. Webster coll., river margin, under debris on clay and sand mix (LFC).

\section{Etymology}

The name of this species is the Latin "minuta", meaning small, in reference to the small size of this species.

\section{Diagnosis}

This species can be recognized by the following combination of characters: body length $2.3 \mathrm{~mm}$ (Fig. 20); elytra at suture longer than pronotum and about $1 / 6$ wider than maximum width of pronotum (Fig. 20); abdomen at base distinctly narrower than 


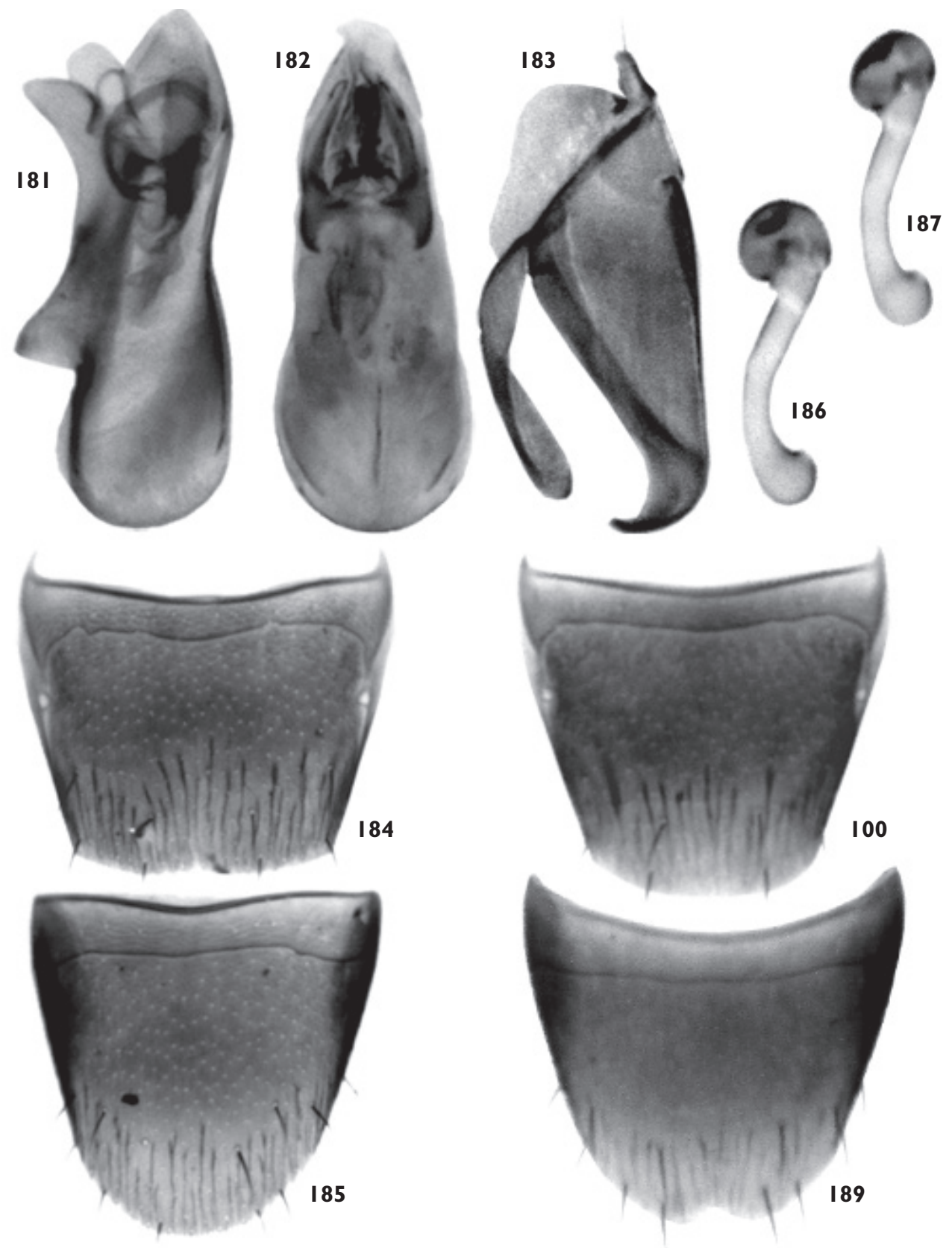

Figs I 8 I-189. Genital structures of Gnypeta minuta: 181, median lobe of the aedeagus in lateral view, 182 , dorsal view; 183 , paramere; 184 , male tergite $8 ; 185$, male sternite $8 ; 186,187$, spermatheca; 188 , female tergite $8 ; 189$, female sternite 8 . 
elytra and broadening posteriorly, tergal impressions with coarse punctation (Fig. 20); antennal article 4 strongly elongate, 5-7 moderately elongate, 8-10 subquadrate (Figs $38 \mathrm{a}, \mathrm{b}$ ); median lobe of aedeagus with apical part broadly triangular in lateral view (Fig. 181); male tergite 8 truncate apically (Fig. 184). The subquadrate antennal articles $7-10$, posteriorly broadening abdomen, and distinct shape of the apical portion of the median lobe of the aedeagus, slightly emarginated apex of female sternite 8 and the pipe-shaped spermatheca are the best characters for recognition of this species.
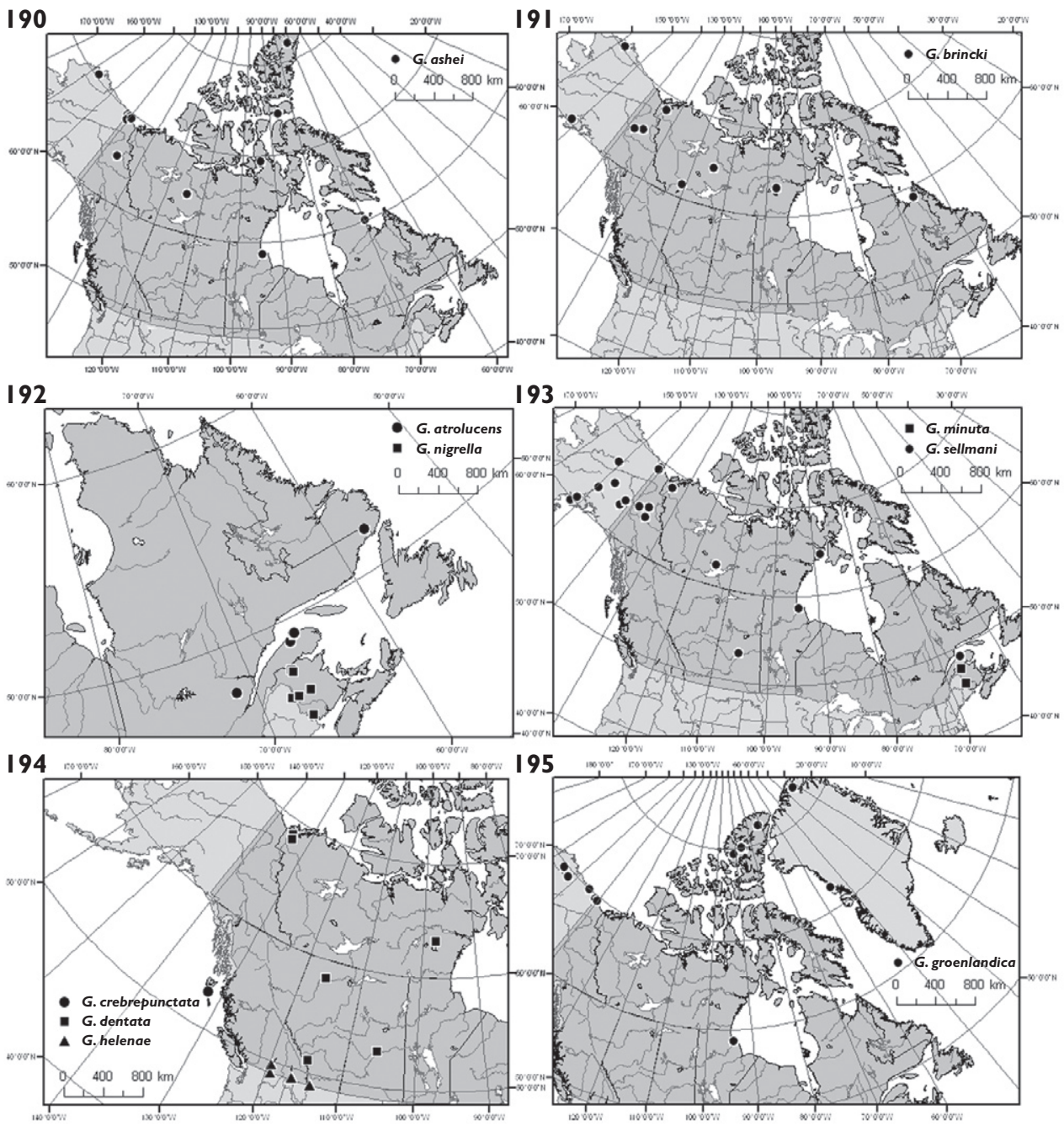

Fig. 190. Collection localities in Canada and Alaska of G. ashei.

Fig. 1 91. Collection localities in Canada and Alaska of G. brincki.

Fig. 192. Collection localities in Canada of $G$. atrolucens and $G$. nigrella.

Fig. 193. Collection localities in Canada and Alaska of G. minuta and G. sellmani.

Fig. 194. Collection localities in Canada of G. crebrepunctata, G. dentata, and G. helenae.

Fig. 195. Collection localities in Canada and Alaska of G. groenlandica. 

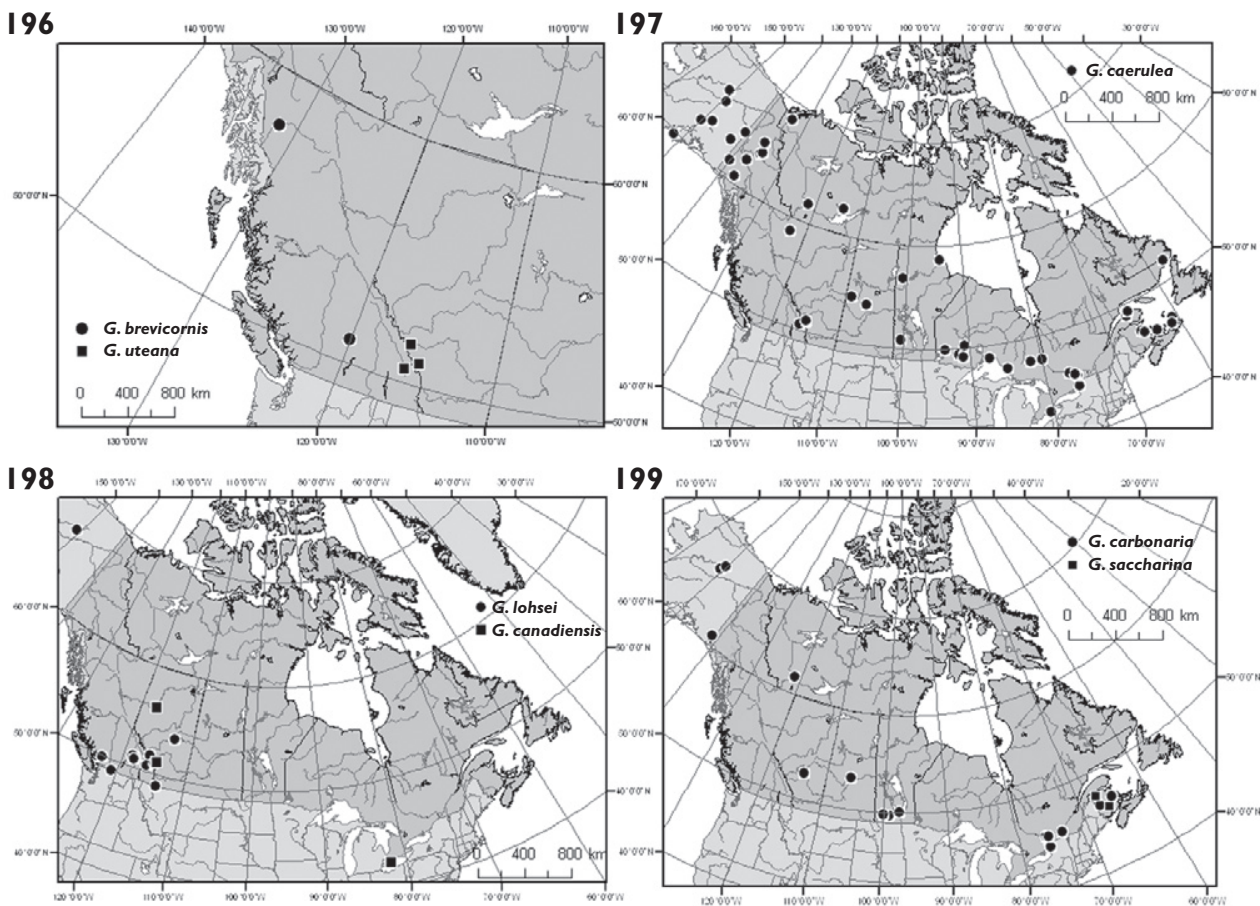

Fig. 196. Collection localities in Canada of G. brevicornis and G. uteana.

Fig. 197. Collection localities in Canada and Alaska of G. caerulea.

Fig. 198. Collection localities in Canada and Alaska of G. lobsei and G. canadiensis.

Fig. 199. Collection localities in Canada and Alaska of G. carbonaria and G. saccharina.

\section{Description}

Body length $2.3 \mathrm{~mm}$; dark brown (Fig. 20); integument moderately glossy; pubescence yellowish grey and moderately short and dense; antennal articles 5-7 moderately elongate, 8-10 subquadrate (Figs 38 a, b); head slightly narrower than pronotum (Fig. 20); elytra and abdomen (less so) wider than either head or pronotum; head rounded posteriorly; pronotum broadest in the apical third, pubescence directed obliquely posterolaterad from the midline; elytra at suture longer than pronotum and about $1 / 6$ wider than maximum width of pronotum, pubescence directed obliquely postero-laterad, in weak wavy pattern medially on each side of disc (Fig. 20); abdomen broadening posteriorly, distinctly narrower than elytra at base (Fig. 20); metatarsus with basal article slightly longer than the following article. Male. Tergite 8 truncate apically (Fig. 184). Sternite 8 elongate and broadly rounded apically (Fig. 185). Median lobe of aedeagus with broadly triangular apex in lateral view (Fig. 181); bulbus moderately large in dorsal view (Fig. 182); internal sac with complex structures as illustrated (Figs 181, 182). Female. Tergite 8 broadly rounded apically (Fig. 188); sternite 8 with shallow median emargination at apex (Fig. 189); spermatheca pipe-shaped (Figs 186, 187). 
Distribution (Fig. 193)

Gnypeta minuta is known only from New Brunswick, Canada.

\section{Collection and habitat data}

The two specimens were captured in June, one from under debris on muddy soil near a small pool in a silver maple forest, and the other from under debris on clay and sand mix at river margin.

\section{Acknowledgements}

We thank the following colleagues for their help in arranging loans of types and ordinary specimens: D. Furth and G. Havel (USNM), A. Davies (CNC), G. Gillerfors (Varberg, Sweden), R. Danielsson (MZL), P.D Perkins (MCZ), and C. Majka (NSM). We appreciate the assistance of P. Cheers (LFC) with editing the manuscript and D. Paquet with formatting it. We appreciate the support of our research director G. Daoust (LFC), and J. Sweeney (CFS, AFC) for reviewing and improving the first draft of this manuscript.

\section{References}

Ashe JS (2001) Keys to the tribes and genera of Nearctic Aleocharinae. In: Arnett RH, Thomas MC (Eds) American Beetles. 1. Archostemata, Myxophaga, Adephaga, Polyphaga: Staphyliniformia. CRC Press LLC, Boca Raton, Florida, 299-374.

Bernhauer M (1905) Folge neuer Staphyliniden der paläarktischen Fauna, nebst Bemerkungen. Verhandlungen der Kaiserlich-Königlichen Zoologisch-Botanischen Gesellschaft in Wien 55: 580-595.

Bernhauer M, Scheerpeltz O (1926) Coleopterorum Catalogus, 82, Staphylinidae 6. W. Junk, Berlin, 499-988.

Blackwelder RE (1952) The generic names of the beetle family Staphylinidae with an essay on genotypy. Bulletin of the United States National Museum 200: I-IV, 1-483.

Bland JHB (1865) Compiled descriptions of North American Staphylinidae. Proceedings of the Entomological Society of Philadelphia 4: 391-425.

Brundin L (1929) Eine neue Gnypeta aus dem Torneträskgebiete (Col. Staphylinidae). Entomologisk Tidskrift 50: 14-15, pl. 1.

Campbell JM, Davies A (1991) Family Staphylinidae. Rove beetles. In: Bousquet Y (Ed) Checklist of beetles of Canada and Alaska. Agriculture Canada Publication 1861/E: 86-124.

Casey TL (1885) New genera and species of Californian Coleoptera. Bulletin of the California Academy of Sciences 1: 285-336.

Casey TL (1886) Descriptive notices of North American Coleoptera. Bulletin of the California Academy of Sciences 6: 157-264.

Casey TL (1894) Coleopterological notices. V. Annals of the New York Academy of Sciences 7: 281-606. 
Casey TL (1906) Observations on the staphylinid groups Aleocharinae and Xantholinini, chiefly of America. Transactions of the Academy of Sciences of St. Louis 16: 125-434.

Casey TL (1910) New species of the staphylinid tribe Myrmedoniini. Memoirs on the Coleoptera 1. New Era Printing Co., Lancaster, Pennsylvania.

Casey TL (1911) New American species of Aleocharinae and Myllaeninae. Memoirs on the Coleoptera 2. New Era Printing Co., Lancaster, Pennsylvania.

Downie NM, Arnett RH (1996) The beetles of northeastern North America. Volume 1. The Sandhill Crane Press, An American Insect Project, Gainesville, Florida.

Erichson WF (1839) Erster Band. Genera et species Staphylinorum insectorum coleopterorum familiae. F.H. Morin, Berlin, 400 pp.

Gouix N, Klimaszewski J (2007) Catalogue of aleocharine rove beetles of Canada and Alaska (Coleoptera, Staphylinidae, Aleocharinae). Pensoft Publishers, Sofia-Moscow, 166 pp.

Hyman PS, Parsons MS (1994) A review of scarce and threatened Coleoptera of Great Britain. Part 2. UK Nature Conservation 12.

ICZN (1957) Opinion 463. Designation under the pletomed usage for the genus "Oxypoda" Mannerheim, 1831 (Class Insecta, Order Coleoptera). Opinions and Declarations Rendered by the International Commission on Zoological Nomenclature, 16: 15-24.

Klimaszewski J (1984) A revision of the genus Aleochara Gravenhorst of America north of Mexico (Coleoptera: Staphylinidae, Aleocharinae). Memoirs of the Entomological Society of Canada 129: 3-211.

Klimaszewski J, Pelletier G (2004) Review of the Ocalea group of genera (Coleoptera, Staphylinidae, Aleocharinae) in Canada and Alaska: new taxa, bionomics, and distribution. The Canadian Entomologist 136: 443-500.

Klimaszewski J, Winchester NN (2002) Aleocharine rove beetles (Coleoptera Staphylinidae) of the ancient Sitka spruce forest on Vancouver Island, British Columbia, Canada. Mémoires de la Société royale belge d'Entomologie 40: 3-126.

Klimaszewski J, Sweeney J, Price J, Pelletier G (2005) Rove beetles (Coleoptera: Staphylinidae) in red spruce stands, eastern Canada: diversity, abundance, and descriptions of new species. The Canadian Entomologist 137: 1-48.

LeConte JL (1863) New species of North American Coleoptera. Smithsonian Miscellaneous Collections 6: 1-56.

Lohse GA (1974) Die Käfer Mitteleuropas. In: Freude H, Harde KW, Lohse GA (Eds). Band 5: Staphylinidae II (Hypocyphtinae und Aleocharinae) Pselaphidae. Goecke \& Evers, Krefeld.

Lohse GA (1989a) Staphylinidae II (Hypocyphtinae und Aleocharinae). In: Lohse GA, Lucht WH (Ed). Die Käfer Mitteleuropas. Band 12. Supplementband mit Katalogteil. Goecke \& Evers, Krefeld.

Lohse GA (1989b) Gnypeta groenlandica sp. n., eine neue Staphylinide aus Grönland. Entomologische Blätter 85: 58-60.

Majka CG, Klimaszewski J (2008) Introduced Staphylinidae (Coleoptera) in the Maritime Provinces of Canada. The Canadian Entomologist 140: 48-72.

Mannerheim CG (1830) Précis d'un nouvel arrangement de la famille des brachélytres de l'ordre des insectes coléoptères. Mémoires de l'Académie Impériale des Sciences de St.-Pétersburg 1: 415-501. Sep. St. Petersburg, 87 pp. 
Moore I., Legner EF (1975) A catalogue of the Staphylinidae of America north of Mexico (Coleoptera). University of California Division of Agricultural Sciences. Special Publication No. 3015: 1-514.

Muona J (1984) Review of Palaearctic Aleocharinae also occurring in North America (Coleoptera: Staphylinidae). Entomologica Scandinavica 15: 227-231.

Newton AF, Thayer MK (1992) Current classification and family-group names in Staphyliniformia (Coleoptera). Fieldiana Zoology New Series 67: I-III, 1-92.

Palm T (1966) De svenska Gnypeta-arterna (Col. Staphylinidae, Aleocharinae). Entomologisk Tidskrift 87: 136-141.

Paśnik G (2002) Four new species of the genus Gnypeta Thomson, 1858 from the Oriental Region (Coleoptera, Staphylinidae, Aleocharinae). Revue Suisse de Zoologie 109: 705-713.

Paśnik G (2006a) A revision of the World species of the genus Tachyusa Erichson, 1837 (Coleoptera, Staphylinidae: Aleocharinae). Zootaxa 1146: 1-152.

Paśnik G (2006b) Taxonomy and phylogeny of the World species of the genus Ischnopoda Stephens, 1837 (Coleoptera, Staphylinidae: Aleocharinae). Zootaxa 1179: 1-96.

Paśnik G (2007) Revision and phylogenetic analysis of the African genus Ischnopoderona (Scheerpeltz, 1974) new status (Coleoptera, Staphylinidae, Aleocharinae). Zootaxa 1412: 1-54.

Sahlberg CR (1830) Insecta Fennica, dissertationibus academicis, A. 1817-1834 Editis. Pars 19: 281-360. J.C. Frenckel, Helsingfors.

Seevers CH (1978) A generic and tribal revision of the North American Aleocharinae (Coleoptera: Staphylinidae). Fieldiana Zoology 71: i-vi, 1-289.

Smetana A (2004) Subfamily Aleocharinae Fleming, 1821 In: Löbl I, Smetana A (Eds) Catalogue of Palaearctic Coleoptera, Vol. 2. Apollo Books, Stenstrup. 353-494.

Thomson CG (1858) Försök till uppställining af Sveriges Staphyliner. Öfversigt af Köngliga Vetenskaps-Akademiens Förhandlingar 15: 27-40.

Thomson CG (1859) Skandinaviens Coleoptera, synoptiskt bearbetade. Vol. 1. Berlingska Boktryckeriet, Lund.

Yosii R, Sawada K (1976) Studies on the genus Atheta Thomson and its allies (Coleoptera, Staphylinidae). II. Diagnostic characters of genera and subgenera with description of representative species. Contributions of the Biological Laboratory, Kyoto University 25: 11-140.

\section{Appendix A. List of specimens examined}

Types are listed under each species in the text, except for long lists of paratypes, which are given here. Species are listed in alphabetical order.

\section{A1. Gnypeta ashei Klimaszewski, sp. nov.}

\section{Paratypes}

UNITED STATES: Alaska: Atkasuk, North Slope, 17.VI.1978, B. Vogel (CNC) 9 males, 3 females; (LFC) 2 males, 2 females. CANADA: Manitoba: Churchill, 
13.VI.1952, J.G. Chillcott (CNC) 1 male. Northwest Territories: Spence Bay, 2.VII.1951, J.G. Chillcott (CNC) 1 male, 1 sex?; Ellesmere Island, Hazen Camp, 10.VIII.1961, D.R. Oliver (CNC) 1 male; 10.VIII.1961, D.R. Oliver (CNC) 6 males, 12 females, 1 sex?; (LFC) 1 female; 13.VIII.1961 (CNC) 1 female; 15.VII.1961 (CNC) 5 males, 8 females, 2 sex?; (LFC) 1 female, 1 sex?; 17.VII.1961 (CNC) 2 females; 19.VIII.1961 (CNC) 1 male, 4 females; (LFC) 1 male; Ellesmere

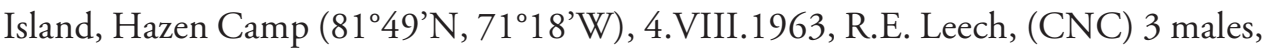
3 females; 5.VII.1963 (CNC) 3 males, 3 females; 7.VII.1963 (CNC) 2 females; 8.VIII.1963 (CNC) 1 female; 11.VII.1963 (CNC) 1 male, 2 females; 12.VIII.1963 (CNC) 1 female; same data except Trap 20 (CNC) 1 female; 15.VII.1963 (CNC) 1 male, 1 female; 19.VII.1963 (CNC) 4 males; (LFC) 3 females; 19.VIII.1963 (CNC) 11 males, 5 females; same data except Trap 13 (CNC) 1 female; 21.VII.1963 (CNC) 1 male, 1 female; 23.VII.1963 (CNC) 1 male, 1 female; same data except Trap 41 (CNC) 1 female; 27.VII.1963, Trap 11 (CNC) 1 female; 27.VII.1963 Trap 18 (CNC) 1 female; 31.VII.1963 (CNC) 6 males, 2 females; (LFC) 1 male, 1 female; Ellesmere Island, Hazen Camp ( $\left.81^{\circ} 49^{\prime} \mathrm{N}, 71^{\circ} 18^{\prime} \mathrm{W}\right), 22 . \mathrm{VI} .1966$, Corbet $\&$ Nettleship, marsh (CNC) 1 male, 1 sex?; Salmita Mines $\left(64^{\circ} 05^{\prime} \mathrm{N}, 111^{\circ} 15^{\prime} \mathrm{W}\right)$, 20.VI.1953, J.G. Chillcott (CNC) 1 male; Devon Island, 1 mi. S. Camp $\left(75^{\circ} \mathrm{N}\right.$, $\left.85^{\circ} \mathrm{W}\right)$, 23.VI.1971, J.K. Ryan \& C.R. Hergert, I.B.P. Proj., On snow (CNC) 1 male. Québec: Payne Bay, 5.VI.1958, E.E. MacDougall (CNC) 1 female. Yukon:

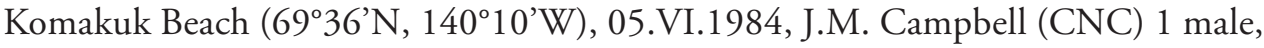
4 females; 15.VI.1984 (CNC) 1 female; Clarence Lagoon $\left(69^{\circ} 38^{\prime} \mathrm{N}, 140^{\circ} 55^{\prime} \mathrm{W}\right)$, 05.VII.1984, J.M. Campbell, sifting litter on shore (CNC) 1 female; Dempster Hwy mi. 65, 3300', 13.VII.1968, Campbell \& Smetana, (CNC) 1 male; British Mts., Swan Pond, 340 m, 4 km NE Wolf Cr. (69 $\left.08^{\prime} \mathrm{N}, 140^{\circ} 14^{\prime} \mathrm{W}\right)$, 23.VI.1984, J.M. Campbell, treading sedges around edge of pond (CNC) 1 male, 1 female, 1 sex?; Herschel Island, 27.VII.1971, W.R.M. Mason (CNC) 1 female.

\section{A2. Gnypeta atrolucens Casey}

\section{Non-type material}

CANADA: Québec: Québec, Mont Albert, Parc Gaspésie, 8.VII.1972, J.M. \& B.A. Campbell (CNC) 1 male; Gaspésie, Parc Gaspésie, Mont Albert, 1000', 8.VII.1972, J.M. \& B.A. Campbell (CNC) 2 males, 1 sex?; 9.VII.1972 (CNC) 1 male, 1 female; (LFC) 1 male, 1 sex?; Gaspésie, Rivière-à-Claude, 4 mi. S., 200', 18.VII.1972, J.M. Campbell (CNC) 1 male, 3 females, 1 sex?; Laurentides, Parc des Laurentides, Bois Vert, 2800', 18.VIII.1970, J.M. \& B.A. Campbell (CNC) 2 males; (LFC) 1 female, 2 sex?; Gaspésie, Mont-St-Pierre, 21.VII.1972, J.M. Campbell (CNC) 1 female, 1 sex?; (LFC) 1 male. Newfoundland and Labrador: Labrador, SE Labrador, L'Anse au Loup, 17.VII.1951, Lindroth, No. 295 (CNC) 1 male, 1 female. 


\section{A3. Gnypeta brevicornis Casey}

\section{Paralectotypes}

CANADA: British Columbia: Br. C. [British Columbia]; brevicornis - 2, Paratype USNM 38865, Casey bequest 1925 (USNM) 1 sex?; Glenora B.C.; brevicornis - 3, Paratype USNM 38865; Casey bequest 1925 (USNM) 1 sex?; Br. C. [British Columbia]; brevicornis - 4, Paratype USNM 38865, Casey bequest 1925 (USNM) 1 female; Glenora B.C.; brevicornis - 5, Paratype USNM 38865; Casey bequest 1925 (USNM) 1 sex?; Glenora B.C.; brevicornis - 6, Paratype USNM 38865; Casey bequest 1925 (USNM) 1 sex?; Kamloops B.C.; brevicornis - 7, Paratype USNM 38865; Casey bequest 1925 (USNM) 1 sex?; Kamloops B.C., Wickham; brevicornis - 8, Paratype USNM 38865; Casey bequest 1925 (USNM) 1 female; Br. C. [British Columbia]; brevicornis - 10, Paratype USNM 38865, Casey bequest 1925 (USNM) 1 sex?; Br. C. [British Columbia]; brevicornis - 11, Paratype USNM 38865, Casey bequest 1925 (USNM) 1 male. Present designation.

\section{A4. Gnypeta brincki Palm}

\section{Non-type material}

UNITED STATES: Alaska: Kenai Pen., 6.VI.1978, Clam Gulch, Smetana \& Becker (CNC) 1 female; 3 mi. SE Kenai, 7.VI.1978, Smetana \& Becker (CNC) 1 male, 1 female, 2 sex?; 8.VI.1978 (CNC) 1 male, 2 females, 1 sex?; Atkasuk, North Slope, 17.VI.1978, B. Vogel (CNC) 1 female. CANADA: Northwest Territories: Spence River, 38 mi. SE Fort Simpson, 19.VI.1972, A. Smetana (CNC) 1 sex?; Salmita Mines $\left(64^{\circ} 05^{\prime} \mathrm{N}, 111^{\circ} 15^{\prime} \mathrm{W}\right), 20$. VI.1953, J.G. Chillcott (CNC) 1 female; Ford Lake, 23.VI.-4.VII.1966, G.E. Shewell (CNC) 1 female; Inuvik, 29.VI.1972, A. Smetana (CNC) 1 male. Québec: Nunavik, Koroc River, 10.VIII.1986, Estuary 1-2 m above tide, moist/dry substrate of sand-gravel, organic mats., A. \& S. Morgan (CNC) 1 female. Yukon: Dempster Hwy mi. 65, 3300', 13.VII.1968, Campbell \& Smetana (CNC) 1 female; North Fork Pass, Dempster Hwy mi. 53, 4200', 24.VII.1978, A. Smetana \& J.M. Campbell (CNC) 11 females, 13 males, 16 sex?; (LFC) 2 males, 5 females, 2 sex?

\section{A5. Gnypeta caerulea (C.R. Sahlberg)}

\section{Non-type material}

UNITED STATES: Alaska: Kenai Pen., 1 mi. N. Anchor Pt., 200', 2.VI.1978, Smetana \& Becker (CNC) 1 female; Prudhoe Bay Rd., Bonanza Cr. , 900' $\left(150^{\circ} 40^{\prime}\right.$, $\left.66^{\circ} 40^{\prime}\right)$ 2.VII.1978, A. Smetana \& J.M. Campbell (CNC) 1 female; Prudhoe Bay Rd., 8 mi. N.S. Fork Koyukuk R., 1000' $\left(67^{\circ} 13^{\prime} \mathrm{N}, 150^{\circ} 07^{\prime} \mathrm{W}\right)$ 8.VIII.1978, A. Smetana \& J.M. Campbell (CNC) 1 female; (LFC) 1 male; Mi. 1252 Alaska Hwy., 7.VII.1968, 
J.M. Campbell \& A. Smetana (CNC) 1 female; Mi. 27, Taylor Hwy., 8.VII.1968, J.M. Campbell \& A. Smetana (CNC) 1 sex?; Mi. 123 Taylor Hwy., 9.VII.1968, J.M. Campbell \& A. Smetana (CNC) 1 female; Mi. 24 Wales Hwy., Hess Cr, 600' $\left(65^{\circ} 40^{\prime} \mathrm{N}, 149^{\circ} 10^{\prime} \mathrm{W}\right), 10 . \mathrm{VII} .1978$, J.M. Campbell \& A. Smetana (CNC) 2 females; Mi. 110 Denali Hwy., Seattle Cr., 12.VII.1978, J.M. Campbell \& A. Smetana (CNC) 4 males, 2 females; same data except 15.VII.1978 (CNC) 1 sex?; Denali St. Pk., Byers Cr., at Hwy 1, 20.VI.1978, A. Smetana \& E. Becker (CNC) 1 female; Denali St. Pk., Byers Lk. Cpgd., 26.VI.1978, A. Smetana \& E. Becker (CNC) 1 female. CANADA: Alberta: Kananaskis F.E.S., 1.VIII.1971, J.M. \& B.A. Campbell (CNC) 1 male; (LFC) 1 male; Kananaskis F.E.S., Lust Creek, 20.VI.1971, J.M. \& B.A. Campbell (CNC) 1 sex?; Highwood Pass, 35 mi. S. Kananaskis, 7000', 28.VII.1970, E.E. Lindquist (CNC) 1 male; 10 mi. SW. Kananaskis F.E.S., 31.VII.1971, J.M. \& B.A. Campbell (CNC) 4 sex?; (LFC) 1 male, 1 female. British Columbia: Mile 496, Alaska Hwy., 10.VII.1979, B.F \& J.L. Carr, Lot 2 (CNC) 1 female. Manitoba: Churchill, 4.VI.1952, J.G. Chillcott (CNC) 1 female; Riding Mtn. N.P, nr. McKinnon Lake, 5.IX.1979, A. Smetana, (CNC) 1 female, 2 sex?; (LFC) 1 female; Riding Mtn. N.P, Swanson Cr. at Hwy. 19, 7.IX.1979, A. Smetana (CNC) 1 sex?; 4 mi. SE North Pole, 30.VI.1978, A. Smetana \& J.M. Campbell (CNC) 1 sex?. New Brunswick: Kouchibouguac, 21.IX.1977, A. Smetana, Code-6012F (CNC) 1 sex? (LFC) 1 female; 30.V.1977, S.J. Miller, Code-5169a (CNC) 1 sex?; Northumberland Co., N.W. Miramichi R., 24.VI.1962, J. Marshall (CNC) 1 sex?. Nova Scotia: Inverness Co., 17.V.1996, J. MacMillan (CBU) 1 sex?; Cape Breton, Lone Shielding, 4.VII.1983, Malaise trough, R. Vockeroth, PG729861 (CNC) 1 male, 2 females; Lone Shielding, 60 m, 15.IX.1984, Moss along stream, J.M. Campbell \& A. Davies, PG730860 (CNC) 1 female; H.N.P., $2 \mathrm{~km}$ NE Ingonish Bch, 20.IX.1984, tread edge of pond with sphagnum, J.M. Campbell \& A. Davies, PG990692 (CNC) 1 female. Northwest Territories: Hwy. 4 crossing Cameron R., 19.VII.1981, B.F. \& J.L. Carr, Lot 5 (CNC) 1 female; Ft. Simpson, 10.VI.1972, A. Smetana (CNC) 2 males, 2 females; Rabbitskin R. 23 mi. SE Ft. Simpson, 19.VI.1972, A. Smetana (LFC) 1 female; Inuvik, 24.VI.1972, A. Smetana (CNC) 1 female; Inuvik, 25.VI.1972, A. Smetana (CNC) 1 male, 1 female; Unnamed Lake, 18 mi. NW Inuvik via East Channel, 26.VI.1972, A. Smetana (CNC) 2 males, 1 sex?. Ontario: Ottawa, Mer Bleue bog, 11.VIII.1982, A. Davies (CNC) 1 sex?; Lk. Superior Prov. Pk., Lake Mijinemungshing, 12.VI.1973, J.M. Campbell \& R. Parry (CNC) 1 sex?; 9 mi. E. Terrace Bay, 14.VI.1973, Campbell \& Parry (CNC) 1 sex?; Ignac, 16.VI.1973, Campbell \& Parry (CNC) 1 sex?; English River, 16.VI.1973, Campbell \& Parry (CNC) 5 sex?; (LFC) 1 sex?; Moose Creek, 10 mi. S. Sioux Lookout, 17.VI.1973, Campbell \& Parry (CNC) 1 female, 6 sex?; (LFC) 1 male; 16 mi. S. Savant Lake, 23.VI.1973, Campbell \& Parry (CNC) 1 female, 3 sex?; 52 mi. S. Armstrong, 27.VI.1973, R. Parry \& J.M. Campbell (CNC) 1 female; Turkey Point, 24.VII.1984, Sweeping in marshy area, LL 6, L. LeSage (CNC) 1 sex?; St. Lawrence Is. Nat. Park, Grenadier I. Center, 29.V.1975, Code1-4330, A. Davies (CNC) 1 sex?; Sudbury Co., Mattagami, 28.VIII.1980, R. Baranowski (LUC) 1 female; Carleton Co., Mer Bleue, 17.IX.1980, R. Baranowski (LUC) 1 female. Prince Edward 
Island: Queens Co., St. Patricks, 21.VII.2001, C.G. Majka, along stream (CGMC) 1 male, 1 female; same data except: 18.VIII.2002 (CGMC) 1 sex?. Québec: Gaspésie, Parc Gaspésie, Mont Albert, 1000’, 8.VII.1972, J.M. \& B.A. Campbell (CNC) 2 females, 4 sex?; Gaspésie, Parc Gaspésie, Lac Ste-Anne, 1500’, 12.VII.1972, J.M. \& B.A. Campbell (CNC) 1 female; Gaspésie, Rivière-à-Claude, 4 mi. S, 200', 18.VII.1972, J.M. Campbell (CNC) 2 males, 1 female, 2 sex?; Fort Coulonge, 19.VI.1976, J.M. Campbell (CNC) 1 sex?; Gatineau, Gatineau Pk., Ramsay Lk., 20.VII.1982, Davies, Smetana \& Vermette (CNC) 1 male, 1 sex?; Gatineau, Gatineau Pk., Ramsay Lake Area., 21.VI.1970, J.M. Campbell (LFC) 1 male; Gatineau, Gatineau Pk., Lac Pinks, 21.VII.1982, veg. beaver pond, L. LeSage (CNC) 5 sex?; (LFC) 1 sex?. Saskatchewan: Meadow Lk. Prov. Pk., 20.VII.1972, D.E. Bright (CNC) 3 males, 8 sex?; (LFC) 1 sex?; Prince Albert N.P., 24.VII.1972, D.E. Bright (CNC) 1 sex?. Newfoundland and Labrador: Labrador, SE Labrador, L'Anse au Loup, 17.VII.1951, Lindroth, No. 295 (CNC) 1 male. Yukon: Alaska Hwy., Edith Creek, 6.VII.1968, Campbell \& Smetana (CNC) 1 female; Dempster Hwy mi. 65, 3300’, 13.VII.1968, Campbell \& Smetana (CNC) 4 males; Dempster Hwy mi. 37, 3000', 14.VII.1968, Campbell \& Smetana (CNC) 1 male; Dempster Hwy mi. 154; Ogilvie R., 1900', 20.VII.1978, Campbell \& Smetana (CNC) 2 males, 2 females, 1 sex?; Dempster Hwy mi. 136, 1900', 22.VII.1978, Campbell \& Smetana (CNC) 1 male, 3 sex?; Hansen Lk., 9 mi. SW Keno, 17.VII.1968, Campbell \& Smetana (CNC) 2 males; $11 \mathrm{mi}$. W Elsa, 18.VII.1968, Campbell \& Smetana (CNC) 1 female; (LFC) 1 female; McQuesten Lk., 15 mi. SW Keno, 19.VII.1968, Campbell \& Smetana (CNC) 1 female.

\section{A6. Gnypeta canadensis Klimaszewski}

\section{Paratypes}

CANADA. Alberta: Ft. Macleod, 16.III.1980, B.F. \& J.L. Carr, PARATYPE, Lot 3 (CNC) 2 females; Ft. Macleod, 16.III.1980, B.F. \& J.L. Carr, Lot 3 (CNC) 2 males; Ghost Dam, 28.III.1953, B.F. \& J.L. Carr, Lot 1 (CNC) 1 male; Ontario: Rondeau Pr. Pk., South Point, 2.VI.1985, A. Davies \& J.M. Campbell (CNC) 1 male; Rondeau Pr. Pk., 2-6.VI.1985, L. LeSage \& A. Smetana (CNC) 1 sex?; Rondeau Pr. Pk., 2-6. VI.1985, L. LeSage \& A. Smetana, int. trap, open marsh forest (LFC) 1 female; Rondeau Pr. Pk., 28.V-2.VI.1985, L. LeSage \& A. Smetana (CNC) 1 female.

\section{A7. Gnypeta carbonaria Mannerheim}

\section{Non-type material}

UNITED STATES: Alaska: Prudhoe Bay Rd., Bonanza Cr., 900' (6640’N, 15040’W), 2.VII.1978, A. Smetana \& J.M. Campbell (CNC) 2 females; Prudhoe Bay Rd. 8 mi. N.S. Fort Koyukuk R., 1000' (67¹3’N, 15007’W), 8.VIII.1978, A. Smetana \& J.M. Campbell (CNC) 1 male, 3 females; Mi. 1252 Alaska Hwy., 7.VII.1968, Campbell 
\& Smetana (CNC) 2 females, 1 sex?. CANADA: Alberta: 2 mi. S. Ponaka, Battle R., 6.VIII.1976, J.M. Campbell (CNC) 1 male, 1 female. Manitoba: Spruce Woods P.P., 5.VII.1985, Y. Bousquet (CNC) 1 male; Brandon, 12.VIII.1958, R.B. Madge (CNC) 1 female; Stonewall, 18.VIII.1918, in rotten fungus, J.B. Wallis (CNC) 1 female. New Brunswick: York Co., Fredericton, at St. John River $\left(45.9588^{\circ} \mathrm{N}, 66.6254^{\circ} \mathrm{W}\right)$, 4.VII.2004, R.P. Webster, margin of river in drift material (mostly maple seeds) (RWC) 1 female; same data except: 7.VI.2005, R.P. Webster coll., margin of river in flood debris (RWC) 1 male; same data except: Keswick River at Rt. 105, (45.9943ํN, $\left.66.8337^{\circ} \mathrm{W}\right), 18 . \mathrm{VI} .2004$, R.P. Webster, river margin on clay sand mix on steep bank (splashing) (LFC) 1 male; Kouchibouguac N.P., 17.IX.1977, J.M. Campbell, Code5977W (CNC) 1 male, 1 sex?; S.J. Miller, Code-6003W (CNC) 1 male, 3 sex?; (LFC) 1 female; A. Smetana, Code-5978W (CNC) 3 males, 1 sex?; 18.IX.1977, J.M. Campbell, Code-59840 (CNC) 1 sex?. Northwest Territories: Ft. Simpson, 9.VI.1972, A. Smetana (CNC) 3 males, 1 female, 3 sex?; (LFC) 1 female, 1 sex?; 10.VI.1972, A. Smetana (CNC) 3 males, 4 females, 3 sex?; 14.VI.1972, A. Smetana (CNC) 1 sex?; Ft. Simpson, Harris Riv., 10.VI.1972, A. Smetana (CNC) 1 sex?; 15.VI.1972. A. Smetana (CNC) 1 female, 1 sex?; Ft. Simpson, Manners Cr., 11.VI.1972, A. Smetana (CNC) 1 female; Hwy 3.5 mi. SE Ft. Simpson, 17.VI.1972, A. Smetana (LFC) 1 sex?. Ontario: 3 mi. S. Richmond, 2.VII.1878, wet ground calcar. bog, D. Maddison (CNC) 1 sex?; (LFC) 1 female; Ottawa, Mer Bleue bog, 3.VIII.1982, A. Davies (CNC) 1 sex?; 11.VIII.1982 (CNC) 1 sex?; St. Lawrence Island N.P., Grenadier I. Center, 26.V.1975, J.M. Campbell, Code-1-27A (LFC) 1 female; 27.V.1974, A. Davies, Code-1-430 (CNC) 1 sex?; (LFC) 1 female; 27.V.1975, A. Smetana, Code-1-455 (CNC) 1 sex?; 27.V.1975, A. Davies, Code-1-40N (LFC) 1 male. Québec: Gatineau, Gatineau Park, Taylor Lk., 06.IX.1973, Smetana \& Davies (CNC) 1 female; Pt. Gatineau, 18-19. VI.1974, A. \& Z. Smetana (CNC) 1 female; (LFC) 1 sex?; Montréal, 19.VIII.1974, E.J. Kiteley (CNC) 2 sex?; 28.VIII.1972 (CNC) 1 sex?. Saskatchewan: Prince Albert N.P., 24.VII.1972, D.E. Bright (CNC) 1 female, 1 sex?

\section{A8. Gnypeta crebrepunctata (Casey)}

\section{Non-type material}

UNITED STATES: California: San Luis Obispo, 25.IX.1950, Cambria Pines Elo, Ian Moore (CNC) 2 males, 1 female; Santa Cruz, 28.IX.1950, Ian Moore (CNC) 1 female. CANADA: British Columbia: Queen Charlotte Islands, $1 \mathrm{~km} \mathrm{~W}$ Moresby Camp, Pallant Cr., 3.VIII.1983, Gravel along edge of creek, J.M. Campbell, 83-51 (LFC) 1 female; Tlell R., end Richardson Rd., 17.VII.1983, Rotting Boletus, J.M. Campbell, 84-14 (CNC) 2 males, 1 female; (LFC) 1 male, 1 female. 


\section{A9. Gnypeta dentata Klimaszewski, sp. nov.}

\section{Paratypes}

CANADA: Alberta: Kananaskis, F.E.S., 1.VIII.1971, J.M. \& B.A. Campbell (CNC) 1 male; Gull Lake, 2.VI.1968, J.H. Franks (LFC) 1 male. Northwest Territories: Unnamed Lake, 18 mi. NW Inuvik via East Channel, 26.VI.1972, A. Smetana (CNC) 1 male; Unnamed Lake, 18 mi. NW Inuvik via East Channel, 26.VI.1972, A. Smetana. PARATYPE (CNC) 1 male, 3 females, 1 sex? (LFC) 1 male; Inuvik, 1.VII.1972, A. Smetana (CNC) 1 female; (LFC) 1 female; 25.VI.1972 (CNC) 4 males, 1 female; (LFC) 1 male; Caribou Hills, Reindeer Sta., 2.VII.1972, A. Smetana, (CNC) 1 female; Ford Lake, N. end of Ford Lake, 23.VI-4.VII.1966, E. Shewell (CNC) 1 male. Saskatchewan: Prince Albert N.P., 24.VII.1972, D.E. Bright (CNC) 1 male.

\section{A10. Gnypeta groenlandica Lohse}

UNITED STATES: Alaska: North Slope, Sadlerochit River, $7 \mathrm{~km}$ from mouth, 6.VIII.1980, R.E. Nelson (CNC) 1 female; Titaluk R. (69² $\left.42^{\prime} \mathrm{N}, 155^{\circ} 12^{\prime} \mathrm{W}\right), 2-7$. VII.1979, R.E. Nelson (CNC) 1 male; Umiat, 10.VIII.1959, Salix sp., R. Madge (CNC) 1 female. DENMARK: Greenland: Nedre Midsommer Sö, Can. Peary Land Expd., 2.VII.1966 (CNC) 1 male; 2.VII.1966, (CNC) 1 male, 1 female, 7 sex?; (LFC) 1 sex?; 3.VIII.1966 (CNC) 1 sex?; 6.VII.1966 (CNC) 1 female, 6 sex?; 10.VII.1966 (CNC) 3 males, 1 female, 6 sex?; 11.VII.1966 (CNC) 1 sex?; 12.VI.1966 (CNC) 1 male, 2 females, 6 sex?; 14.VII. 1966 (CNC) 2 males, 1 female, 4 sex?; 16.VI.1966 (CNC) 1 female, 8 sex?; 20.VI.1966 (CNC) 2 females, 1 male, 6 sex?; 22.VII.1966 (CNC) 5 sex?; 24.VI.1966 (CNC) 1 male, 1 female, 11 sex?; 25.VI.1966 (CNC) 1 female, 2 sex?; 26.VII.1966 (CNC) 1 male, 1 female, 3 sex?; 28.VI.1966 (CNC) 2 males, 16 sex?. CANADA: Manitoba: Churchill, 10.VII.1937, W.J. Brown (CNC) 1 male; 26.VII.1937 (CNC) 1 female. Nunavut: Axel Heiberg Island $\left(79^{\circ} 25^{\prime} \mathrm{N}, 90^{\circ} 45^{\prime} \mathrm{W}\right)$ H.K. Rutz, 4.VIII.1963, Trap 1 (CNC) 1 female; 8.VIII.1963, Trap 1 (CNC) 2 males; 10.VIII.1963 (CNC) 1 female, 3 males; (LFC) 3 males; 14.VIII.1963 (CNC) 1 male, 3 females; 16.VIII.1963, Trap 1 (CNC) 1 sex?; 19.VIII.1963 (CNC) 1 female, 2 sex?; (LFC) 1 female; 20.VIII.1963 (CNC) 1 sex?; 23.VII.1963, Trap 1 (CNC) 1 sex?; 25.VII.1963 (CNC) 1 female, 3 males, 3 sex?; (LFC) 1 sex?; 27.VII.1963, Trap 1. PARATYPE (CNC) 1 male; Eureka $\left(80^{\circ} 09^{\prime} \mathrm{N}, 86^{\circ} 00^{\prime} \mathrm{W}\right), 2 . V I I I .1963$, J.R. Vockeroth (CNC) 1 female; Ellesmere Island,

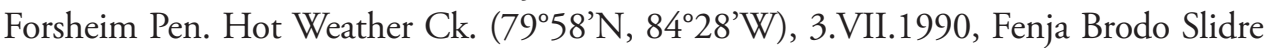
R. (CNC) 1 female; 4.VII.1990, Fenja Brodo (CNC) 1 female; 14.VII.1990 (CNC) 1 male, 1 female; 22.VI.1990 (CNC) 1 male; Forsheim Pen., Slidre Fjord, $1100 \mathrm{ft}$. $\left(80^{\circ} 04^{\prime} \mathrm{N}, 85^{\circ} 36^{\prime} \mathrm{W}\right), 30$.VII.1953, In crown of Geum rossii, P.F. Bruggemann (CNC) 1 female; Hazen Camp, 19.VII.1963, Trap 1, R.E. Leech (LFC) 1 male. Yukon: Komakuk Beach $\left(69^{\circ} 36^{\prime} \mathrm{N}, 140^{\circ} 10^{\prime} \mathrm{W}\right), 05 . V I I .1984$, J.M. Campbell (CNC) 1 female; 15.VI.1984 (CNC) 1 male; Clarence Lagoon $\left(69^{\circ} 38^{\prime} \mathrm{N}, 140^{\circ} 55^{\prime} \mathrm{W}\right), 05 . V I I .1984$, sifting litter on shore, J.M. Campbell (CNC) 1 female; (LFC) 1 male. 


\section{A11. Gnypeta helenae Casey}

\section{Non-type material}

UNITED STATES: New Mexico: Truth or Consequences, 29.VII.1954, Ian Moore (CNC) 1 female. CANADA. Alberta: Waterton Lk. N.P., Belly R., Chef Mt. Hwy., 4500', 18.VI.1980, J.M. Campbell (CNC) 1 male. British Columbia: 19.VI.1957, G. Stace Smith (LFC) 1 female; 13 mi. W. Osoyoos, 5.VI.1968, Campbell \& Smetana (CNC) 1 male; Creston, 9.X.1956, G. Stace Smith (LFC) 1 male; 8. mi. W. Creston, 10.VI.1968, Campbell \& Smetana (CNC) 1 female; Peachland, 27.VII.1919, J.B. Wallis (CNC) 1 female; West Creston, banks Kootenay R. ( $\left.49^{\circ} 11^{\prime} \mathrm{N}, 116^{\circ} 38^{\prime} \mathrm{W}\right)$, 28.VIII.1980, silt around Typha, I. Askevold (LFC) 1 male; Wynndel, Kootenay Lake, 14.VIII.1982, R. Baranowski, BWRS (MZL) 4 males, 3 females.

\section{A12. Gnypeta lohsei Klimaszewski, sp. nov.}

\section{Paratypes}

UNITED STATES: Alaska: Prudhoe Bay Rd. Bonanza Cr., 900'(6640’N, 15040’W), 2.VII.1978, A. Smetana \& J.M. Campbell (CNC) 1 female. Washington: Olympic N.P., Obstruction Peak, 6000', 10.VIII.1979, J.M. \& B.A. Campbell (CNC) 1 male, 5 females, 2 sex?; (LFC) 1 male, 1 female. CANADA: Alberta: Bruderheim, 1.VII.1982, A. Davies, tread Carex and moss (LFC) 1 female; Kananaskis F.E.S., 01.VIII.1972, J.M. \& B.A. Campbell (CNC) 1 male, 1 sex?; Highwood Pass, 7600', 2.VIII.1971, J.M. \& B.A. Campbell (CNC) 1 female; Highwood Pass, 35 mi. S. Kananaskis F.E.S., 7800', 19.VII.1971, J.M. \& B.A. Campbell (CNC) 3 females, 5 sex?; (LFC) 1 female; 20 mi. SW Kananaskis F.E.S., Snow Ridge, 7000', 31.VII.1971, J.M. \& B.A. Campbell (CNC) 4 sex?; Banff N.P., Helen Lk., 7800', 11.VIII.1971, J.M. \& B.A. Campbell (CNC) 4 males, 2 females, 34 sex?; (LFC) 3 males, 1 female; Banff N.P. Ptarmigan Lk., 7500', 13.VIII.1971, J.M. \& B.A. Campbell (CNC) 3 males, 9 sex?; Banff N.P., Redoubt Lk, 7800', 13.VIII.1971, J.M. \& B.A. Campbell (CNC) 1 female, 1 sex?; Banff N.P., Eiffel Lk., 7400', 18.VII.1971, J.M. \& B.A. Campbell (CNC) 1 sex?; Waterton Lk. N.P., Upper Rowe Lk., 7100', 20.VI.1980, J.M. Campbell (CNC) 1 male, 1 sex?; Waterton Lk. N.P., Crypt Lake, 6500', 22.VI.1980, J.M. Campbell (CNC) 1 sex?; Waterton Lk. N.P., Mi. 3 Red Rock Cny. Rd., 4400', 26.VI.1980, J.M. Campbell (CNC) 1 sex?. British Columbia: Garibaldi Prov. Pk., Paul Ridge, 5400', 4.VIII.1975, J.M. \& B.A. Campbell (LFC) 1 female; Garibaldi Prov. Pk., Diamond Head Tr., 4000-4500', 19.VII.1973, A. \& Z. \& D. Smetana (CNC) 2 males, 1 female, 2 sex?; 26.VII.1973 (CNC) 1 sex?; Revelstoke N.P, Mt. Revelstoke, 6500', 18.VIII.1971, J.M. \& B.A. Campbell (CNC) 1 male, 1 female, 1 sex?; Revelstoke N.P, Jade Lk., 6000', 19.VIII.1971, J.M. \& B.A. Campbell (CNC) 1 male, 3 sex?; (LFC) 1 female; Revelstoke N.P, Millar Lks, 6300', 19.VIII.1971, J.M. \& B.A. Campbell (CNC) 3 sex?; Manning Prov. Pk., 20 mi. E. Hope, 21.VI.1968, Campbell \& Smetana (CNC) 1 sex?; Manning Prov. Pk., Derek Falls, 4000', 26.VII.1975, J.M. 
\& B.A. Campbell (CNC) 1 female; Manning Prov. Pk., Three Brothers Mt., 7000', 27.VII.1975, J.M. \& B.A. Campbell (CNC) 1 sex?; Manning Prov. Pk., Mt. Frosty, 7200', 29.VII.1975, J.M. \& B.A. Campbell (CNC) 1 female; Manning Prov. Pk., Mt. Frosty, 6100', 30.VII.1975, J.M. \& B.A. Campbell (CNC) 1 male, 5 females, 2 sex?; Mt. Copeland, 6500', 27.VIII.1971, J.M. Campbell (CNC) 4 males, 8 sex?; Mt. Begbie, 6200', 28-30.VIII.1971, J.M. Campbell (CNC) 1 female, 2 sex?; Mt. Begbie, 7000', 29.VIII.1971, J.M. Campbell (CNC) 1 female, 2 sex?.

\section{A13. Gnypeta nigrella (LeConte)}

\section{Non-type material}

UNITED STATES: Pennsylvania: Easton, 13.V.1915, 5702 (CNC) 1 female. Vermont: Manchester, 3.VII.1935 (CNC) 1 male, 1 female. CANADA: New Brunswick: Charlotte Co., near New River $\left(45.21176^{\circ} \mathrm{N}, 66.61790^{\circ} \mathrm{W}\right), 2 . V I .2006$, R.P. Webster, mixed forest, margin of vernal pond in moist leaf litter (RWC) 1 female; Restigouche Co., Little Tobique River near Red Brook ( $\left.47.4465^{\circ} \mathrm{N}, 67.0689^{\circ} \mathrm{W}\right), 13$. VI.2006, R.P. Webster, river margin on sand (RWC) 1 male; Sunbury Co., Sheffield, Portobello Creek N.W.A. $\left(45.8952^{\circ} \mathrm{N}, 66.2728^{\circ} \mathrm{W}\right), 18$. II.2004, R.P. Webster, silver maple forest, black light trap near marsh (RWC) 1 male; Carleton Co. Hartland, Middle

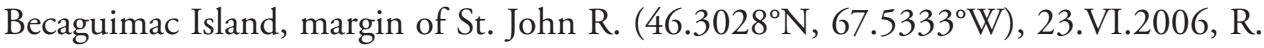
Capozi \& R. Webster, among cobblestones near water (RWC) 1 male; York Co., Fredericton, at St. John River $\left(45.9588^{\circ} \mathrm{N}, 66.6254^{\circ} \mathrm{W}\right)$, 4.VII.2004, R.P. Webster, margin of river, in drift material (mostly maple seeds) (RWC) 1 male; York Co., Kingsclear Mazerolle Settlement $\left(45.8729^{\circ} \mathrm{N}, 66.8311^{\circ} \mathrm{W}\right)$, 28.IV.2006, R.P. Webster, margin of stream (sun exposed), in fine gravel/sand, near water (RWC) 1 sex?

\section{A14. Gnypeta sellmani Brundin}

\section{Non-type material}

UNITED STATES: Alaska: Alaska Range, Antimony Cr., 2.5 mi. E mi. 181 G. Parks Hwy, 3500', 27.VI.1978, Smetana \& Becker (CNC) 1 male; Kenai Pen. 1 mi. Anchor Pt., 200', 2.VI.1978, Smetana \& Becker (CNC) 2 males; (LFC) 2 females; Kenai Pen. Anchor R. at Hwy. 1, 450', 4.VI.1978, Smetana \& Becker (CNC) 1 female; (LFC) 1 female; Kenai Pen., 3 mi. SE Kenai, 7.VI.1978, Smetana \& Becker (CNC) 1 male, 1 sex?; Prudhoe Bay Rd. Bonanza Cr., 900’ (66²0’N, 15040’W), 2.VII.1978, A. Smetana \& J.M. Campbell (CNC) 1 male, 1 female; Prudhoe Bay Rd. 2 mi. S Grayling Lk., 1300' (665 $\left.55^{\prime} \mathrm{N}, 150^{\circ} 25^{\prime} \mathrm{W}\right)$, 9.VII.1978, Smetana \& Campbell (CNC) 2 males, 3 females, 1 sex?; Mi. 23 Taylor Hwy., 8.VII.1968, Campbell \& Smetana (CNC) 1 male; Mi. 43 Taylor Hwy., 8.VII.1968, Campbell \& Smetana (CNC) 1 male; 4 mi. SE North Pole, 30.VI.1978, A. Smetana \& J.M. Campbell (CNC) 1 male. CANADA: Northwest Territories: Inuvik, 1.VII.1972, A. Smetana (CNC) 2 females; (LFC) 1 male; 
24.VI.1972, A. Smetana (CNC) 1 male, 2 females; (LFC) 1 male, 1 sex?; 25.VI.1972, A. Smetana (CNC) 5 males, 12 females, 1 sex?; Shell Lake, 27.VI.1972, A. Smetana (CNC) 2 males, 6 females, 1 sex?; (LFC) 1 female, 1 sex?; Boot Lake, 28.VI.1972, A. Smetana (CNC) 2 males, 1 female; Yellowknife, 20.V.1953, J.G. Chillcott (CNC) 1 female; Unnamed Lake, 18 mi. NW Inuvik via East Channel, 26.VI.1972, A. Smetana (CNC) 3 males, 3 females. Manitoba: Churchill, 13.VI.1951, J.G. Chillcott (CNC) 1 male, 1 female; 17.VI.1952 (CNC) 1 male. Québec: Gaspésie, Parc Gaspésie, Mont Albert, 3700', 10-11.VII.1972, J.M. Campbell (CNC) 2 males, 1 sex?; Gaspésie, Parc Gaspésie, Mont Jacques Cartier, 4000', 22.VII.1972, J.M. Campbell (CNC) 1 male, 1 female, 2 sex ?; (LFC) 1 female. Saskatchewan: Prince Albert N.P., 24.VII.1972, D.E. Bright (CNC) 1 female. Yukon: British Mts. Fish Creek, $200 \mathrm{~m}\left(69^{\circ} 27^{\prime} \mathrm{N}, 140^{\circ} 23^{\prime} \mathrm{W}\right)$, 3.VII.1984, in moss in water in polygon channels, J.M. Campbell, 84-52 (CNC) 1 male; British Mts. Fish Creek, $180 \mathrm{~m}\left(69^{\circ} 27^{\prime} \mathrm{N}, 140^{\circ} 19^{\prime} \mathrm{W}\right)$, 3.VII.1984, treading edge of temporary pond, J.M. Campbell, 84-48 (CNC) 1 female; British Mts., Swan Pond, $4 \mathrm{~km}$ NE Wolf Cr, $340 \mathrm{~m}\left(69^{\circ} 08^{\prime} \mathrm{N}, 140^{\circ} 14^{\prime} \mathrm{W}\right)$, 23.VI.1984, treading sedges around edge of pond, J.M. Campbell, 84-25a (CNC) 1 male; Mile 237 Dempster Hwy, 4.VII.1979, B.F. \& J.L. Carr, Lot 2 (CNC) 1 male, 1 female; Dempster Hwy mi. 65, 3300', 13.VII.1968, J.M. Campbell \& A. Smetana (CNC) 9 males, 4 females, 3 sex?; Dempster Hwy. Mi. 152.5, 1900', 20.VII.1978, A. Smetana \& J.M. Campbell (LFC) 1 male; Dempster Hwy mi. 136, 1900', 22.VII.1978, J.M. Campbell \& A. Smetana (CNC) 2 females; Dempster Hwy mi. 53, 4200', 24.VII.1978, A. Smetana \& J.M. Campbell (CNC) 1 male; 11 mi. W. Elsa, 18.VII.1968, J.M. Campbell \& A. Smetana (CNC) 1 male.

\section{A15. Gnypeta uteana (Casey)}

\section{Non-type material}

CANADA. Alberta: Banff N.P., Bow Pass, 6800', 10.VIII.1971, J.M. \& B.A. Campbell (CNC) 1 female, 2 sex?; (LFC) 1 female, 1 sex?; Banff N.P., Mt. Temple Ski Lodge, 6600', 12.VIII.1971, J.M. Campbell (CNC) 1 male; Marmot Creek, $10 \mathrm{mi}$. SW Kananaskis F.E.S., 5000', 15.VIII.1971, J.M. Campbell (CNC) 2 females; Highwood Pass, 35 mi. S. Kananaskis F.E.S., 7800', 19.VII.1971, J.M. \& B.A. Campbell (LFC) 1 male. 